Florida International University FIU Digital Commons

$7-12-2010$

\title{
Characterization of Oscillatoria spp. and their Role in Black Band Disease of Coral
}

Dina Stanic

Florida International University, dina.stanic@gmail.com

DOI: $10.25148 /$ etd.FI10080901

Follow this and additional works at: https://digitalcommons.fiu.edu/etd

Cart of the Life Sciences Commons

\section{Recommended Citation}

Stanic, Dina, "Characterization of Oscillatoria spp. and their Role in Black Band Disease of Coral" (2010). FIU Electronic Theses and Dissertations. 243.

https://digitalcommons.fiu.edu/etd/243

This work is brought to you for free and open access by the University Graduate School at FIU Digital Commons. It has been accepted for inclusion in FIU Electronic Theses and Dissertations by an authorized administrator of FIU Digital Commons. For more information, please contact dcc@fiu.edu. 


\section{FLORIDA INTERNATIONAL UNIVERSITY}

Miami, Florida

CHARACTERIZATION OF OSCILLATORIA SPP. AND THEIR ROLE IN BLACK BAND DISEASE OF CORAL

A thesis submitted in partial fulfillment of the

requirements for the degree of

MASTER OF SCIENCE

in

BIOLOGY

by

Dina Stanic 
To: Dean Kenneth Furton

College of Arts and Sciences

This thesis, written by Dina Stanic, and entitled Characterization of Oscillatoria spp. and their Role in Black Band Disease of Coral, having been approved in respect to style and intellectual content, is referred to you for judgment.

We have read this thesis and recommend that it be approved.

Miroslav Gantar

John Makemson

Laurie L. Richardson, Major Professor

Date of Defense: July 12, 2010

The thesis of Dina Stanic is approved.

\begin{tabular}{r}
$\begin{array}{r}\text { Dean Kenneth Furton } \\
\text { College of Arts and Sciences }\end{array}$ \\
\hline Interim Dean Kevin O’Shea \\
University Graduate School
\end{tabular}

Florida International University, 2010 


\section{ABSTRACT OF THE THESIS \\ CHARACTERIZATION OF OSCILLATORIA SPP. AND THEIR ROLE IN BLACK BAND DISEASE OF CORAL}

by

Dina Stanic

Florida International University, 2010

Miami, Florida

Professor Laurie L. Richardson, Major Professor

Black band disease (BBD) is a cyanobacterial dominated pathogenic consortium that affects corals worldwide. Recently two cyanobacteria (Oscillatoria strains 101-1 and 100-1) were isolated into culture from BBD. The aim of this study was to characterize the strains and assess their role in BBD pathogenesis. Light, scanning electron and transmission electron microscopy, coupled with 16S rRNA gene sequencing, were used for taxonomic characterization. Cyanotoxin production was assessed by enzyme-linked immunosorbent assay. Toxin identification was performed by high performance liquid chromatography. The ability of the strains to initiate BBD was tested on host coral fragments of Siderastrea siderea and Diploria strigosa under controlled laboratory conditions. Results showed that both Oscillatoria sp. strains caused infection that resulted in complete lysis of coral tissue. Both strains produced a cyanotoxin, identified as microcystin-LR, with production affected by different environmental factors. This study provides evidence that BBD Oscillatoria is a key component in BBD pathogenicity. 


\section{TABLE OF CONTENTS}

CHAPTER

PAGE

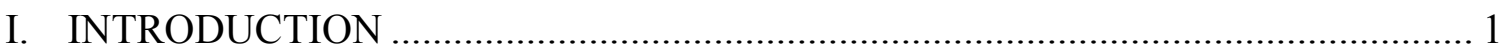

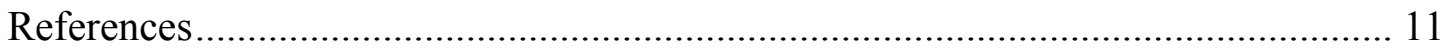

II. CHARACTERIZATION OF OSCILLATORIA SP. FROM CARRIBEAN BLACK

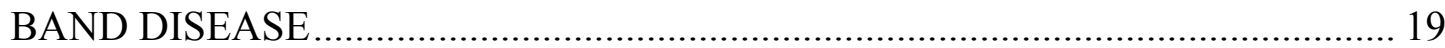

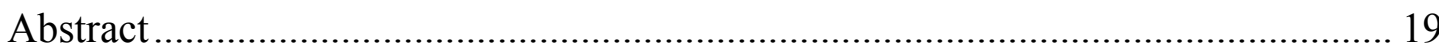

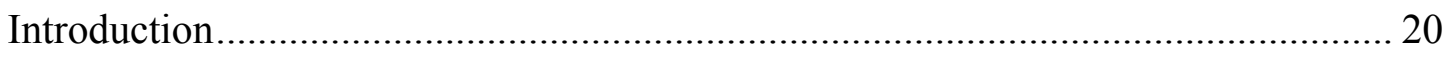

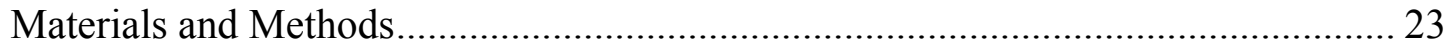

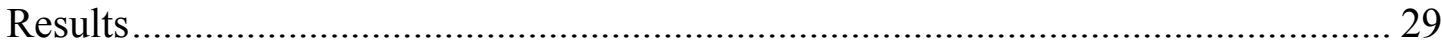

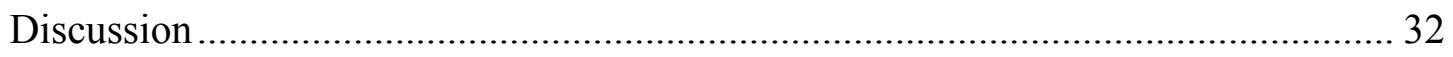

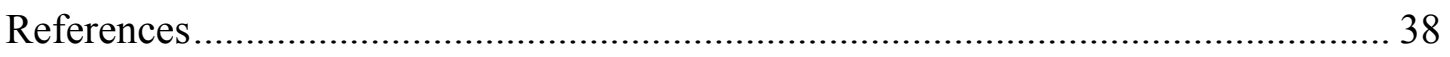

III. MICROCYSTIN PRODUCTION AND ECOLOGICAL PHYSIOLOGY OF THE CARIBBEAN BLACK BAND DISEASE CYANOBACTERIUM OSCILLATORIA

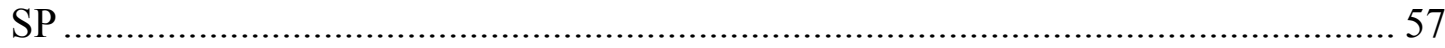

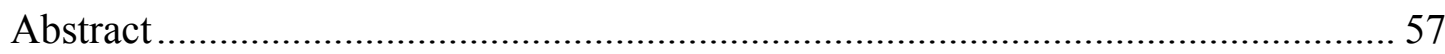

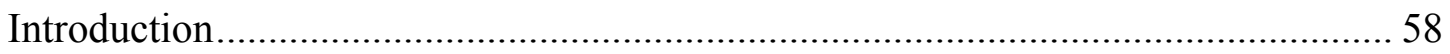

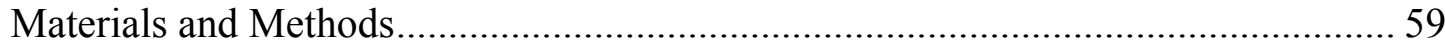

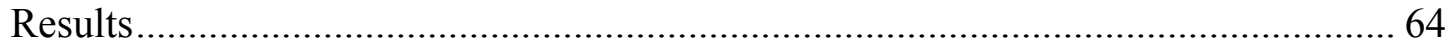

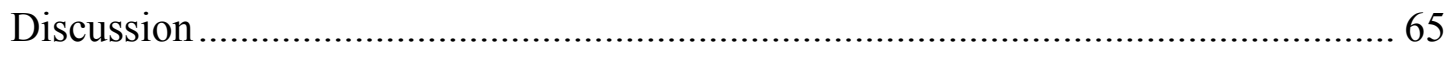

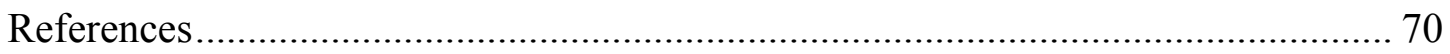

IV. IS OSCILLATORIA SP. THE PRIMARY PATHOGEN OF BLACK BAND

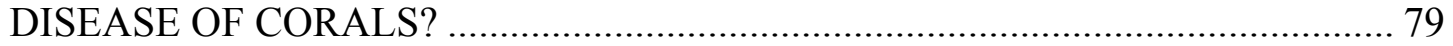

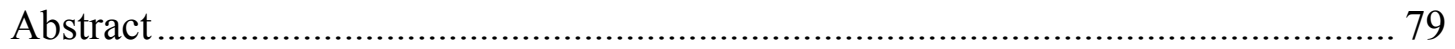

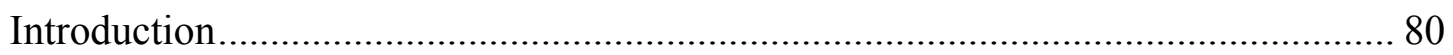

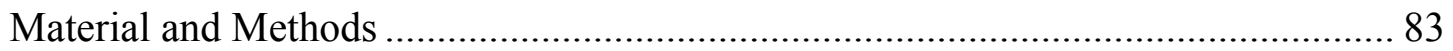

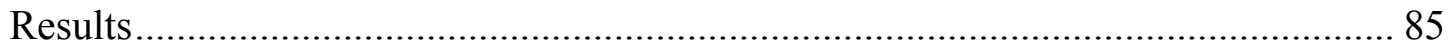

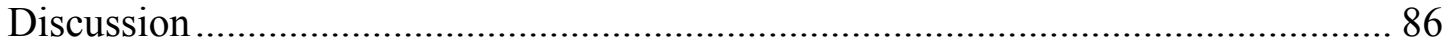

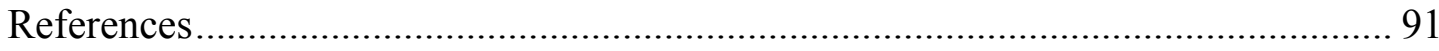

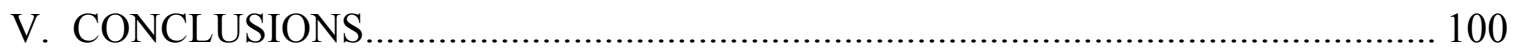

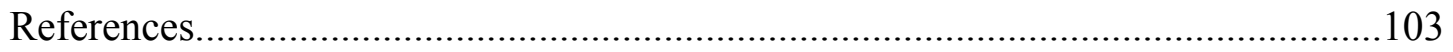




\section{LIST OF TABLES}

TABLE

PAGE

\section{CHAPTER II}

Table 1. Black band disease cyanobacteria isolated into culture and used in this study...49

Table 2. Bacteria isolated from the culture liquid of Oscillatoria $100-1 \ldots \ldots \ldots \ldots \ldots . . . . .50$

Table 3. Bacteria isolated from the culture liquid of Oscillatoria $101-1 \ldots \ldots \ldots \ldots \ldots . . . .50$

Table 4. Comparison of the two Oscillatoria strains from this study with the newly described Pseudoscillatoria coralii (FJ210722.2) (Rasoulouniriana et al. 2009)

\section{CHAPTER III}

Table 1. BBD cyanobacterial isolates investigated in this study

Table 2. Mean microcystin-LR equivalents produced in BBD cyanobacterial cultures based on cell extracts and ELISA...............................................76 


\section{LIST OF FIGURES}

FIGURE

PAGE

\section{CHAPTER II}

Figure 1. Scanning electron micrographs of Oscillatoria strains 100-1 (A) and 101-1 (B) showing filamentous, non-heterocystous, and unbranched trichomes that are $3.5 \mu \mathrm{m}$ wide and $3.5 \mu \mathrm{m}$ long

Figure 2. Photomicrographs of Oscillatoria strains 100-1 (A) and 101-1 (B) trichomes with tapering and rounded ends...

Figure 3. Transmission electron micrographs of Oscillatoria strains 100-1 (A) and 101-1 (B) showing radial thylakoid arrangement (T) and thick sheath layer (SL)

Figure 4. Pigment spectra of Oscillatoria strains 100-1 (A) and 101-1 (B) showing two maximum absorbance peaks at 565 and $548 \mathrm{~nm}$

Figure 5. Effect of different $\mathrm{pH}$ values on growth of Oscillatoria strains 100-1 (A) and 101-1 (B)

Figure 6. Differences in growth pattern with varying $\mathrm{pH}$ of Oscillatoria strains 101-1 (A) and 100-1 (B).

Figure 7. Representative LH-PCR profiles obtained from the cultures of Oscillatoria

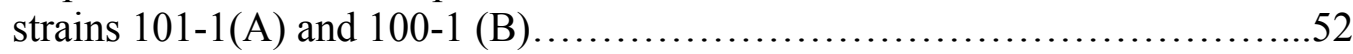

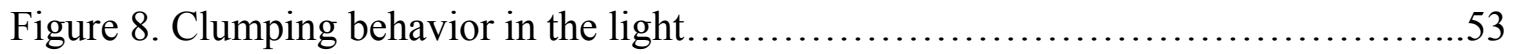

Figure 9. Relative clumping activity (decrease in area from $t=0$ ) of strains that exhibited the ability to form clumps (Figure 8 )...................... 54

Figure 10. Clumping behavior in the dark .........................................

Figure 11. Phylogenetic tree derived from the 16S rRNA gene sequence of Oscillatoria strain 100-1 and its most closely related neighbors

\section{CHAPTER III}

Figure 1. UPLC-MS/MS separation of a standard mix of cyanotoxins of interest.......... 76

Figure 2. UPLC-MS/MS trace analysis of a cell extract of Oscillatoria strain 101-1 (B) 
showing a positive identification of MC-LR as compared to a standard (A) of purified MC-LR ...................................................... 77

Figure 3. Effect of environmental factors on growth (bars) and production of MCequivalent (filled circles) by Oscillatoria strain 101-1

\section{CHAPTER IV}

Figure 1. Oscillatoria strain 101-1 on a coral fragment of Diploria strigosa

Figure 2. Oscillatoria strain 100-1 on a coral fragment of Siderastrea siderea.

Figure 3. SEM of a freeze fractured fragment of Siderastrea siderea showing microbial growth three weeks after infection with Oscillatoria strain 100-1 .... 97

Figure 4. White appearance of the cyanobacterial patch seen during and after the dark cycle was presumably formed by species from the genus Baggiatoa

Figure 5. Photomicrograph of filaments of Beggiatoa sp. and Oscillatoria sp. in the patch formed after infection with Oscillatoria strain 100-1....

Figure 6. Back scatter image of filamentous microorganisms within cyanobacterial patch 


\section{CHAPTER I. \\ INTRODUCTION}

\section{Coral Reefs}

Coral reefs support a high diversity of marine species that depend on corals for their survival. They are also economically important for the tourist and fishing industries (Hughes, 1994; Harvell et al., 1999). Recent findings show that coral reefs are in severe decline. Estimates suggest that $27 \%$ of coral cover worldwide has been lost, with another $16 \%$ at serious risk; some Caribbean reefs have experienced up to an $80 \%$ decline in coral cover (Wilkinson, 2002; Gardner et al., 2003). Reduction in coral cover is caused by abiotic factors (temperature stress, sedimentation, nutrients, ultraviolet radiation) and biotic factors (predation, overgrowth of algae, infectious diseases) (Harvell et al., 2007). Climate change is also among the factors that may lead to extinction of coral reefs, and by one recent estimate, nearly one third of reef building corals face an elevated extinction rate (Carpenter et al., 2008). During the last century global temperature increased $0.6 \pm$ $0.2{ }^{\circ} \mathrm{C}$, and the prediction is that it will further increase for another 1.5 to $4.5^{\circ} \mathrm{C}$ during the next century (Sokolow, 2009). At the same time atmospheric $\mathrm{CO}_{2}$ concentrations have increased 100 ppm compared with preindustrial levels (Bindoff et al., 2007; Rosenberg et al., 2007), the global mean sea level has been rising over the last century, and global oceanic $\mathrm{pH}$ has dropped approximately $0.1 \mathrm{pH}$ units since 1750 (Bindoff et al., 2007). All of these factors contribute to the reduction of coral cover worldwide. Among them coral diseases are proposed to be a major cause for the recent decline in coral cover (Hughes, 1994; Aronson and Precht, 1997; Aronson and Precht, 2001; Weil, 2004). 


\section{Coral Diseases}

Coral diseases are a major cause for the decline of coral reefs worldwide (Dustan, 1999; Porter et al., 2001; Harvell et al., 1999). In the Caribbean, where only eight percent of all coral reefs (by area) are found (Spalding and Greenfell, 1997), over 70\% of all disease/syndrome reports originate (Harvell et al., 2007). For this reason the Caribbean region is known as a disease 'hotspot' (Harvell et al., 2007).

The first Caribbean coral diseases were reported in the 1970s (Antonius, 1973; Garret and Ducklow, 1975; Dustan 1977; Gladfelter et al., 1977). Today there are approximately 30 coral diseases and syndromes proposed (Richardson, 1998; Green and Bruckner, 2000; Sutherland et al., 2004; Weil, 2004), which together affect more than 150 species of corals worldwide (Sutherland et al., 2004; Wilkinson, 2004). Potential pathogens are still unknown for most of the coral diseases. For seven of the most commonly found coral diseases, potential pathogens have been identified, however Koch's postulates have only been fulfilled for five of them (Harvell et al., 2007). The pathogen for white plague type II was identified as Aurantimonas coralicida (Richardson et al., 1998). This pathogen has been isolated from white plague type II infections in Florida Keys, the Virgin Islands, and Dominica (Richardson and Aronson, 2002). Aspergillosis is a disease that affects gorgonians and is caused by the fungus Aspergillus sydowii (Smith et al., 1996; Geiser et al., 1998). The pathogen for white pox has been identified as Serratia marcescens (Patterson et al., 2002). Bacterial bleaching of Oculina patagonica is caused by Vibrio shiloii (Kushamaro et al., 1997) and of Pocillopora damicornis by Vibrio coralliilyticus (Ben Haim et al., 2003). In the case of bacterial bleaching, infection is temperature related, and virulence factors are expressed at $29^{\circ} \mathrm{C}$ in 
laboratory cultures (Rosenberg et al., 1999; Banin et al., 2000). This is in agreement with the documented increasing levels of bleaching at high seawater temperature on reefs (Brown et al., 1996; Brown et al., 1997). It appears that some diseases can be caused by a single organism while others by complex consortia of microorganisms. For example, black band disease appears to contain at least 50 different bacterial types (Sekar et al., 2006).

The number of coral host species affected by each disease varies according to geographic location. For example it has been shown that white plague type II has the widest host range in the Caribbean and black band disease has the widest host range in the Indo-Pacific (Dinsdale, 2002; Sutherland et al., 2004; Weil et al., 2006). Similarly, the prevalence of each coral disease varies with respect to geographic location, as well as temporally and with respect to coral host species (Kuta and Richardson, 1997;

Richardson et al., 1998; Dinsdale, 2002; Kim and Harvell, 2002; Richardson and Voss, 2005).

Some coral diseases, such as black band disease, white band disease, and white plague, cause coral tissue lyses as the disease progresses over the coral colony. The progression of the disease leads to either partial or complete death of the colony, leaving bare coral skeleton which can be colonized by algae (Edmunds, 1991; Kuta, 2000).

Little is known about the mechanisms of dispersal and spread of coral diseases (Richardson, 1998). It is extremely difficult to follow pathogens through the environment in order to determine their reservoirs and modes of transmission (Harvell et al., 2007). Biofilms in reef sediments were found to contain non-pathogenic aggregates of the black band disease community, and were identified as disease reservoirs for this disease 
(Carlton and Richardson, 1995). Atmospheric African dust has been suggested to contain spores of the fungus Aspergillus sydowii and is proposed as the disease reservoir for aspergillosis (Shinn et al., 2000). The only two coral disease vectors identified are the fireworm Hermodice carunculata and damselfish. In these cases the gut of Hermodice carunculata contains Vibrio shiloi, a pathogen that induces bacterial bleaching in Mediterranean coral (Sussman et al., 2003), and damselfish harbor one life history stage of a digenean (trematode) that infects Porites (Aeby and Santavy, 2006).

\section{Black Band Disease}

Black band disease (BBD) affects corals worldwide and contributes to coral reef decline (Carlton \& Richardson, 1995). Black band disease was first documented in 1973 in the Florida Keys and Belize (Antonius, 1973). Since then this disease has been found on reefs throughout the Caribbean (Garrett and Ducklow, 1975; Rützler et al., 1983; Peters 1993; Garzón-Ferreira et al., 2001; Kuta and Richardson, 1996; Voss and Richardson, 2006), the Indo-Pacific (Antonius, 1985; Page and Willis, 2006), the Great Barrier Reef (Dinsdale, 1994; Miller, 1996; Dinsdale, 2002; Willis et al., 2004), and the Red Sea (Antonius, 1988). Black band disease is known to destroy key reef-forming coral species and in that way is causes significant changes to the coral reef ecosystem (Edmunds, 1991; Peters, 1993; Bruckner and Bruckner, 1997; Kuta and Richardson, 1997). It affects 19 of 66 Caribbean shallow-water scleractinian species (Rützler et al., 1983; Kuta and Richardson, 1996; Wheaton et al., 2001) and 45 of approximately 400 Indo-Pacific scleractinian species (Antonius, 1985; Miller, 1996; Frias-Lopez et al., 2003). Six Caribbean gorgonian species are also affected (Antonius, 1981; Feingold, 1988). The most susceptible BBD coral host species in the Caribbean are Montastraea 
annularis and Diploria strigosa (Rützler et al., 1983), but other studies have shown that the coral species Colpophyllia natans, Diploria labyrinthiformis, Diploria clivosa, Montastraea cavernosa, Montastraea faveolata, Montastraea franksii and Siderastrea siderea, are also highly susceptible to BBD (Edmunds, 1991; Kuta and Richardson, 1996; Bruckner and Bruckner, 1997; Bruckner et al., 1997; Borger, 2005; Borger and Steiner, 2005; Kaczmarsky et al., 2005; Voss and Richardson, 2006). Black band disease can reinfect the same coral colony (Edmunds, 1991; Kuta and Richardson, 1996), which results in increased mortality rates (Edmunds, 1991).

Black band disease is characterized as a horizontally migrating dark-colored band that ranges in width from $1 \mathrm{~mm}$ to a few centimeters. The band migrates across the tissue of corals at a rate as high as $1 \mathrm{~cm} /$ day killing healthy tissue and leaving behind the dead skeletal surface (Antonius, 1981; Richardson, 1996; Richardson, 1998). The band is dominated by phycoerythrin-rich, gliding, filamentous non-heterocystous cyanobacteria (Antonius 1973; Rützler et al., 1983; Taylor, 1983; Richardson et al., 1997; Richardson and Kuta 2003). In addition to a spatially dominant cyanobacterial population this pathogenic microbial consortium (Richardson, 2004) contains sulfide-oxidizing bacteria, from the genus Beggiatoa (Garrett and Ducklow, 1975; Ducklow and Mitchell, 1979), sulfate reducing bacteria primarily from the genus Desulfovibrio (Cooney et. al., 2002; Viehman et al., 2006), marine fungi (Ramos-Flores, 1983), and numerous heterotrophic bacteria (Cooney at al., 2002; Frias-Lopez et al., 2002; Frias-Lopez et al., 2004; Sekar et al., 2006, Barneah et al., 2007). Heterotrophic bacteria include a wide assortment of proteobacteria, Cytophaga sp., and firmicutes. Within the proteobacteria a member of the $\alpha$-proteobacteria, closely related to the pathogen that causes juvenile oyster disease, is 
often found (Sekar et al; 2006), $\delta$-proteobacteria (including sequences closely related to the genus Desulfovibrio), and $\gamma$-proteobacteria, which contain sulfide oxidizers, are also found (Sekar et al; 2006). According to molecular studies the relative abundances of these bacterial groups, as well as the composition of the BBD microbial community, varies with respect to geographic location and coral host species (Frias-Lopez et al., 2004; Sekar et al., 2006; Voss et al., 2007).

Since the disease was identified many attempts have been made to identify the dominant cyanobacterium in BBD. Originally, the dominant Caribbean BBD cyanobacterium was identified as Oscillatoria submembranacea (Antonius, 1973). It was then reclassified as Phormidium corallyticum based on morphological identification (Rützler and Santavy, 1983). In 1991 a cyanobacterium morphologically identified as $P$. corallyticum was isolated from BBD in the Florida Keys (Richardson and Kuta, 2003), but 16S rRNA gene sequencing revealed that this isolate was more closely related to the genus Geitlerinema (Cooney et al., 2002; Ragoonath, 2005). Myers et al. (2007) isolated cyanobacteria from 29 BBD samples collected from reefs located offshore of Key Largo (Florida), Lee Stocking Island (Bahamas), St. Croix (US Virgin Islands) and Negros Island, (Philippines). They detected, using denaturing gradient gel electrophoresis (DGGE), the presence of cyanobacterial sequence which was related to that of an Oscillatoria sp. in 26 out of 29 BBD field samples. They also confirmed the presence of Geitlerinema sp. in the BBD microbial community, and found one Leptolyngbya- and one Phormidium-related sequence. The $16 \mathrm{~S}$ rRNA gene cloning and sequencing of BBD samples from Barbados and St. Croix, US Virgin Islands revealed the presence of a cyanobacterial sequence that was most closely related to Oscillatoria cf. corallinae, with 
$92 \%$ similarity (Cooney et al., 2002). Cyanobacterial sequences closely related to the Oscillatoria sequence identified in the study by Cooney et al. (2002), and referred to as uncultured BBD Oscillatoria, have been found in the clone libraries of BBD communities from the Florida Keys, the Philippines, the Bahamas and Curaçao (FriasLopez et al., 2002; Sekar et al., 2006; Myers and Richardson, 2009). In the work done in the Indo-Pacific region (Sussman et al. 2006) and the Red Sea (Barneah et al., 2007) researchers found a BBD cyanobacterium $99 \%$ similar to the uncultured BBD Oscillatoria detected in Caribbean BBD. These results have led authors to suggest that the uncultured BBD Oscillatoria may be found in black band disease samples worldwide.

Black band disease infection usually begins on the upper surface of a coral colony as a small dark pigmented patch (Antonius, 1981). The patch forms a ring that migrates horizontally across the coral surface. As the band migrates it lyses coral tissue leaving behind bare skeleton (Antonius, 1981; Carlton and Richardson, 1995). Black band disease may disappear before complete destruction of the coral colony, usually with the onset of lower seawater temperatures (Voss and Richardson, 2006). Infection is a seasonal phenomenon and the activity of BBD is highest during late summer and fall (Antonius, 1981; Edmunds, 1991). However, BBD has been reported year round and at seawater temperatures as low as $19.6^{\circ} \mathrm{C}$ (Kuta and Richardson, 1996).

Some other environmental and physiological stressors may influence the appearance of BBD including terrestrial runoff (Bruckner et al., 1997b; Frias-Lopez et al., 2002), coral overgrowth by algae (Bruckner et al., 1997), and eutrophication (Antonius, 1981; Kuta and Richardson, 2002). 
The BBD microbial community resembles cyanobacterial mat communities from sulfide-rich hot springs and hypersaline ponds because of the presence of dominant filamentous cyanobacteria and a vertically migrating oxygen and sulfide interface (Carlton and Richardson, 1995). However, the BBD mat is different because it is pathogenic and actively degrades coral tissue (Richardson and Kuta, 2003). The oxygen and sulfide interface is a narrow zone of overlapping $\mathrm{O}_{2}$ and $\mathrm{H}_{2} \mathrm{~S}$ with aerobic conditions above the interface and anoxic and sulfide-rich conditions below (Carlton and Richardson, 1995). During the day the cyanobacteria perform oxygenic photosynthesis, producing a supersaturated oxic zone in the top of the band; however this zone contains sulfide at times. The cyanobacteria in BBD can survive the high sulfide environment by performing oxygenic photosynthesis in the presence of sulfide (Richardson and Kuta, 2003; Myers et al., 2007). The base of the band is anoxic and dominated by the sulfatereducing bacteria Desulfovibrio spp. The oxic/anoxic interface contains sulfide-oxidizing bacteria Beggiatoa spp. The interface migrates vertically on a dial basis depending on changes in light intensity (Viehman and Richardson, 2002), and photosynthetic activity within the band (Carlton and Richardson, 1995; Richardson et al., 1997). When low light conditions are present the surface of BBD is dominated by cyanobacteria, but when light intensity increases Beggiatoa spp.migrate to the band surface (Viehman and Richardson, 2002). During the night, since oxygen production is absent, Desulfovibrio spp. undergo sulfate reduction, which increases sulfide concentrations in the band. The result is the presence of sulfide throughout the band during the night and migration of the oxic/anoxic interface to the band surface (Carlton and Richardson, 1995; Richardson et al., 1997). 
Factors that have been proposed to contribute to the pathogenicity of BBD are anoxia and the presence of toxic sulfide in the interior of black band (Carlton and Richardson, 1995). Recently (Richardson et al. 2007; Gantar et al., 2009) showed that cyanobacteria isolated from BBD produce toxins that may also be involved in the pathogenicity of BBD. They found that the cyanobacterial toxin microcystin was present in 22 BBD samples from the Bahamas and Florida Keys (Richardson et al., 2007). Different BBD cyanobacterial isolates were shown to produce the cyanobacterial toxin microcystin-LR (Richardson et al. 2007; Gantar et al., 2009).

It is well known that cyanobacteria produce toxins, termed cyanotoxins (Codd et al., 1999). Cyanotoxins are classified as hepatotoxins (microcystins, nodularin, cylindrospermopsin), cytotoxins (aplysiatoxin, debromoaplysiatoxin, lingbyatoxin, lipopolysaharide endotoxin), and neurotoxins (anatoxin-a and homoanatoxin-a, anatoxina(S), saxitoxins) (Chorus and Bartram, 1999; Dietrich and Hoeger, 2005). Microcystins are the most common group of cyanotoxins. They inhibit protein phosphatases 1 (PP1) and 2A (PP2A) (MacKintosh et al., 1990; Sivonen and Jones, 1999; Humpage et al., 2000). Inhibition of these enzymes is followed by loss of cytoskeletal integrity which leads to subsequent cytolysis or apoptosis, primarily of hepatocytes but also of glomeruli and renal proximal tubule cells (Fischer et al., 2000).

Richardson et al. (2009) recently conducted experiments in which apparently healthy coral fragments were exposed to purified microcystin-LR at concentrations of 1 , 50, and $100 \mu \mathrm{g} \mathrm{L}^{-1}$. Results showed that microcystin affected the structural integrity of the coral tissue and resulted in extrusion of zooxanthellae from the gastrodermis. It was also shown that the lowest concentration of microcystin $\left(1 \mu \mathrm{g} \mathrm{L} \mathrm{L}^{-1}\right)$ promoted bacterial 
growth in the coral tissue. From these results it appears that microcystin is toxic to corals, but on the other hand stimulates growth of at least some species of bacteria. Still further studies on the effect of microcystin on BBD community and corals are needed.

\section{Goal and Hypotheses}

According to the molecular studies discussed above it appears that one species of cyanobacteria, an Oscillatoria, is a consistent member of the BBD consortium. To date limited studies have been carried out to examine its role in BBD because this organism was not available in culture. However, two strains of Oscillatoria (designated 100-1 and 101-1) have been isolated from BBD by members of the Richardson/Gantar laboratory. These strains are not axenic, however the associated bacteria may also be involved with BBD etiology.

The aim of this project was to characterize the BBD Oscillatoria sp. and assess its role in $\mathrm{BBD}$ formation by testing the following hypotheses:

1. Oscillatoria $\mathrm{sp}$. is the primary pathogen of $\mathrm{BBD}$

2. The composition of bacteria associated with Oscillatoria 100-1 differs from that associated with Oscillatoria 101-1

3. Black band disease Oscillatoria spp. are capable of producing cyanotoxins

4. Toxin production of Oscillatoria sp. is affected by environmental factors relevant to coral reefs 


\section{REFERENCES}

Aeby, G.S., and D. L. Santavy (2006) Factors affecting the susceptibility of the coral Montastraea faveolata to black band disease. Marine Ecology Progress Series 318: 103110.

Antonius, A. (1973) New observations on coral destruction in reefs. 10th Meeting Association of Island Marine Laboratories of the Caribbean 10: 3.

Antonius, A. (1981) The 'band' diseases in coral reefs. Proceedings of the Fourth International Coral Reef Symposium. 2: 7-14.

Antonius, A. (1985) Coral diseases in the Indo-Pacific: A first record. PSZNI: Mar Ecol 6: $197-218$.

Antonius, A. (1988) Distribution and dynamics of coral diseases in the eastern Red Sea. Proceedings of the Sixth International Coral Reef Symposium. 3: 145-150.

Aronson, R. B., and W. F. Precht. (1997) Stasis, biological disturbance, and community structure of a Holocene coral reef. Paleobiology 23:326-346.

Aronson, R., and W. Precht. (2001) White-band disease and the changing face of Caribbean coral reefs. Hydrobiologia 460:25-38.

Banin, E., T. Israely, A. Kushmaro, Y. Loya, E. Orr, and E. Rosenberg (2000)

Penetration of the coral-bleaching bacterium Vibrio shiloi into Oculina patagonica. App Environ Microbiol 66: 3031-3036.

Barneah, O., E. Ben-Dov, E. Kramarsky-Winter, and A. Kushmaro (2007) Characterization of black band disease in Red Sea stony corals. Environ Microbiol 9: 1995-2006.

Ben-Haim, Y., M Zicherman-Keren, and E. Rosenberg (2003) Temperature-regulated bleaching and lysis of the coral Pocillopora damicornis by the novel pathogen Vibrio coralliilyticus. Appl Environ Microbiol 69: 4236-4242.

Bindoff, N.L., J. Willebrand, V. Artale, A. Cazenave, and others (2007) Observations: oceanic climate change and sea level. Cambridge University Press, Cambridge.

Borger, J.L. (2005) Scleractinian coral disease in south Florida: incidence, species susceptibility, and mortality. Dis Aquat Organ 67: 249-258.

Borger, J.L., and S. C. C. Steiner (2005) The spatial and temporal dynamics of coral diseases in Dominica, West Indies. Bull Mar Sci 77: 137-154. 
Brown, B.E. (1997) Coral bleaching: causes and consequences. Coral Reefs 16 (suppl), S129-S138.

Brown, B.E., R. P. Dunne, and H. Chansang (1996) Coral bleaching relative to elevated seawater temperature in the Andaman Sea (Indian Ocean) over the last 50 years. Coral Reefs 15: 151-152.

Bruckner, A., and R. Bruckner (1997) The persistence of black band disease in Jamaica: Impact on community structure. Proceedings of the Eight International Coral Reef Symposium 1: 601-606.

Bruckner, A.W., R. J. Bruckner, and E. H. Williams (1997) Spread of a black band disease epizootic through the coral reef system in St. Ann's Bay, Jamaica. Bull Mar Sci 61: 919-928.

Carlton, R.G., and L. L. Richardson (1995) Oxygen and sulfide dynamics in horizontally migrating cyanobacterial mat: black band disease of corals. FEMS Microbiol Ecol 18: $155-162$.

Carpenter, K.E., M. Abrar, G. Aeby, R. B. Aronson and others (2008) One-third of reefbuilding corals face elevated extinction risk feom climate change and local impacts.

Science 321: 560-563.

Chorus I, and J. Bertram (1999) Toxic Cyanobacteria in Water: A Guide to Their Public Health Consequences, Monitoring, and Management, London, UK.

Codd, G.A., S. G. Bell, K. Kaya, C. J. Ward, K. Beattie, and J. S. Metcalf (1999) Cyanobacterial toxins, exposure route and human health. Eur J Phycol 34: 405-415.

Cooney, R.P., O. Pantos, M. D. A. Le Tissier, M. R. Barer, A. G. O’Donnell, and J. C. Bythell (2002) Characterization of the bacterial consortium associated with black band disease in coral using molecular microbiological techniques. Environ Microbiol 4: 401413.

Dietrich, D., and S. Hoeger (2005) Guidance values for microcystins in water and cyanobacterial supplement products (blue-green algal supplements): a reasonable or misguided approach? Toxicology and Applied Pharmacology 203: 273-289.

Dinsdale, E.A. (1994) Coral disease on the Great Barrier Reef. Joint Scientific Conference on Science, Management and Sustainability of Marine Habitats in the 21st Century. Australian Mar. Sci. Assoc., Townsville, Australia, p. 25.

Dinsdale, E.A. (2002) Abundance of black-band disease on corals from one location on the Great Barrier Reef: a comparison with abundance in the Caribbean region. Proceedings of the Ninth International Coral Reef Symposium 2: 1239-1243. 
Ducklow, H.W., and R. Mitchell (1979) Observations on naturally and artificially diseased tropical corals: a scanning electron microscopy study. Microb Ecol 5: 215-223.

Dustan, P. (1999) Coral reefs under stress:sources of mortality in the Florida Keys. Nat Res Forum 23: 147-155.

Dustan, P. (1977) Vitality of reef coral populations off Key Largo, Florida: Recruitment and mortality. Environ Geol 2: 51-58.

Edmunds, P.J. (1991) Extent and effect of black band disease on Caribbean reefs. Coral Reefs 10: 161-165.

Feingold, J.S. (1988) Biologycal studies of a cyanobacterial infection on the Caribbean sea plume Pseudopterogorgia acerosa (Coelenterata: Octocorallia). Proceeding of the Sixth International Coral Reef Symposium, Townsville 3: 157-162.

Fischer, W.J., B.C. Hitzfeld, F. Tencalla, J. E. Eriksson, A. Mikhailov, and D. R. Dietrich (2000) Microcystin-LR toxicodynamics, induced pathology, and immunohistochemical localization in livers of bluegreen algae exposed rainbow trout (Oncorhynchus mykiss). Toxicol Sci 54: 365-373.

Frias-Lopez, J., A. L. Zerkle, G. T. Bonheyo, and B. W. Fouke (2002) Partitioning of bacterial communities between seawater and healthy, black band diseased, and dead coral surfaces. Appl Environ Microbiol 68: 2214-2228.

Frias-Lopez, J., G. T. Bonheyo, Q. S. Jin, and B. W. Fouke (2003) Cyanobacteria associated with coral black band disease in Caribbean and Indo-Pacific Reefs. Appl Environ Microbiol 69: 2409-2413.

Frias-Lopez, J., J. S. Klaus, G. T. Bonheyo, and B. W. Fouke (2004) Bacterial community associated with black band disease in corals. Appl Environ Microbiol 70: $5955-5962$.

Gantar, M., R. Sekar, and L. L. Richardson (2009) Cyanotoxins from Black Band Disease of Corals and from Other Coral Reef Environments. Microb Ecol 58: 856-864.

Gardner, T.A., I. M. Cote, J. A. Gill, A. Grant, and A. G. Watkinson (2003) Long-term region-wide declines in Caribbean corals. Science 301: 958-960.

Garrett, P., and H. Ducklow (1975) Coral diseases in Bermuda. Nature 253: 349-350.

Garzón-Ferreira, J., D. L. Gil-Agudelo, L. M. Barrios, and S. Zea (2001) Stony coral diseases observed in southwestern Caribbean reefs. Hydrobiologia 460: 65-69. 
Geiser, D.M., J. W. Taylor, K. B. Ritchie, and G. W. Smith (1998) Cause of sea fan death in the West Indies. Nature 394: 137-138.

Gladfelter, W.B., E. H. Gladfelter, R.K. Monahan, J.C. Ogden, and R.F. Dill (1977) Environmental studies of Buck Island Reef National Monument, St. Croix US Virgin Islands. Special Report of the National Park Service, US Dept Interior, 173.

Green, E. P., and A. W. Bruckner (2000) The significance of coral disease epizootiology for coral reef conservation. Biol. Conserv 96:347-361.

Harvell, C.D., K. Kim, J. M. Burkholder, R. R. Colwell, P. R. Epstein, D. J. Grimes, E. E. Hofmann, E. K. Lipp, A. D. M. E. Osterhaus, R. M. Overstreet, J. W. Porter, G. W. Smith, and G. R. Vasta. (1999) Emerging marine diseases - climate links and anthropogenic factors. Science 285: 1505-1509.

Harvell, D., E. Jordan-Dahlgren, S. Merkel, L. Raymundo, G. Smith, E. Weil, and B. Willis (2007) Coral disease, environmental drivers, and the balance between coral and microbial associates. Oceanography 20: 172-195.

Hughes, T.P. (1994) Catastrophes, phase shifts, and large-scale degradation of a Caribbean coral reef. Science 265: 1547-1551.

Humpage, A.R., M. Fenech, P. Thomas, and I. R. Falconer (2000) Micronucleus induction and chromosome loss in transformed human white cells indicate clastogenic and aneugenic action of the cyanobacterial toxin, cylindrospermopsin. Mutat Res, Genet Toxicol Environ Mutagen 472: 155-161.

Kaczmarsky, L.T., M. Draud, and E. H. Williams (2005) Is there a relationship between proximity to sewage effluent and the prevalence of coral disease. Caribb J Sci 41: 124137.

Kim, K., and C. D. Harvell (2002) Aspergillosis of sea fan corals: disease dynamics in the Florida Keys. In The Everglades Florida Bay and coral reefs of the Florida Keys: an ecosystem sourcebook, J. W. Porter and K. G. Porter (Eds) CRC Press, New York, 813824.

Kushmaro, A., E. Rosenberg, M. Fine, and Y. Loya (1997) Bleaching of the coral Oculina patagonica by Vibrio AK-1. Marine Ecology Progress Series 147: 159-165.

Kuta, K. (2000) Black band disease of corals: Ecology and physiology of Phormidium corallyticum PhD Dissertation, Florida International University.

Kuta, K.G., and L. L. Richardson (1996) Abundance and distribution of black band disease of corals in the northern Florida Keys. Coral Reefs 15: 219-223. 
Kuta, K.G., and L. L. Richardson (1997) Fate of black band diseased corals in the Florida Keys. Proceedings of the Eighth International Coral Reef Symposium 1: 575-578.

MacKintosh, C., K. A. Beattie, S. Klumpp, P. Cohen, and G. A. Codd (1990) Cyanobacterial microcystin-LR is a potent and specific inhibitor of protein phosphatases 1 and 2A from both mammals and higher plants. FEBS Lett 264.

Miller, I. (1996) Black band disease on the Great Barrier Reef. Coral Reefs 15 : 58.

Myers, J.L., and L. L. Richardson (2009) Adaptation of cyanobacteria to the sulfide-rich microenvironment of black band disease of coral. FEMS Microbiol Ecol 67: 242-251.

Myers, J.L., R. Sekar, and L. L. Richardson (2007) Molecular detection of the cyanobacterial genera Geitlerinema and Leptolyngya in blacka band disease of corals. Appl Environ Microbiol 73: 5173-5182.

Page, C.A., and B. L. Willis. (2006) Distribution, host range and large scale spatial variability in black band disease prevalence on the Great Barrier Reef, Australia. Dis Aquat Organ 69: 41-51.

Peters, E.C. (1993) Diseases of other invertebrate phyla: Porifera, Cnidaria, Ctenophora, Annelida, Echinodermata. In Pathobiology of Marine and Estuarine Organisms, J.A. Couch and J.W. Fournie (Eds). CRC Press, Boca Raton, FL, 393-449.

Porter, J.W., P. Dustan, W. C Jaap, K. L. Patterson, V. Kosmynin, O. W. Meier, M. E. Patterson, and M. Parsons (2001) Patterns of spread of coral disease in the Florida Keys. Hydrobiologia 460: 1-24.

Ragoonath, D.N. (2005) Heterotrophic capabilities and the molecular identification of a cyanobacterium found in black band disease of coral reefs. MS thesis Florida International University, Miami.

Ramos-Flores, T. (1983) Lower marine fungus associated with black line disease in star corals (Montastrea annularis). Biol Bull 165: 129-135.

Richardson, L.L. (1996) Motility patterns of Phormidium corallyticum and Beggiatoa spp. associated with black band disease of corals. Microb Ecol 32: 323-335.

Richardson, L.L. (1998) Coral diseases: what is really known? Trends Ecol Evol 13: 438443.

Richardson, L.L. (2004) Black band disease. In Coral health and disease, E. Rosenberg and Y. Loya (Eds), Springer-Veriag, Berlin, 325-349. 
Richardson, L.L., and J. D. Voss (2005) Changes in a coral population on reefs of the northern Florida Keys following a coral disease epizootic. Mar Ecol Prog Ser 297: 147156.

Richardson, L.L., and K. G. Kuta (2003) Ecological physiology of the black band disease cyanobacterium Phormidium corallyticum. FEMS Microbiol Ecol 43, 287-298.

Richardson, L.L., and R. Aronson (2002) Infectious diseases of reef corals. Proceedings of the Ninth International Coral Reef Symposium 1: 1225-1230.

Richardson, L.L., K.G. Kuta, S. Schnell, and R.G. Carlton (1997) Ecology of the black band disease microbial consortium. Proceedings of the Eighth International Coral Reef Symposium 1: 597-600.

Richardson, L.L., R. Sekar, J. L. Myers, M. Gantar, J. D. Voss, L. Kaczmarsky, E. R. Remily, G. L. Boyer, and P. V. Zimba (2007) The presence of the cyanobacterial toxin microcystin in black band disease of corals. FEMS Microbiol Lett 272: 182-187.

Richardson, L.L., W. Goldberg, K. Kuta, R. Aronson, G. Smith, K. Ritchie, H. Halas, J. Feingold, and S. Miller (1998) Florida's mystery coral killer identified. Nature 392: 557558.

Richardson, L. L., A. W. Miller, E. Broderick, L. Kaczmarsky, M. Gantar, D. Stanić and R. Sekar (2009) Sulfide, microcystin, and the etiology of black band disease. Dis Aquat Organ 87: 79-90.

Rosenberg, E., O. Koren, L. Reshef, R. Efrony, and I. Zilber-Rosenberg (2007) The role of microorganisms in coral health, disease and evolution. Nat Rev Microbiol 5: 355-362.

Rosenberg, E., Y. Ben-Haim, A. Toren, E. Benin, A. Kushmaro, M. Fine, and Y. Loya (1999) Effect of temperature on bacterial bleaching of corals. In Current perspectives in microbial ecology, E. Rosenberg (Eds). ASM Press, Washington DC, 242-253.

Rützler, K., D.L. Santavy, and A. Antonius (1983) The black band disease of Atlantic reef corals: III. Distribution, ecology and development. PSZNI Mat Ecol 4: 29-358.

Sekar, R., D. K. Mills, E. R. Remily, J. D. Voss, and L. L. Richardson (2006) Microbial communities in the surface mucopolysaccharide layer and the black band microbial mat of the black band-diseased Siderastrea siderea. Appl Environ Microbiol 72: 5963-5973.

Shinn, E.A., G. W. Smith, J. M. Prospero, P. Betzer, M. Hayes, V. Garrison, and R. T. Barber (2000) African dust and the demise of Caribbean coral reefs. Geophysical Research Letters 27: 3029-3032. 
Sivonen, K.K., and G. Jones (1999) Cyanobacterial toxins. In Toxic Cyanobacteria in Water, I. Chorus and J. Bartram (Eds). Spon, London, 41- 111.

Smith, G.W., L. D. Ives, I. A. Nagelkerken, and K. B. Ritchie (1996) Caribbean sea-fan mortalities. Nature, 383: 487.

Sokolow, S. (2009) Effects of a changing climate on the dynamics of coral infectious disease: a review of the evidence. Dis Aquat Organ 87: 5-18.

Spalding, M.D., and A. M. Greenfell (1997) New estimates of global and regional coral reef areas. Coral Reefs 16: 225-230.

Sussman, M., D. G. Bourne, and B. L. Willis (2006) A single cyanobacterial ribotyp is associated with both red and black bands on diseased corals from Palau. Dis Aquat Organ 69: 111-118.

Sussman, M., Y. Loya, M. Fine, and E. Rosenberg (2003) The marine fireworm Hermodice carunculata is a winter reservoir and spring-summer vector for the coral bleaching pathogen Vibrio shiloi. Environ Microbiol 5: 250-255.

Sutherland, K.P., J. W. Porter, and C. Torres (2004) Disease and immunity in Caribbean and Indo-Pacific zooxanthellate corals. Mar Ecol Prog Ser 266: 273-302.

Taylor, D.L. (1983) The black band disease of Atlantic reef corals: II. Isolation, cultivation, and growth of Phormidium corallyticum. PSZNI Mar Ecol 4: 321-328.

Viehman S., D. K. Mills., G. W. Meichel, and L. L. Richardson (2006) Culture and identification of Desulfovibrio spp. from black band disease of corals on reefs of Florida Keys and Dominica. Dis Aquat Organ 69: 119-127.

Viehman, T.S., and L. L. Richardson (2002) Motility patterns of Beggiatoa and Phormidium corallyticum in black band disease. Proceedings of the Ninth International Coral Reef Symposium 2: 1251-1255.

Voss, J.D., and L. L. Richardson (2006) Coral diseases near Lee Stocking Island, Bahamas: patterns and potential drivers. Dis Aquat Organ 69: 33-40.

Voss, J.D., D. K. Mills, J. L. Myers, E. R. Remily, and L. L. Richardson (2007) Black band disease microbial community variation on corals in three regions of the wider Caribbean. Microb Ecol 54: 730-739.

Weil, E., G. W. Smith, and D. L. Agudelo (2006) Status and progress in coral reef disease research. Dis Aquat Organ 69: 1-7. 
Weil, E. (2004) Coral reef diseases in the wider Caribbean, p. 35-67. In E. Rosenberg and Y. Loya (ed.), Coral health and disease. Springer-Verlag, Berlin, Germany.

Wheaton, J., W. C. Jaap, J. W. Porter, V. Kosmynin and seven others (2001) EPA/FKNMS Coral Reef Monitoring Project Executive Summary. FKNMS Symposium: an ecosystem report card, Florida Marine Research Institute, St Petersburg, FL.

Wilkinson, C. (2002) Status of coral reefs of the world: 2002. Australian Institute of Marine Science. Townsville.

Wilkinson, C. (2004) Status of coral reefs of the world: 2004. Australian Institute of Marine Science, Townsville

Willis, B.L., C. A. Page, and E. A. Dinsdale (2004) Coral Disease on the Great Barrier Reef. In Coral Health and Disease, E. Rosenberg and Y. Loya (Eds). Springer-Verlag, Berlin, 69-104. 


\title{
CHAPTER II.
}

\section{CHARACTERIZATION OF OSCILLATORIA SP. FROM CARRIBEAN BLACK \\ BAND DISEASE}

\begin{abstract}
Black band disease (BBD) is a pathogenic microbial consortium dominated in terms of biomass by phycoerythrin-rich, gliding, filamentous, non-heterocystous cyanobacteria. The primary pathogen for this coral disease is unknown. However, studies of BBD using molecular methods have shown that one 16S rRNA gene sequence of an Oscillatoria sp. is consistently found in BBD samples worldwide. The aim of this study was to characterize two strains of Oscillatoria sp., designated 101-1 and 100-1, that were isolated into culture from BBD on two BBD-infected Caribbean coral host species, Diploria strigosa and Siderastrea siderea, respectively. Both strains have 16S rRNA gene sequences that match the ubiquitous BBD Oscillatoria sp. Results of infectivity experiments carried out under controlled laboratory conditions showed that both strains are capable of initiating an infection on healthy coral that resembles in situ BBD. Morphological characterization by light microscopy and Scanning Electron Microscopy (SEM) revealed that both strains are unbranched, non-heterocystous, and filamentous and are composed of cylindrical cells. Both Oscillatoria strains have the ability to tolerate $\mathrm{pH}$ values in the range from 4.5 to 10 with optimal growth at $\mathrm{pH} 6$ to 8 . Classical cultivation methods were used to investigate bacteria associated with the non-axenic strains. Five bacterial strains were isolated from the culture medium of Oscillatoria strain 100-1 and six from strain 101-1. Amplicon length heterogeneity polymerase chain reaction (LHPCR) showed higher bacterial diversity associated with strain 100-1 but statistical
\end{abstract}


analysis revealed no significant difference in the number of associated bacteria between the two strains. On the basis of morphological and ultrastractural characteristics, the isolates can be identified either as species of Oscillatoria or Phormidium. However, the 16S rRNA gene sequence data place these strains into the genus Oscillatoria.

Phylogenetic analysis of strain 100-1 positioned this isolate into a cluster with more than 60 uncultured cyanobacteria that were all derived from molecular analysis of BBD samples. On the basis of on these results I suggest that cyanobacteria with this sequence be designated as Caribbean BBD Oscillatoria.

\section{Introduction}

Black band disease (BBD) is found on tropical and subtropical reefs worldwide and is known to contribute to the decline of reef framework corals (Weil, 2004). To date it has been documented on reefs throughout the wider Caribbean (Antonius, 1973; Garrett and Ducklow, 1975; Rützler et al., 1983; Peters 1993; Garzón-Ferreira et al., 2001; Kuta and Richardson, 1996; Voss and Richardson, 2006), the Indo-Pacific (Antonius, 1985; Page and Willis, 2006), the Great Barrier Reef (Dinsdale, 1994; Miller, 1996; Dinsdale, 2002; Willis et al., 2004), and the Red Sea (Antonius, 1988). The band is dominated in terms of biomass by phycoerythrin-rich, gliding, filamentous, non-heterocystous cyanobacteria (Rützler et al., 1983).

Identification of microbial pathogens and their reservoirs in the environment is one of the main focuses of coral disease research today. While seven of the most common coral disease have been characterized to include putative pathogens, Koch's postulates have been fulfilled for only five of them (Rosenberg and Loya 2004). 
Unlike other coral diseases, BBD is caused by a pathogenic microbial consortium (Richardson et al., 1997). Many of the microorganisms that are part of the consortium have been suggested as potential BBD primary pathogens. Early studies proposed the cyanobacterium Phormidium corallyticum as the dominant BBD cyanobacterium and to be the primary pathogen of BBD (Rützler and Santavy, 1983; Taylor, 1983). However, recent molecular studies of the BBD microbial community detected strains of cyanobacteria belonging to the genera Oscillatoria, Geitlerinema, Leptolyngbya and Spirulina (Cooney at al., 2002; Frias-Lopez et al., 2003; Myers et al., 2007), with only one sequence related to Phormidium (Myers et al., 2007). These studies have suggested that different cyanobacterial taxa are also potential BBD primary pathogens. Of these a 16S rRNA gene sequence most closely related to Oscillatoria is consistently found in BBD samples worldwide, implicating it as the prime candidate for a BBD primary pathogen.

In addition to cyanobacteria other pathogens of BBD have been proposed, including sulfate-reducing and sulfide-oxidizing bacteria, and members of the $\alpha$ proteobacteria and Cytophaga (Cooney at al., 2002; Frias-Lopez et al., 2002; Frias-Lopez et al., 2004; Sekar et al., 2006). However, Koch's postulates have not been fulfilled for any of the BBD consortium members, and the primary pathogen is unknown.

Because cyanobacteria dominate the BBD microbial community, and because recently BBD cyanobacteria have been shown to produce a cyanotoxin (Richardson et al. 2007; Gantar et al. 2009) that lyses coral tissue (Richardson et al., 2009), BBD cyanobacteria remain the prime candidate for any BBD primary pathogen. Any investigation into the role of a BBD cyanobacterium as a primary pathogen would of 
necessity include characterization of the pathogen in terms of taxonomic identification. However, cyanobacteria are relatively poorly understood in terms of their phylogenetic relationships. This is particularly the case with representatives of Oscillatoriales. This group includes the genera Oscillatoria, Phormidium, and Lyngbya, which are classically differentiated based on morphological properties of their sheaths (Geitler, 1932). Since these genera are susceptible to the cyanophage LPP-1, they were assigned to the LPP (Lyngbya-Phormidium-Plectonema) group. However, it has been found that susceptibility to the same cyanophage does not represent a valid taxonomic character, and this clade is now believed to be much more heterogeneous than previously thought (Rippka, 1988). Sheath production, phage susceptibility, and morphological features in general have proved to be poor characteristics for cyanobacterial taxonomy and phylogeny. To address this issue Anagnostidis and Komárek (1988) established more stable taxonomic features using a combination of ecological, biochemical, and morphological characters. In particular, emphasis was put on examination of ultrastructural features such as thylakoid arrangement and type of cell division. More recently, use of gene sequence data has been addressed as the preferred method for cyanobacterial taxonomy (Castenholz, 2001); however ecological and physiological characteristics are also utilized to strengthen the genetic approach.

According to molecular studies of BBD, it appears that Oscillatoria is a consistent member of the BBD consortium. To date no studies have been carried out to examine its role in BBD because this organism was not available in culture. However, two strains of Oscillatoria from BBD, designated 100-1 and 101-1, were recently isolated and were the subject of the present study. 
In the present study I describe the two Oscillatoria strains (100-1 and 101-1) for the purpose of taxonomic classification as well as for identification and characterization of features required for initiation of BBD infection.

\section{Materials and Methods}

\section{Experimental organisms}

My BBD samples were collected on a reef site in Frederiksted, St. Croix, U.S. Virgin Islands in June, 2007 while SCUBA diving using sterile, needleless $10 \mathrm{ml}$ syringes. Samples were kept under low-light conditions at ambient temperatures in a cooler during transport to the laboratory. Once in the laboratory the samples were aseptically transferred to test tubes that contained ASN III medium (Rippka et al., 1979). Cyanobacteria were isolated from the BBD samples using the gliding method described by Castenholz (1988). Single cyanobacterial filaments that had glided out from the initial point of inoculation were cut from the agar surface using a sterile watchmaker's forceps and transferred into liquid ASN III media. Laboratory cultures were maintained at $27^{\circ} \mathrm{C}$ and $30 \mu \mathrm{Em}^{-2} \mathrm{~s}^{-1}$ under $24 \mathrm{~h}$ of constant cool-white light (Philips, F34T12/CW/RS/EW). Cultures were transferred every three weeks to fresh culture media. Both strains were non-axenic (contained associated bacteria).

\section{Light microscopy}

Two week old cultures of Oscillatoria strains 100-1 and 101-1, grown as described above, were observed and photographed using a digital camera attached to a Leica DC 500 microscope. 


\section{Scanning electron microscopy (SEM)}

Filaments of Oscillatoria sp. strains (100-1 and 101-1) were fixed in 2.5\% glutaraldehyde and maintained at $4^{\circ} \mathrm{C}$ for 24 hours. After fixation, filaments were dehydrated through a series of graded ethanol to a final concentration of $100 \%$. Samples were dried in a critical point dryer (Tousimis, Rockville, MD), after which they were affixed to an aluminum stub using carbon adhesive tape and coated with palladium/gold using a sputter coater (SPI-Module). Samples were viewed using a Joel JSM-5900 LV SEM at Florida International University.

\section{Transmission electron microscopy (TEM)}

Both Oscillatoria strains were prepared by fixing filaments in $2.5 \%$ glutaraldehyde followed by postfixation in $1 \% \mathrm{OsO}_{4}$, dehydration in a graded series of alcohol, and embedding in Spur's resin. Thin gold sections from the block were cut using a Sorval MT-2 ultramicrotome fitted with a diamond knife. Sections were placed on copper grids and stained with lead citrate (Reynolds, 1963). They were viewed using a Joel 1200X TEM at University of Miami.

\section{Pigment analysis}

Pigment (phycobilins) extracts were prepared by extracting $100 \mathrm{mg}$ of dry biomass of each strain in $10 \mathrm{ml}$ of $0.1 \mathrm{~N}$ phosphate buffer $(\mathrm{pH}=7)$. After centrifugation, the supernatant was filtered through a membrane filter $(0.45 \mu \mathrm{m}$ pore size $)$. The visible spectrum was scanned (absorbance) using a microplate reader (Synergy 2, BioTek Instruments, Inc.). 


\section{Growth at different $\mathrm{pH}$ values}

Both Oscillatoria strains were tested for their tolerance to different $\mathrm{pH}$ values. The ASNIII medium was buffered with addition of MES buffer at a concentration of $0.5 \mathrm{~g} \mathrm{l}^{-1}$ and adjusted by adding base $(\mathrm{NaOH})$ or acid (HCL) to produce $\mathrm{pH}$ levels of 4.5 , 5.5, 6.0, 7.0, 8.0, 9.0, and 10.0. Erlenmeyer flasks containing $30 \mathrm{ml}$ of medium were inoculated with the cyanobacterial cultures, using filament suspensions produced by homogenizing cultures with a hand-held mixer. The cultures were incubated at $27^{\circ} \mathrm{C}$. Biomass yield was determined as chlorophyll $a$ concentration by filtering the whole culture volume $(30 \mathrm{ml})$ through Whatman GF/B filters and extracting the biomass with $100 \%$ methanol at $4^{\circ} \mathrm{C}$ for $24 \mathrm{~h}$. Chlorophyll concentration was determined spectrophotometrically according to Dere et al. (1998).

Isolation of bacteria associated with cultures of Oscillatoria strains 100-1 and 101-1 Individual bacterial strains were isolated from both Oscillatoria cultures using classical cultivation methods. Marine agar plates were inoculated with $100 \mu$ of culture media and spread plated. Colonies were selected based on color and morphology, picked, and restreaked onto fresh marine agar plates to purity.

\section{DNA extraction and $16 S \mathrm{rRN} A$ gene amplification}

Genomic DNA was extracted from both Oscillatoria strains using a FastDNA SPIN kit for soil (Q-Biogene), following a slightly modified protocol as previously described (Mills et al., 2003). Extracted DNA was verified by electrophoresis in a 1\%

agarose gel, quantified with a Bio-Rad VersaFluor fluorometer, and subsequently diluted to $10 \mathrm{ng} / \mu \mathrm{l}$ solution. 
Cyanobacterial 16S rRNA genes were amplified using cyanobacteria specific primers CYA359F (5'-GGG GAA TYT TCC GCA ATG GG-3') and CYA781R(b) (5'GAC TAC AGG GGT ATC TAA TCC CTT T-3') (Nübel et al., 1997). Final PCR concentrations were as follows: 1 X PCR buffer, $2.5 \mathrm{mM} \mathrm{MgCl} 2,0.25 \mathrm{mM}$ of each deoxynucleoside triphosphate, $0.5 \mu \mathrm{M}$ of each primer, $0.5 \mathrm{U}$ AmpliTaq Gold DNA polymerase (Applied Biosystems), 0.1\% bovine serum albumin, $10 \mathrm{ng}$ of genomic DNA, and nuclease-free water added to a final volume of $20 \mu \mathrm{l}$. The PCR reactions were carried out in a PTC-200 model Peltier thermal cycler (MJ Research, Waltham, MA), with an initial denaturing step at $95^{\circ} \mathrm{C}$ for $5 \mathrm{~min}$, followed by 25 cycles of $95^{\circ} \mathrm{C}$ for $1 \mathrm{~min}, 55^{\circ} \mathrm{C}$ for $1 \mathrm{~min}$, and $72{ }^{\circ} \mathrm{C}$ for $1 \mathrm{~min}$, with a final extension step at $72{ }^{\circ} \mathrm{C}$ for $10 \mathrm{~min}$. The PCR products were run on an agarose gel, along with a negative control (DNA grade water), for verification prior to purification with a QIAquick PCR purification kit (QIAGEN Inc., Valencia, CA). Sequencing was performed at the DNA Core Facility at Florida International University, Miami, FL, on an ABI Prism 3100 genetic analyzer (Applied Biosystems). To identify their closest relatives in GenBank, sequences were analyzed using BLAST (http://www.ncbi.nlm.nih.gov/BLAST/).

For bacterial cultures genomic DNA was extracted using the Bactozol ${ }^{\mathrm{TM}} \mathrm{Kit}$ (Molecular Research Center Inc.). Bacterial 16S rRNA genes were amplified using the universal bacterial primers 27F (5'-AGA GTT TGA TCM TGG GTC AG-3') and 1492R (5'-TAC GGY TAC CTT GTT ACG ACT T-3') (Muyzer et al., 1995). Final PCR concentrations and reactions were as described above.

Sequencing was performed at the Florida International University (FIU) DNA Core Facility on an ABI Prism 3100 genetic analyzer (Applied Biosystems). BLAST 
(http://www.ncbi.nlm.nih.gov/BLAST/) was used to analyze sequences in order to identify the closest relative in GenBank.

\section{Clumping behavior}

Clumping behavior was investigated for both Oscillatoria strains and, for comparison, seven other cyanobacterial strains isolated from BBD. Experiments were performed in the light and the dark. The two Oscillatoria strains (100-1 and 101-1), five strains of Geitlerinema sp. (HS-217, W-1,1991, P2b and HS 223) and two strains of Leptolyngbya sp. (102d-1 and 102e-1) were first homogenized by a hand-held homogenizer for $10 \mathrm{sec}$. Homogenized biomass $(500 \mu \mathrm{l})$ of each strain was dispensed into two 48-well plates (in triplicate for each plate). One set of plates was exposed to light (30 $\mu \mathrm{E} \mathrm{m}-1 \mathrm{~s}-1)$ and the other was kept in the dark. Dark conditions were obtained by wrapping the plate in aluminum foil. The average biomass (dry weight) used per well for the experiment was $8.8 \mathrm{mg}$. Extent of filament clumping was recorded by taking digital pictures after 5, 10, 15 and $30 \mathrm{~min}$. The rate of clumping was determined by measuring the diameter of clumped biomass in each well using image analysis software (Image $\mathrm{J}$ software $1.40 \mathrm{~g}$ ) and was expressed as percentage of area decrease relative to the freshly dispersed cultures.

\section{Amplicon-length heterogeneity (LH) PCR}

Genomic DNA extracted from the non-axenic cultures of Oscillatoria strains 1011 and 100-1 was used for amplification of the hypervariable V1 and V2 domains of the 16S rRNA gene using the fluorescently labeled forward primer 27F-6-FAM (5'-6-FAMAGA GTT TGA TCM TGG CTC AG-3') and non-fluorescently labeled reverse primer 355R (5'-GGT GCC TCC CGT AGG AGT-3') (Integrated DNA Technologies) (Suzuki 
et al., 1998). The composition, final concentrations of reagents, and PCR reactions were performed as above. The PCR products were verified on an agarose gel along with a 100 bp DNA ladder (Promega) and 5x loading dye (Qiagen). The PCR products were analyzed at FIU's International Forensic Research Institute's DNA Profiling Facility. Separation of PCR products was performed on an ABI 310 DNA genetic analyzer with capillary electrophoresis. Resulting electropherograms were analyzed using ABI Prism Genemapper version 4.0 software. Analysis was limited to amplicons that ranged between 300 and 400 base pair (bp) in length. Bins were set to $1 \mathrm{bp}$ in width, with the minimum peak intensity threshold set to 50 relative fluorescent units.

\section{Phylogenetic analysis}

Forward and complementary sequences were aligned using the CLUSTAL W Multiple Sequence Alignment Program (Thompson et al., 1994), and compared to fifty cyanobacterial sequences within GenBank (http://www.ncbi.nlm.nih.gov) that were most closely related based on the 16S rRNA gene. Some of these sequences were identified in GenBank as Oscillatoria, including uncultured Oscillatoriales clones derived from BBD. These sequences exhibited $\geq 97 \%$ sequence homology to the two laboratory strains. Sequences were aligned using MacClade (Maddison and Maddison, 1992). Phylogenetic analysis, employing Maximum Parsimony and Maximum Likelihood, was performed using PAUP ver. 4.02b (Swofford, 1998).

\section{Statistical analysis}

Statistical analysis was performed using the software SPSS version 11.0. The significance between the number of bacteria associated with the two strains (Oscillatoria 100-1 and 101-1) was tested by paired sample $\mathrm{T}$ test. The significance between different 
treatments (growth at different $\mathrm{pH}$ values) was tested by one way ANOVA and Bonferroni multiple-comparisons test.

\section{Results}

\section{Experimental organisms}

The BLAST analysis of both Oscillatoria sequences revealed that they are most closely related (97 -99\% sequence homology) to numerous (over 60) cyanobacteria deposited as "uncultured cyanobacteria" in GenBank and whose source was molecular analysis of BBD samples. The sequence also matched (97\%), the cyanobacterial strain BgP10_4S $\mathrm{S}^{\mathrm{T}}$ isolated from BBD in the Red Sea (Eilat), which has been designated as Pseudoscillatoria coralii (FJ210722.2). The top three sequences in GenBank that matched the strains 100-1 and 101-1 and accompanying references are listed in Table 1. The additional strains (over 60; see legend in Table 1) were deposited in GenBank as "uncultured" in association with several molecular studies of BBD (Cooney et al., 2002; Frias-Lopez et al., 2002; Sekar et al., 2009).

Based on light microscopy, both strains appeared similar. They were motile (gliding motility), non-heterocystous, unbranched trichomes, $3.5 \mu \mathrm{m}$ wide, with an average cell length of $3.5 \mu \mathrm{m}$ (Figure 1). Both tapering and rounded end cells could be distinguished in both strains (Figure 2). However, SEM analysis revealed a difference in the appearance of the trichome surface between the two strains in that the cell surface of strain 100-1 appeared rough while that of strain 101-1 appeared smooth (Figure 1). A TEM of trichome cross-sections showed that both strains had a radial thylakoid arrangement, with thylakoids occupying most of the cell volume. Individual trichomes were surrounded by a sheath, which differed in appearance between the two strains 
(Figure 3). In strain 100-1 the sheath appeared to be thick and loose, while in strain 101-1 it was thinner and more firmly attached to the cell surface.

Cultures of both strains appeared brownish-red in color. Spectral analysis (Figure 4) of cell extracts (aqueous) of both strains revealed the presence of two peaks, one at $565 \mathrm{~nm}$ and the other at $548 \mathrm{~nm}$, which is characteristic of the light-harvesting pigment phycoerythrin (Rowan, 1989). In addition, there was a shoulder at $620 \mathrm{~nm}$ in both strains indicative of phycocyanin. The ratio of absorbance $(565: 620 \mathrm{~nm})$ was the same for both strains (1.6), indicating equal amounts of both pigments.

\section{Growth at different $\mathrm{pH}$}

Both strains were capable of growth at a wide range of $\mathrm{pH}$ values (between 4.5 and 10). However, strain 100-1 appeared to be more $\mathrm{pH}$ tolerant than strain 101-1. For the strain 100-1 the biomass yield was not significantly different at $\mathrm{pH}$ values from 5.5 to 8.0. Significant decreases in biomass yield were recorded at $\mathrm{pH}$ values 4.5, 9.0 and 10.0. On the other hand, strain 101-1 had the highest biomass yield at $\mathrm{pH}$ 7.0, which was significantly higher than the yield at $\mathrm{pH} 8.0$ (Figure 5).

Growth characteristics of the two Oscillatoria strains were dependent on the $\mathrm{pH}$ of the growth medium. Namely, in the case of the strain 100-1, filaments tended to form tightly packed clumps floating on the surface of the medium at $\mathrm{pH}$ values $4.5,5.5,6.0$, and 10.0, which was also observed in strain 101-1 at $\mathrm{pH} 4.5$ and 5.5. At other $\mathrm{pH}$ values the filaments attached to and coated the walls of the Erlenmeyer flasks (Figure 6).

\section{LH-PCR profiling of bacteria associated with cultured Oscillatoria strains}

Using classical isolation methods, five bacterial strains were isolated from the culture medium of Oscillatoria 100-1 and six from Oscillatoria 101-1 (Tables 2 and 3). 
Gram staining and light microscopy were performed on each bacterial strain and revealed that the isolated bacteria were predominantly (10 out of 11$)$ gram negative rods.

The LH-PCR analysis resulted in a total of 11 amplicons ranging from 313 to 349 bp present in the sample of Oscillatoria strain 100-1, and only three amplicons ranging from 304 to $341 \mathrm{bp}$ in the sample of Oscillatoria strain 101-1 (Figure 7). The dominant amplicon in both samples was $315 \mathrm{bp}$ long, which corresponds to the amplicon length of cyanobacteria (Sekar et al., 2006). Two of the amplicons (304 and $341 \mathrm{bp)} \mathrm{were} \mathrm{unique} \mathrm{to}$ Oscillatoria strain 101-1, and ten amplicons $(313,319,325,328,337,343,345,346,347$, $349 \mathrm{bp)}$ were unique to Oscillatoria strain 100-1. Strain 100-1 also showed higher bacterial diversity than strain 101-1. However, statistical analysis showed no significant difference in number of bacteria between the samples.

\section{Clumping behavior}

The conspicuous clumping behavior of the Oscillatoria strains when grown in liquid culture was compared to seven other BBD cyanobacterial isolates. In the light pronounced clumping and contraction of cyanobacterial filaments was observed for both Oscillatoria strains and for two strains of BBD Geitlerinema (HS-217 and W-1) (Figure 8). The most pronounced clumping was observed for Oscillatoria strains 100-1 and 101-1 in which the original dispersed culture contracted to an area that was reduced by $85.2 \%$ and 73.2\%, respectively. The Geitlerinema strains HS-217 and W-1 exhibited less pronounced clumping, with a decrease in the original dispersed area of $53.8 \%$ and $58.9 \%$, respectively. The rate of clumping over time for the four strains that showed the ability to form clumps is presented in Figure 9. 
When the clumping experiment was repeated under dark conditions it was determined that only the Oscillatoria strains had the ability to form clumps (Figure 10). Strain $100-1$ exhibited a decrease in area of $77.8 \%$ and strain $101-1$ of $68.7 \%$.

\section{Phylogenetic analysis}

Phylogenetic analysis (Figure 11) showed that the sequence of Oscillatoria 100-1 was closely related to cyanobacterial sequences that were derived from molecular analysis of BBD and which were deposited as 'uncultured cyanobacteria' in GenBank. Together, all of these sequences were most closely related to Oscillatoria sp. The same clade also contained the newly described BBD cyanobacterium Pseudoscillatoria coralii (Rasoulouniriana et al., 2009).

\section{Discussion}

The first exhaustive morphological study of a cyanobacterium found in BBD was published by Rützler and Santavy (1983) and included light microscopy, SEM and TEM. The authors of this paper identified the BBD cyanobacterium as Phormidium corallyticum. However, their studies were conducted using field samples without having the organism in culture. At that time, molecular methods of taxonomic identification were not available. More recently BBD cyanobacteria have been classified, based on 16S rRNA gene sequence data, as belonging to the cyanobacterial genera Geitlerinema, Leptolyngbya, Spirulina and Phormidium in addition to Oscillatoria (Cooney at al., 2002; Frias-Lopez et al., 2003; Ragoonath, 2005; Myers et al., 2007).

The strains investigated in this study were motile (gliding motility), nonheterocystous, and had unbranched trichomes. Morphologically, the trichomes of both Oscillatoria strains resembled those described by Rützler and Santavy (1983) and by 
Rasoulouniriana et al. (2009). Whereas the isolates examined in this study had trichomes that consisted of an average of more than 30 cells with a cell size of $3.5 \times 3.5 \mu \mathrm{m}$, Rützler and Santavy (1983) measured cells (similar trichome length) that were $4.2 \times 4.0 \mu \mathrm{m}$. In contrast, Pseudoscillatoria coralii (Rasoulouniriana et al., 2009) had short filaments with cell widths of 5-6 $\mu \mathrm{m}$. Trichomes of all three cyanobacteria, i.e. Oscillatoria, Pseudoscillatoria coralii and Phormidium corallyticum, had both tapered and rounded end cells.

Cultures of Oscillatoria strains 100-1 and 101-1 were brownish-red in appearance as a result of the high content of phycoerythrin, identified by the characteristic peak at $565 \mathrm{~nm}$.

The 16S rRNA gene sequence data indicated that the Oscillatoria strains were closely related to each other (97\%), and to numerous clones derived from BBD and deposited in GenBank as "uncultured cyanobacterium". The sequence was also 97\% homologous to a newly reported BBD cyanobacterial strain BgP10_4S ${ }^{\mathrm{T}}$ (Pseudoscillatoria coralii) isolated from the Red Sea (Rasoulouniriana et al., 2009). This isolate is discussed in detail below in comparison to the Oscillatoria strains that were the focus of the present study.

Thylakoid arrangement is one of the classical taxonomic characteristics used for classification of cyanobacteria. The TEM of the Oscillatoria strains revealed a radial thylakoid arrangement characteristic of members of genus Phormidium (Anagnostidis and Komarek, 1988) and observed for Phormidium corallyticum described by Rützler and Santavy (1983). Ultrastructural study of the Oscillatoria strains in the current study revealed the presence of a sheath in both strains. Sheaths are a characteristic present in 
both Phormidiaceae and Oscillatoriaceae. The consistency and appearance of the sheaths were different in the two strains. In strain 100-1 the polysaccharide sheath was more dispersed with a tendency to slough off which contributed to the rough appearance of the trichome surface when viewed using SEM (Figure 1). Strain 101-1 had a thinner sheath than strain 100-1 and similar to that shown in Phormidium corallyticum (Rützler and Santavy, 1983).

Both Oscillatoria strains showed the ability to grow at a wide range of $\mathrm{pH}$ values, from 4.5 to 10.0, with optimal growth between 6.0 and 8.0 in the case of strain 100-1 and at 7.0 to 8.0 in the case of strain 101-1. It is known that the $\mathrm{pH}$ of the coral surface mucopolysaccharide layer (SML) is 5.5 (Phillips, 1963). Therefore, the surface of the host coral can be a favorable environment for growth of these cyanobacteria. Both Oscillatoria strains not only thrived at low $\mathrm{pH}$ values, but they also exhibited enhanced clumping behavior at low $\mathrm{pH}$. When grown in acidic media both strains tended to form clumps with tightly packed filaments (Figure 6). There is a general belief that clumping of cyanobacteria is a mechanism used to evade exposure to excessive light intensity by self-shading (Castenholz, 1982). However, in the case of Oscillatoria 100-1 and 101-1 there may be an additional ecological benefit to this behavior since it was observed under both light and dark conditions. When clumping ability was compared with the other BBD cyanobacteria isolates (members of the genera Leptolyngbya and Geitlerinema) not only did the Oscillatoria strains clump more tightly, they were able to clump in the dark. The relatively much greater ability of Oscillatoria to form clumps could be associated with the observed capability of these filaments to attach to surfaces, including the coral SML. 
Recently a group in Israel (Rasoulouniriana et al., 2009) published a paper characterizing a cyanobacterium isolated from BBD in the Red Sea. This group proposed to classify the isolate as a new genus and species, which they named Pseudoscillatoria coralii. In the present work the Caribbean BBD Oscillatoria strains 100-1 and 101-1 were characterized for both taxonomic identification and for comparison with BBD cyanobacteria described by others (see Table 4). The Caribbean Oscillatoria strains had smaller cell dimensions in comparison to Pseudoscillatoria coralii (Rasoulouniriana et al., 2009). Additionally cultures of both Oscillatoria strains were brownish-red in color, in contrast to the study of Rasoulouniriana et al. (2009) in which the culture of Pseudoscillatoria coralii was dark green in appearance because the dominant pigment is phycocyanin instead of phycorethrin. The absence of a mucous layer in Pseudoscillatoria coralii (Rasoulouniriana et al., 2009) is another characteristic that distinguishes this isolate form Oscillatoria strains 100-1 and 101-1.

It is well known that most cyanobacterial cultures are not axenic and that it is extremely hard, almost impossible, to obtain bacteria-free cultures. Bacteria may be embedded in the mucilaginous sheath, which they can use as a carbon source. An axenic culture would be of a great value because it would enable physiological studies of the cyanobacterium without any potential interaction with associated microorganisms. At one point during my research I did obtain an axenic culture of strain 101-1, and successfully maintained it for about six months, after which it lost viability. Even though axenic cyanobacterial cultures do exist, there are some cyanobacteria that apparently cannot survive without the presence of associated bacteria. 
Interrelationships between cyanobacteria and bacteria are complex and multidirectional. It is known that co-cultivation of cyanobacteria with various heterotrophic bacteria can lead to either stimulation, inhibition, or even lysis of cyanobacteria (Gantar, 1985). When a freshwater microalga Chlorella sp. was cocultivated with Azospirillum brasilense induction of significant changes in the microalgal-population size, cell size, cell cytology, pigment composition, lipid content and fatty acids produced was observed (De-Bashan et al., 2002). The potential effect of bacteria associated with BBD Oscillatoria is not known. Apparently, they play a critical role in the survival of this cyanobacterium. Additionally one may question their potential role in formation of the complex BBD community, toxin production, and mat forming behavior. Using classical cultivation methods five strains of bacteria were isolated from the culture medium of Oscillatoria strain 100-1 and six from strain 101-1. Of the eleven strains isolated only two isolates were detected in clone libraries produced from BBD. These were an alphaproteobacterium (Cooney et al., 2002; Sekar et al., 2006; Sekar et al. 2008) and a Vibrio sp. (Frias-Lopez et al., 2002). The LH-PCR analysis, which would detect all bacteria present, showed a higher bacterial diversity for strain 100-1 as represented by a higher number of amplicons (11) in comparison to strain 101-1 (3). However, t-test showed no significant difference in the number of amplicons between the samples.

The cyanobacteria investigated in this work, Oscillatoria strains 100-1 and 101-1, were the first isolates from BBD that have shown to be able to initiate infection of apparently healthy coral fragments under controlled laboratory conditions (Chapter IV). In addition, the $16 \mathrm{~S}$ rRNA gene sequences of these strains correspond to those of 
Oscillatoria found in BBD samples world-wide (Frias-Lopez et al., 2002, 2003; Sussman et al., 2006; Barneah et al., 2007; Myers et al., 2007; Rasoulouniriana et al., 2009, Sekar et al., 2009). There is currently no accepted definition of a 'species' for cyanobacteria and cyanobacterial taxonomy is currently being revised (Castenholz, 2001). It is accepted that any cyanobacterial classification to the species level must be based on a combination of diagnostic phenotypic features and genomic properties (Oren, 2004). In the current study I can propose that the cyanobacterial 'species' which includes strains 100-1 and 101-1 is a crucial component of BBD, and may even be the primary BBD pathogen. Taxonomic identification is therefore of primary significance.

On the basis of morphological and ultrastructural characteristics, and by using the classification system of Anagnostidis and Komarek (1988), the isolates can be identified either as species of Oscillatoria or Phormidium. However based on the current, widely accepted molecular approach, these isolates are clearly members of the Oscillatoria. I propose that these strains, as well as the 'uncultured cyanobacteria' deposited in GenBank and isolated from the Caribbean, be referred to as Caribbean BBD Oscillatoria. 


\section{REFERENCES}

Anagnostidis, K., and J. Komarek (1988) Modern approach to the classification system of the cyanophytes. 3. Oscillatoriales. Arch Hydrobiol Algol Stud 50-53: 327-472.

Antonius, A. (1973) New observations on coral destruction in reefs. 10th Meeting Association of Island Marine Laboratories of the Caribbean 10: 3.

Antonius, A. (1985) Coral diseases in the Indo-Pacific: A first record. PSZNI: Mar Ecol 6: $197-218$.

Antonius, A. (1988) Distribution and dynamics of coral diseases in the eastern Red Sea. Proceedings of the Sixth International Coral Reef Symposium 3: 145-150.

Barneah, O., E. Ben-Dov, E. Kramarsky-Winter, and A. Kushmaro (2007) Characterization of black band disease in Red Sea stony corals. Environ Microbiol 9: 1995-2006.

Castenholz, R.W. (1988) Culturing methods for cyanobacteria. Methods Enzymol 167: 68-93.

Castenholz, R. W. (1982) Motility and taxes. In Biology of cyanobacteria, N. G. Carr and B. A. Whitton (Eds). Blackwell Scientific Publications, Ltd., Oxford, 414-439.

Castenholz, R. W. (2001) Phylum BX. Cyanobacteria. In Bergey's Manual of Systematic Bacteriology. Volume 1: The Archaea and the Deeply Branching and Phototrophic Bacteria, G. M. Garrity, D. R. Boone, and R. W. Castenholz (Eds). Second Edition. Springer-Verlag, New York, 473-599

Cooney, R.P., O. Pantos, M. D. A. Le Tissier, M. R. Barer, A. G. O’Donnell, and J. C. Bythell (2002) Characterization of the bacterial consortium associated with black band disease in coral using molecular microbiological techniques. In Environ Microbiol pp.401-413.

De-Bashan, L. E., Y. Bashan, M. Moreno, V. K. Lebsky, and J. J. Bustillos (2002) Increased pigment and lipid content, lipid variety, and cell and population size of the microalgae Chlorella spp. when co-immobilized in alginate beads with the microalgaegrowth-promoting bacterium Azospirillum brasilense. Can. J. Microbiol. 48: 514-521.

Dere, S., T. Gunes, and R. Sivaci (1998) Spectrophotometric determination of chlorophyll-a, $\mathrm{b}$ and total carotenoid contents of some algae species using different solvents. Tr J Botany 22: 13-17. 
Dinsdale, E.A. (1994) Coral disease on the Great Barrier Reef. Joint Scientific Conference on Science, Management and Sustainability of Marine Habitats in the 21st Century. Australian Mar. Sci. Assoc., Townsville, Australia, 25.

Dinsdale, E.A. (2002) Abundance of black-band disease on corals from one location on the Great Barrier Reef: a comparison with abundance in the Caribbean region. Proceedings of the Ninth International Coral Reef Symposium 2: 1239-1243.

Frias-Lopez, J., G. T. Bonheyo, Q. S. Jin, and B. W. Fouke (2003) Cyanobacteria associated with coral black band disease in Caribbean and Indo-Pacific Reefs. Appl Environ Microbiol 69: 2409-2413.

Frias-Lopez, J., A. L. Zerkle, G. T. Bonheyo, and B. W. Fouke (2002) Partitioning of bacterial communities between seawater and healthy, black band diseased, and dead coral surfaces. Appl Environ Microbiol 68: 2214-2228.

Frias-Lopez, J., J. S. Klaus, G. T. Bonheyo, and B. W. Fouke (2004) Bacterial community associated with black band disease in corals. Appl Environ Microbiol 70: 5955-5962.

Gantar, M.(1985): The effect of heterotrophic bacteria on the growth of Nostoc sp. (Cyanobacterium). Arch. Hydrobiol. 4: 445-452.

Gantar, M., R. Sekar, and L. L. Richardson (2009) Cyanotoxins from Black Band Disease of Corals and from Other Coral Reef Environments. Microb Ecol 58: 856-864.

Garrett, P., and H. Ducklow (1975) Coral diseases in Bermuda. Nature 253: 349-350.

Garzón-Ferreira, J., D. L. Gil-Agudelo, L. M. Barrios, and S. Zea (2001) Stony coral diseases observed in southwestern Caribbean reefs. Hydrobiologia 460: 65-69.

Geitler, L. (1932) Cyanophyceae. In Kryptogamen- flora von Deutschland, Österreich und der Schweiz Akademishe Verlagsgesellschaft, L. Rabenhorst (Eds). Leipzig 14: 1196.

Kuta, K.G., and L. L. Richardson (1996) Abundance and distribution of black band disease of corals in the northern Florida keys. Coral Reefs 15: 219-223.

Maddison, W.P., and D. R. Maddison (1992) MacClade, version 3.0 Sinauer Associates, Sunderland, MA

Miller, I. (1996) Black band disease on the Great Barrier Reef. Coral Reefs 15: 58.

Mills, D.K., K. Fitzgerald, C. D. Litchfield, and P. M. Gillevet (2003) A comparison of DNA profiling techniques for monitoring nutrient impact on microbial community 
composition during bioremediation of petroleum- contaminated soils. J Microbiol Methods 54: 57-74.

Muyzer, G., A. Teske, C. O. Wirsen, and H. W. Jannasch (1995) Phylogenetic relationship of Thiomicrospira species and their identification in deep-sea hydrothermal vent samples by denaturing gradient gel electrophoresis of $16 \mathrm{~S}$ rDNA fragments. Arch Microbiol 164: 165-172.

Myers, J.L., R. Sekar, and L. L. Richardson (2007) Molecular detection of the cyanobacterial genera Geitlerinema and Leptolyngya in blacka band disease of corals. Appl Environ Microbiol 73: 5173-5182.

Nübel, U., F., Garcia-Pichel, and G. Muyzer (1997) PCR primers to amplify 16S rRNA genes from cyanobacteria. Appl Environ Microbiol 63: 3327-3332.

Oren, A. (2004) Prokaryote diversity and taxonomy: current status and future challenges.Phil Trans $R$ Soc Lond B 359: 623-638.

Page, C.A., and B. L. Willis. (2006) Distribution, host range and large scale spatial variability in black band disease prevalence on the Great Barrier Reef, Australia. Dis Aquat Organ 69: 41-51.

Peters, E.C. (1993) Diseases of other invertebrate phyla: Porifera, Cnidaria, Ctenophora, Annelida, Echinodermata. In Pathobiology of Marine and Estuarine Organisms, J.A. Couch and J.W. Fournie (Eds). CRC Press, Boca Raton, FL, 393-449.

Phillips, J. H. (1963) Immune mechanisms in the phylum Coelenterata. In The Lower Metazoa: Comparative Biology and Phylogeny. E. C. Dougherty, Z. N. Brow, E. D. Hanson, and W. D. Hartman (Eds.). University of California Press, Berkeley, 425-431.

Ragoonath, D. N. 2005. Heterotrophic capabilities and the molecular identification of a cyanobacterium found in black band disease of coral reefs. M.S. thesis. Florida International University, Miami.

Rasoulouniriana, D., N. Siboni, E. Ben-Dov, E. Kramarsky-Winter, Y. Loya, and A. Kushmaro (2009) Pseudoscillatoria coralii gen. nov., sp. nov., a cyanobacterium associated with coral black band disease (BBD). Dis Aquat Org 87: 91-96.

Richardson L. L., A. W. Miller, E. Broderick, L. Kaczmarsky, M. Gantar, D. Stanić, and R. Sekar (2009) Sulfide, microcystin, and the etiology of black band disease. Dis Aq Org 87: 79-90.

Richardson, L. L., R. Sekar, J. L. Myers, M. Gantar, J. D. Voss, L. Kaczmarsky, et al. (2007) The presence of the cyanobacterial toxin microcystin in black band disease of corals. FEMS Microbiol Lett 272: 182-187. 
Richardson, L.L., and K. G. Kuta (2003) Ecological physiology of the black band disease cyanobacterium Phormidium corallyticum. FEMS Microbiol Ecol 43: 287-298.

Richardson, L. L., K. G. Kuta, S. Schnell, and R. G. Carlton (1997) Ecology of the black band disease microbial consortium. Proceedings of the Eighth International Coral Reef Symposium 1: 597-600.

Rippka, R., J. Dervelles, J. B. Waterbury, M. Herdman, and R. Y. Stanier (1979) Generic assignments, strain histories and properties of pure cultures of cyanobacteria. $J$ Gen Microbiol 111: 1-61.

Rippka, R .J. (1988) Recognition and identification of cyanobacteria. Methods Enzymol 167: 34-72.

Rosenberg, E. and Y. Loya. (2004) Coral health and disease. Springer-Verlag, Berlin, Germany.

Rowan, K. S. (1989) Photosynthetic pigments of algae. Cambridge University Press, Cambridge, USA

Rützler, K., and D. Santavy (1983) The black band disease of Atlantic reef corals. I. Description of a cyanophyte pathogen. Mar Ecol 4: 301-319.

Rützler, K., D.L. Santavy, and A. Antonius (1983) The black band disease of Atlantic reef corals: III. Distribution, ecology and development. PSZNI Mat Ecol 4: 29-358.

Sekar, R., D. K. Mills, E. R. Remily, J. D. Voss, and L. L. Richardson (2006) Microbial communities in the surface mucopolysaccharide layer and the black band microbial mat of the black band-diseased Siderastrea siderea. Appl Environ Microbiol 72: 5963-5973.

Sekar, R., L. T. Kaczmarsky, and L. L. Richardson (2008) Microbial community composition of black band disease on the coral host Siderastrea siderea from three regions of the wider Caribbean. Mar Ecol Prog Ser 362: 85-98.

Sekar, R., L. Kaczmarsky, L., and L. L. Richardson (2009) Effect of freezing on PCR amplification of the 16S rRNA gene from microbes associated with black band disease of corals. Appl Env Microbiol 75: 2581-2584.

Sussman, M., D. G. Bourne, and B. L. Willis. (2006) A single cyanobacterial ribotype is associated with both red and black bands on diseased corals from Palau. Dis. Aquat. Organ. 69: 111-118.

Suzuki, M., M. S. Rappe, and S. J. Giovannoni (1998) Kinetic bias in estimates of costal picoplankton community structure obtained by measurements of small-subunit rRNA gene PCR amplicon length heterogeneity. Appl Environ Microbiol 64: 4522-4529. 
Swofford, D.L. (1998) PAUP*: Phylogenetic analysis using parsimony (*and other methods), version 4. Sinauer Associates, Sunderland, MA.

Taylor, D.L. (1983) The black band disease of Atlantic reef corals: II. Isolation, cultivation, and growth of Phormidium corallyticum. PSZNI Mar Ecol 4: 321-328.

Thompson, J.D., D. G. Higgins, and T. J. Gibson. (1994) CLUSTAL W: improving the sensitivity of progressive multiple sequence alignments through sequence weighting, position-specific gap penalties and weight matrix choice. Nucleic Acids Research 22: 4673-4680.

Voss, J.D., and L. L. Richardson (2006) Coral diseases near Lee Stocking Island, Bahamas: patterns and potential drivers. Dis Aquat Organ 69: 33-40.

Weil, E. (2004) Coral reef diseases in the wider Caribbean. In Coral health and disease, E. Rosenberg and Y. Loya (Eds). Springer-Verlag, Berlin, Germany, 35-67.

Willis, B.L., C. A. Page, and E. A. Dinsdale (2004) Coral Disease on the Great Barrier Reef. In Coral Health and Disease, E. Rosenberg and Y. Loya (Eds). Springer-Verlag, Berlin, Germany, 69-104. 


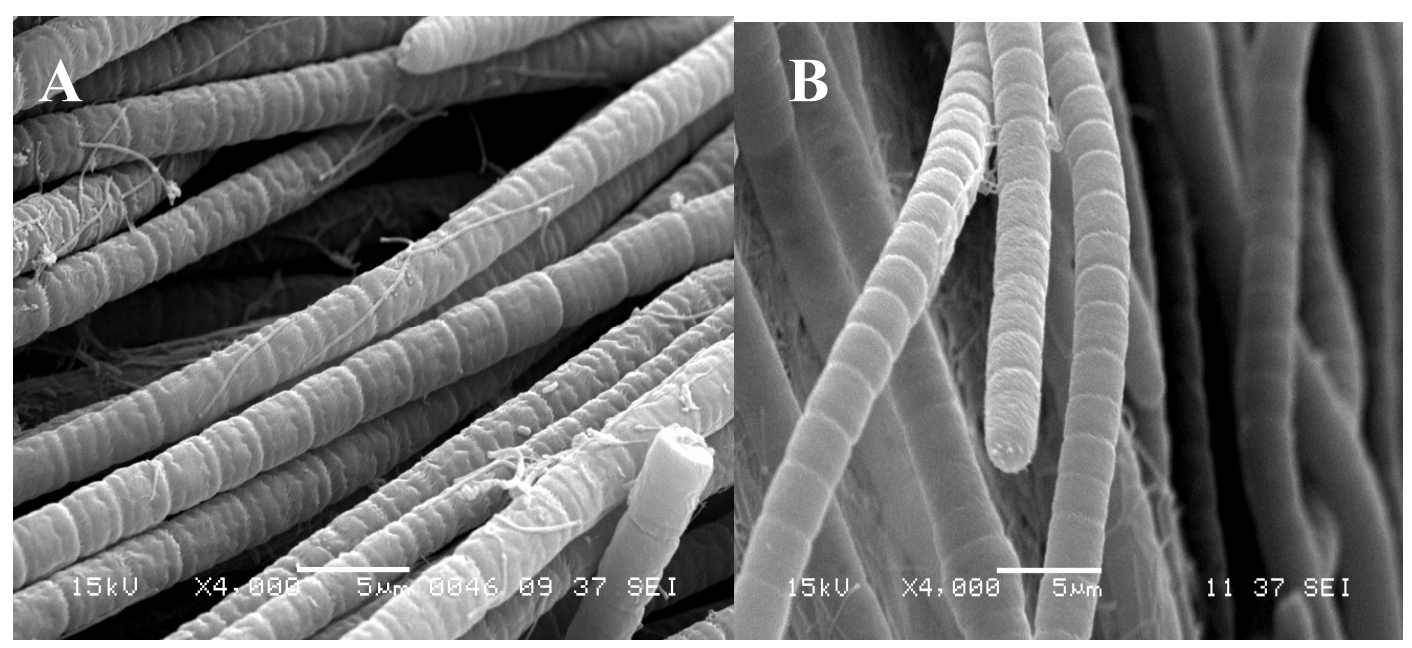

Figure 1. Scanning electron micrographs of Oscillatoria strains 100-1 (A) and 101-1 (B) showing filamentous, non-heterocystous, and unbranched trichomes that are $3.5 \mu \mathrm{m}$ wide and $3.5 \mu \mathrm{m}$ long. 


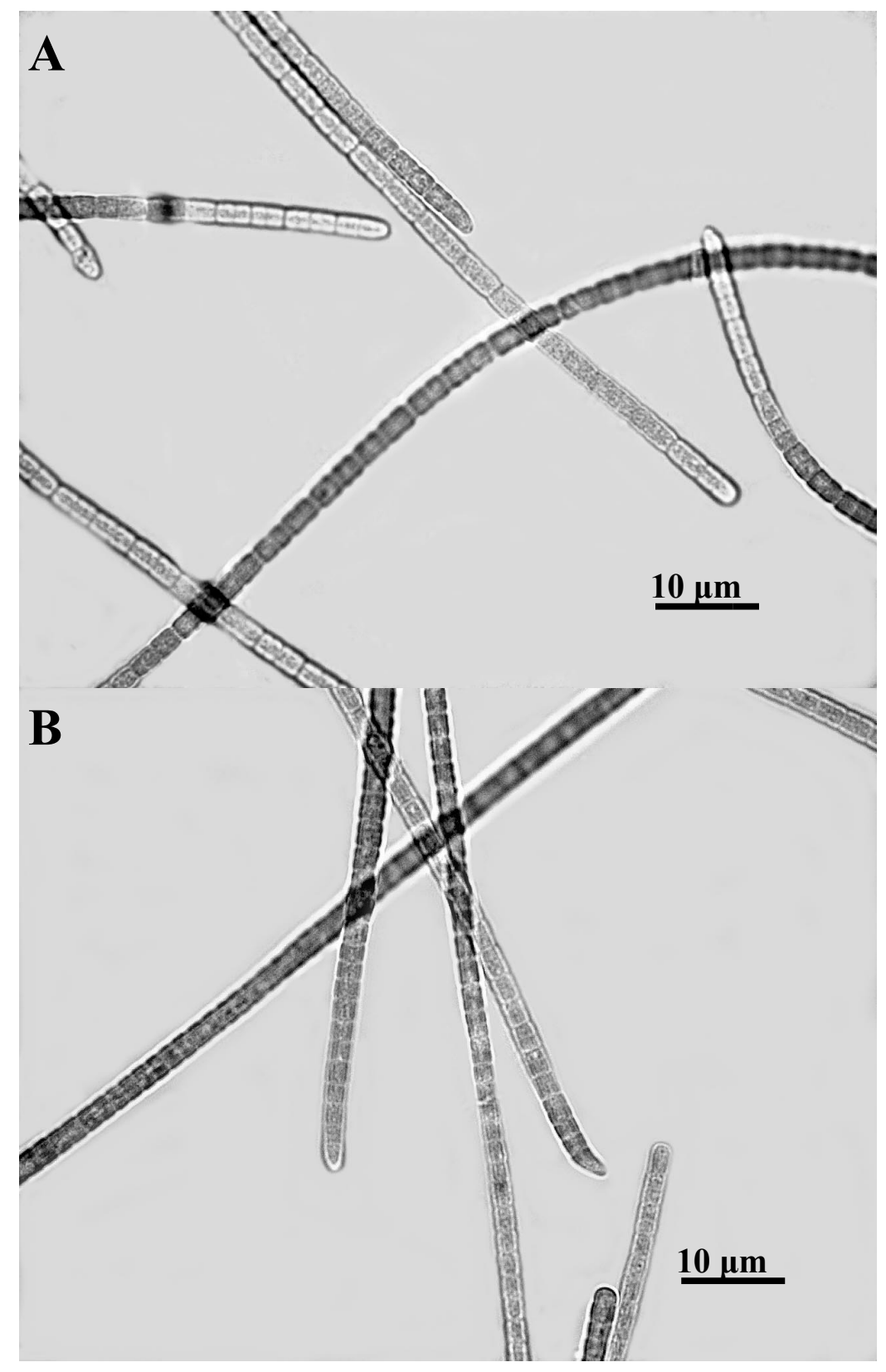

Figure 2. Photomicrographs of Oscillatoria strains 100-1 (A) and 101-1 (B) trichomes with tapering and rounded ends. 

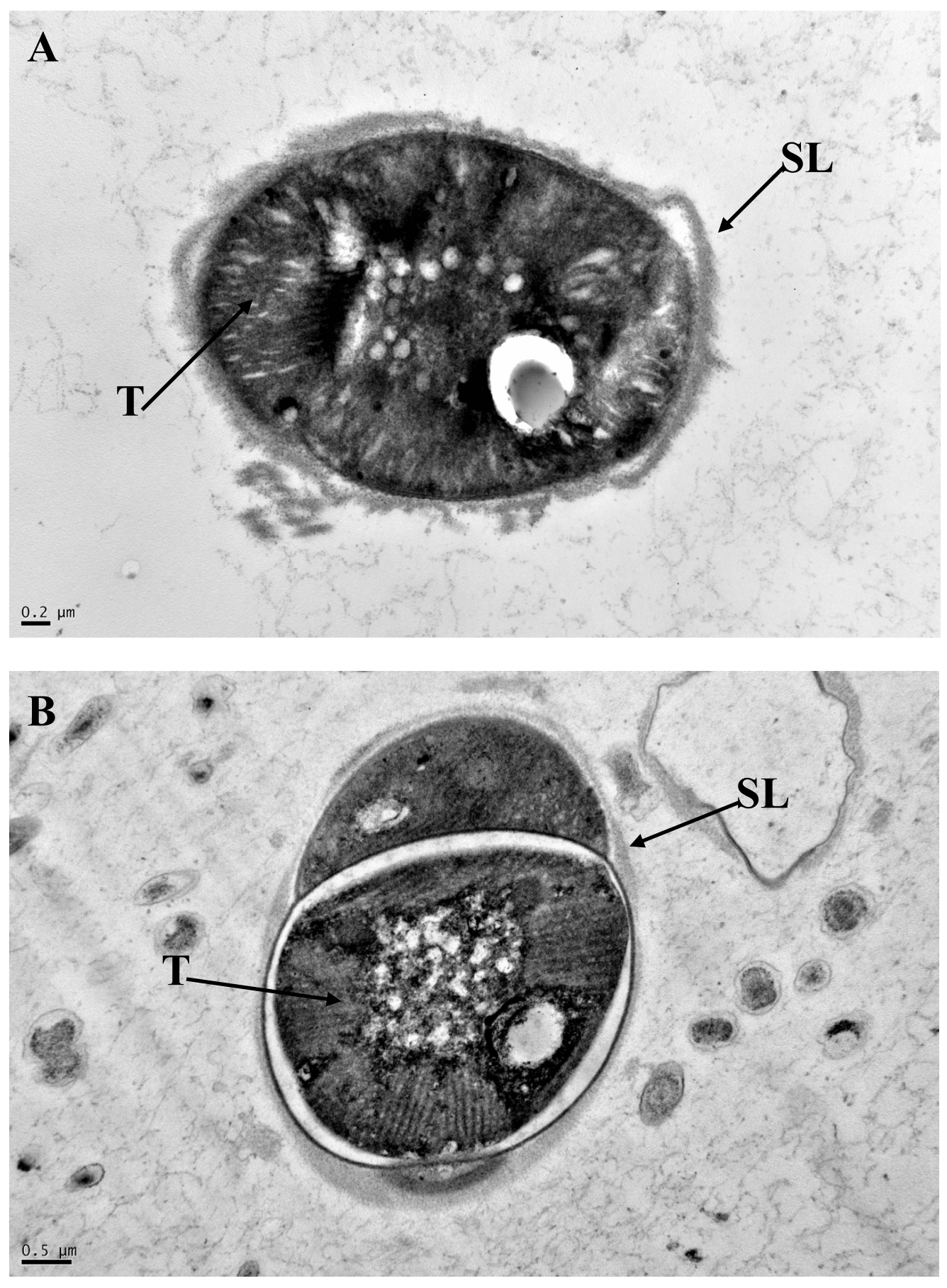

Figure 3. Transmission electron micrographs of Oscillatoria strains 100-1 (A) and 101-1 (B) showing radial thylakoid arrangement (T) and thick sheath layer (SL). 


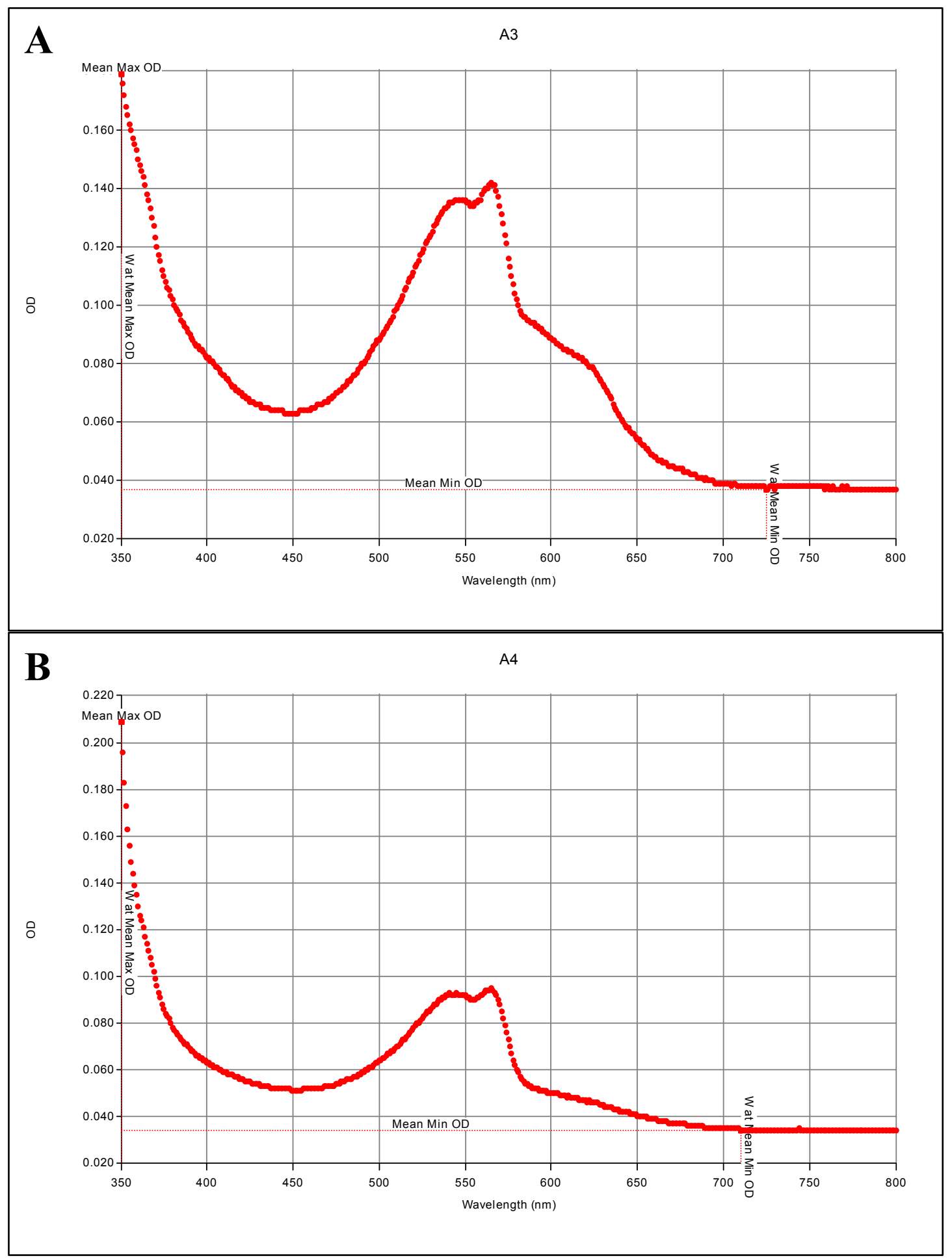

Figure 4. Pigment spectra of Oscillatoria strains 100-1 (A) and 101-1 (B) showing two maximum absorbance peaks at 565 and $548 \mathrm{~nm}$. These peaks are characteristic for phycoerythrin. 

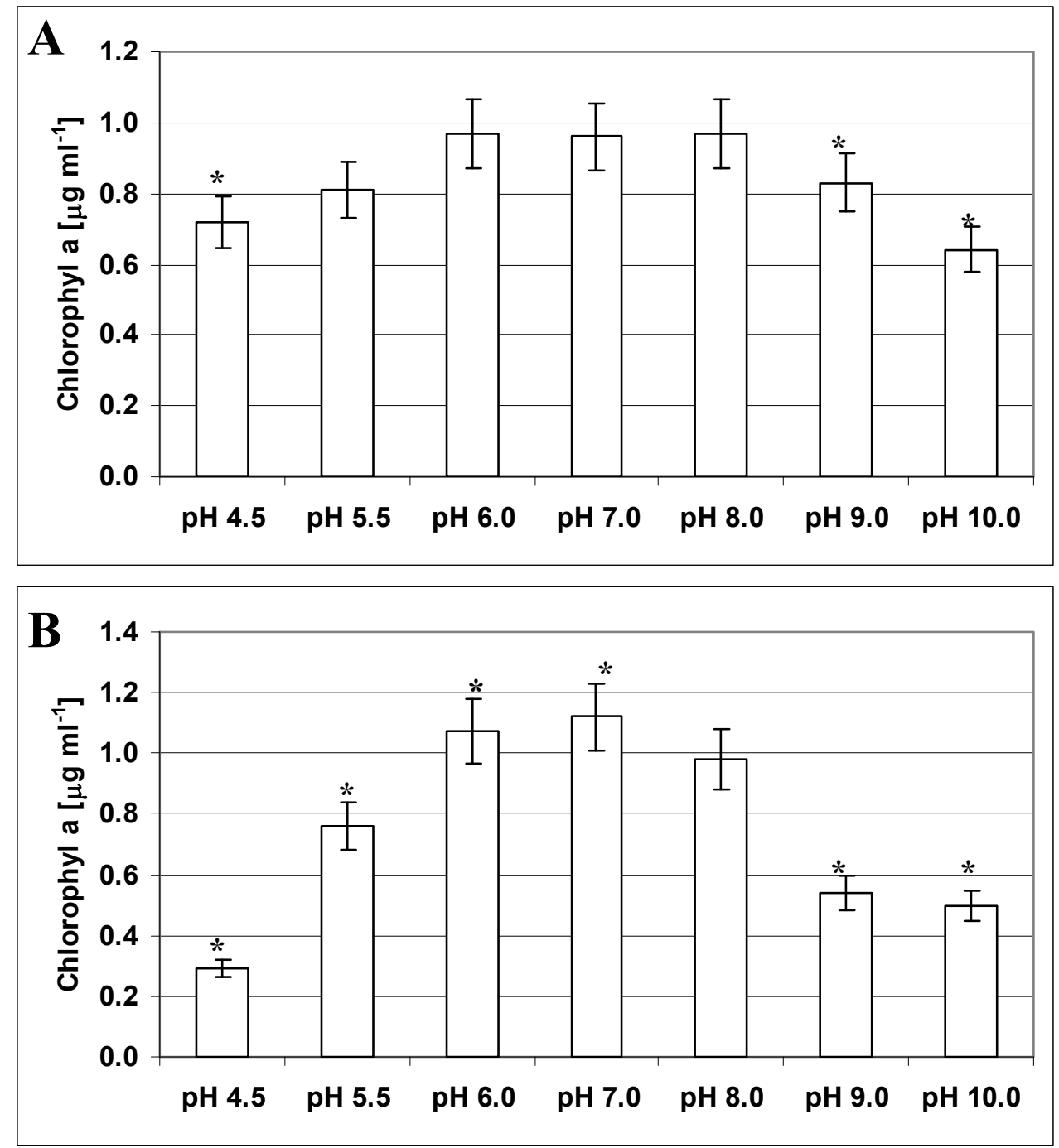

Figure 5. Effect of different pH values on growth of Oscillatoria strains 100-1 (A) and 101-1 (B). Statistical significance, when compared with biomass yield at $\mathrm{pH} 8.0$ is indicated by $*$. 


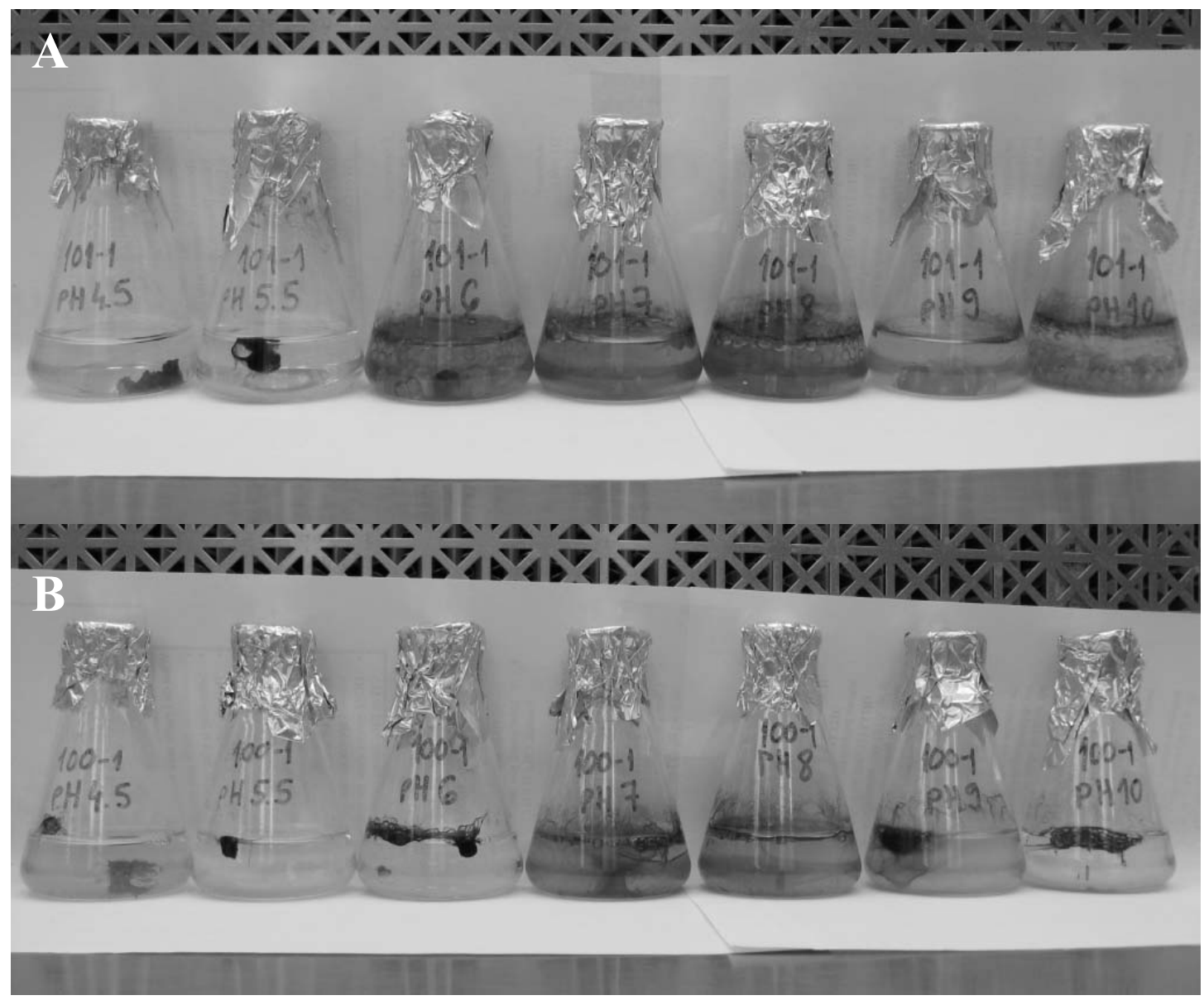

Figure 6. Differences in growth pattern with varying $\mathrm{pH}$ of Oscillatoria strains 101-1 (A) and 100-1 (B). Both Oscillatoria strains formed clumps at lower $\mathrm{pH}$ values (4.5-6.0), but attached to and coated sides of the Erlenmeyer flasks at higher $\mathrm{pH}$ values (7.0-10.0). 
Table 1. Black band disease cyanobacteria isolated into culture and used in this study.

Taxonomic identification was based on 16S rRNA gene sequencing and BLAST search performed on 5/26/2010.

\begin{tabular}{|c|c|c|c|c|}
\hline $\begin{array}{c}\text { Strain } \\
\text { designation }\end{array}$ & $\begin{array}{c}\text { Source (host } \\
\text { coral, reef, region } \\
\text { and sample date) }\end{array}$ & $\begin{array}{c}\text { GenBank } \\
\text { accession no. } \\
\text { (Reference) }\end{array}$ & $\begin{array}{l}\text { Closest relative in } \\
\text { GenBank. Accession } \\
\text { no. }(\% \text { homology })^{1}\end{array}$ & Source \\
\hline $100-1$ & $\begin{array}{c}\text { BBD on } \\
\text { Siderastrea } \\
\text { siderea, St. Croix, } \\
\text { U.S. } \\
\text { Virgin Islands, } \\
6 / 2007\end{array}$ & $\begin{array}{l}\text { HM048872.1 } \\
\text { (This work) }\end{array}$ & $\begin{array}{c}\text { Uncultured } \\
\text { cyanobacterium } \\
\text { EU019487.1 }(97 \%) \\
\begin{array}{c}\text { Uncultured } \\
\text { cyanobacterium }\end{array} \\
\text { EU019480.1 }(97 \%) \\
\text { Oscillatoria } \text { sp. 101-1 } \\
\text { EU743965.1 }(97 \%)\end{array}$ & $\begin{array}{c}\text { BBD from Florida } \\
\text { Keys (US), } \\
\text { Lee Stocking Island } \\
\text { (Bahamas) and St. } \\
\text { Croix (US Virgin } \\
\text { Island) } \\
\text { (Sekar et al., 2009) }\end{array}$ \\
\hline 101-1 & $\begin{array}{c}\text { BBD on Diploria } \\
\text { strigosa, } \\
\text { St. Croix, U.S. } \\
\text { Virgin } \\
\text { Islands, } 6 / 2007\end{array}$ & $\begin{array}{c}\text { EU743965.1 } \\
\text { (Myers and } \\
\text { Richardson, } \\
\text { 2008) }\end{array}$ & $\begin{array}{c}\text { Uncultured } \\
\text { cyanobacterium } \\
\text { EU019515.1 }(99 \%) \\
\begin{array}{c}\text { Uncultured } \\
\text { cyanobacterium }\end{array} \\
\text { EU019499.1 }(99 \%) \\
\begin{array}{c}\text { Uncultured } \\
\text { cyanobacterium }\end{array} \\
\text { EU019496.1 }(99 \%)\end{array}$ & $\begin{array}{l}\text { BBD from Florida } \\
\text { Keys (US), } \\
\text { Lee Stocking Island } \\
\text { (Bahamas) and St. } \\
\text { Croix (US Virgin } \\
\text { Island) } \\
\text { (Sekar et al., 2009) }\end{array}$ \\
\hline
\end{tabular}

${ }^{1}$ Strains $100-1$ and 101-1 were both close matches $(97 \%-99 \%)$ to numerous $(>60)$

cyanobacterial sequences derived from molecular analysis of black band disease deposited as "uncultured cyanobacteria" in GenBank. All of these sequences were identified as most closely related to Oscillatoria by phylogenetic analysis (Sekar et al., 2009). Only the top three matches in the GenBank BLAST searches are listed in the table. 
Table 2. Bacteria isolated from the culture liquid of Oscillatoria 100-1. Taxonomic identification was based on 16S rRNA gene sequencing and BLAST search.

\begin{tabular}{|c|c|l|c|}
\hline Strain & $\begin{array}{c}\text { Sequence length } \\
(\mathrm{bp})\end{array}$ & Closest relative in GeneBank database & Similarity (\%) \\
\hline 100-1B1 & 735 & Pseudomonas sp. (EU883661.1) & 100 \\
\hline 100-1B5 & 770 & Marinobacter sp. (EU440976.1) & 99 \\
\hline 100-1B6 & 747 & Alpha proteobacterium (AB015896.1) & 100 \\
\hline 100-1B7 & 672 & Vibrio sp. (EU372934.1) & 99 \\
\hline 100-1B8 & 750 & Bacillus horikoshii (DQ333286.1) & 99 \\
\hline
\end{tabular}

Table 3. Bacteria isolated from the culture liquid of Oscillatoria 101-1. Taxonomic identification based on 16S rRNA gene sequencing and BLAST.

\begin{tabular}{|l|c|l|c|}
\hline Strain & $\begin{array}{c}\text { Sequence } \\
\text { length (bp) }\end{array}$ & Closest relative in GeneBank database & Similarity (\%) \\
\hline $101-1 \mathrm{~B} 4$ & 754 & Alpha proteobacterium (AB015896.1) & 100 \\
\hline $101-1 \mathrm{~B} 6$ & 754 & Silicibacter sp. (CP000377.1) & 99 \\
\hline $101-1 \mathrm{~B} 7$ & 762 & Erythrobacter sp. (AM990645.1) & 99 \\
\hline $101-1 \mathrm{~B} 8$ & 755 & Mesorhizobium sp. (AY258089.1) & 99 \\
\hline $101-1 \mathrm{~B} 9$ & 753 & Alpha proteobacterium (AB015896.1) & 100 \\
\hline $101-1 \mathrm{~B} 10$ & 737 & Pseudomonas aeruginosa (FJ190080.1) & 100 \\
\hline
\end{tabular}


Table 4. Comparison of the two Oscillatoria strains from this study with the newly described Pseudoscillatoria coralii (FJ210722.2) (Rasoulouniriana et al. 2009).

\begin{tabular}{|l|l|l|l|}
\hline & Oscillatoria 100-1 & Oscillatoria 101-1 & $\begin{array}{l}\text { Pseudooscillatoria } \\
\text { coralii }\end{array}$ \\
\hline $\begin{array}{l}\text { Cell morphology } \\
\text { and dimensions }\end{array}$ & $\begin{array}{l}\text { Cylindrical } \\
3.5 \times 3.5 \mu \mathrm{m}\end{array}$ & $\begin{array}{l}\text { Cylindrical } \\
3.5 \times 3.5 \mu \mathrm{m}\end{array}$ & $\begin{array}{l}\text { Trichome width } \\
5-6 \mu \mathrm{m}\end{array}$ \\
\hline Color of the culture & Dark red/brown & Dark red/brown & Dark green \\
\hline Axessory pigments & Phycoerythrin & Phycoerythrin & Phycocyanin, \\
\hline Optimal pH & $6-8$ & $7-8$ & $7-8$ \\
\hline SEM images & Wrinkled surface & Smooth surface & - \\
\hline $\begin{array}{l}\text { Thylakoid } \\
\text { arrangement }\end{array}$ & Radial & Radial & Radial \\
\hline $\begin{array}{l}\text { Heterotrophic } \\
\text { growth }\end{array}$ & No & No & - \\
\hline Mixotrophic growth & Yes & Yes & - \\
\hline $\begin{array}{l}\text { Formation of } \\
\text { clumps }\end{array}$ & Yes & Yes & - \\
\hline Motility & Yes & Yes & Yes \\
\hline
\end{tabular}



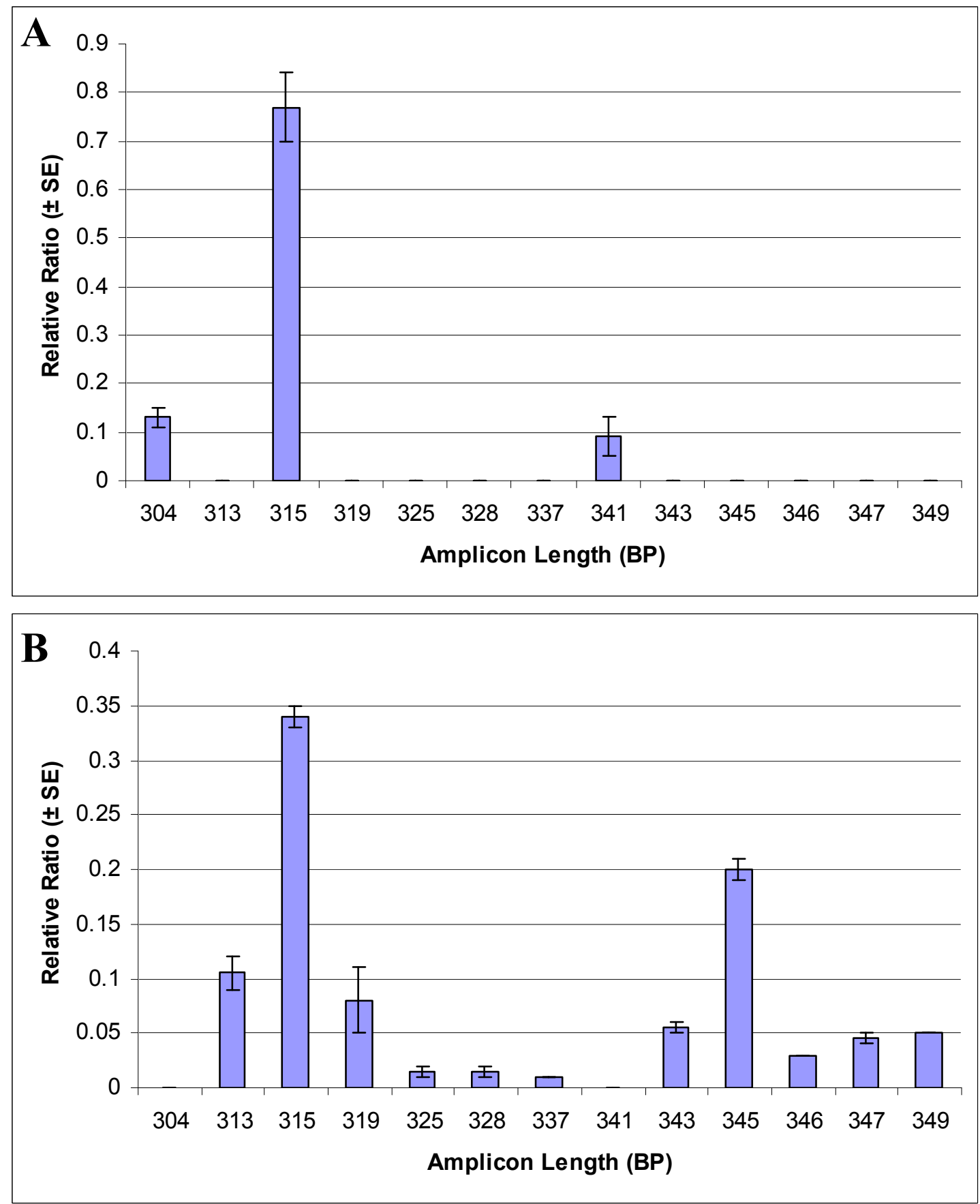

Figure 7. Representative LH-PCR profiles obtained from the cultures of Oscillatoria strains 101-1(A) and 100-1 (B). The LH-PCR profile of strain 100-1 showed higher bacterial diversity in comparison to strain 101-1. 


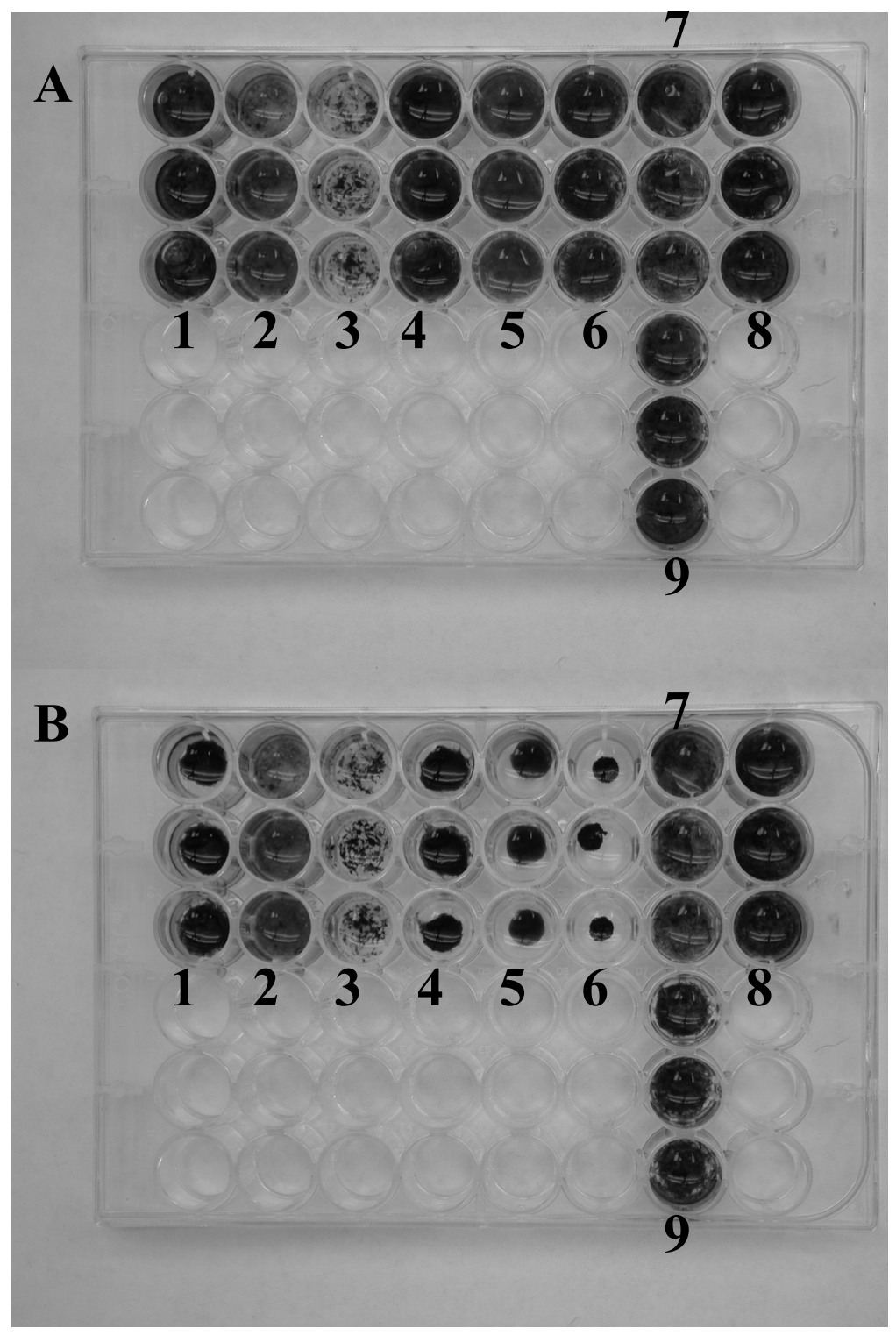

Figure 8. Clumping behavior in the light. Filaments of nine strains $(1-9)$ were dispersed by homogenization. (A) $t=0 ;(B) t=30$ min. Only four of the nine isolates $(1,4,5$ and 6$)$ formed clumps. $(1=$ Geitlerinema $\mathrm{HS}-217 ; 2=$ Leptolyngbya $102 \mathrm{~d}-1 ; 3=$ Leptolyngbya 102e-1; $4=$ Geitlerinema $\mathrm{W}-1 ; 5=$ Oscillatoria $101-1 ; 6=$ Oscillatoria $100-1 ; 7=$ Geitlerinema 1991; 8 = Geitlerinema P2b; 9 = Geitlerinema HS-223). 


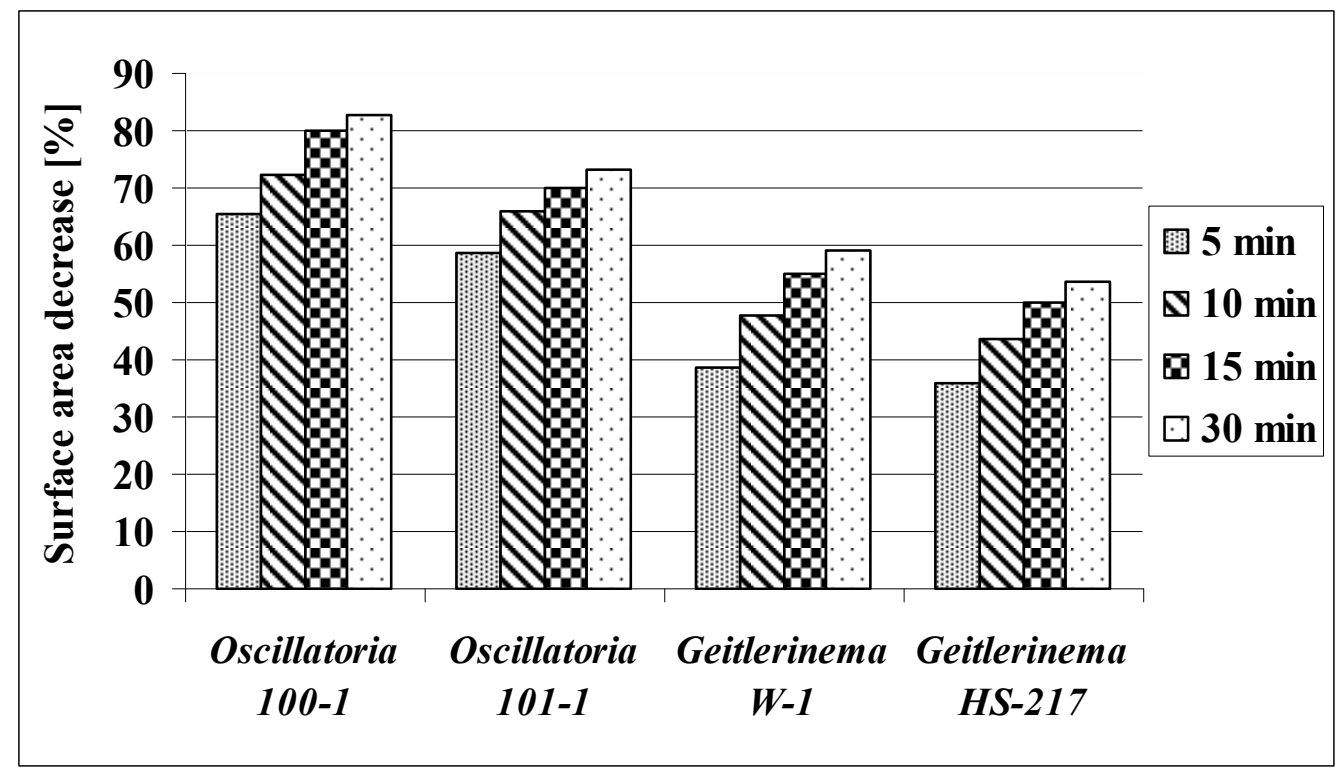

Figure 9. Relative clumping activity (decrease in area from $t=0$ ) of strains that exhibited the ability to form clumps (Figure 8). Oscillatoria strain 100-1 formed the most compact clumps. 


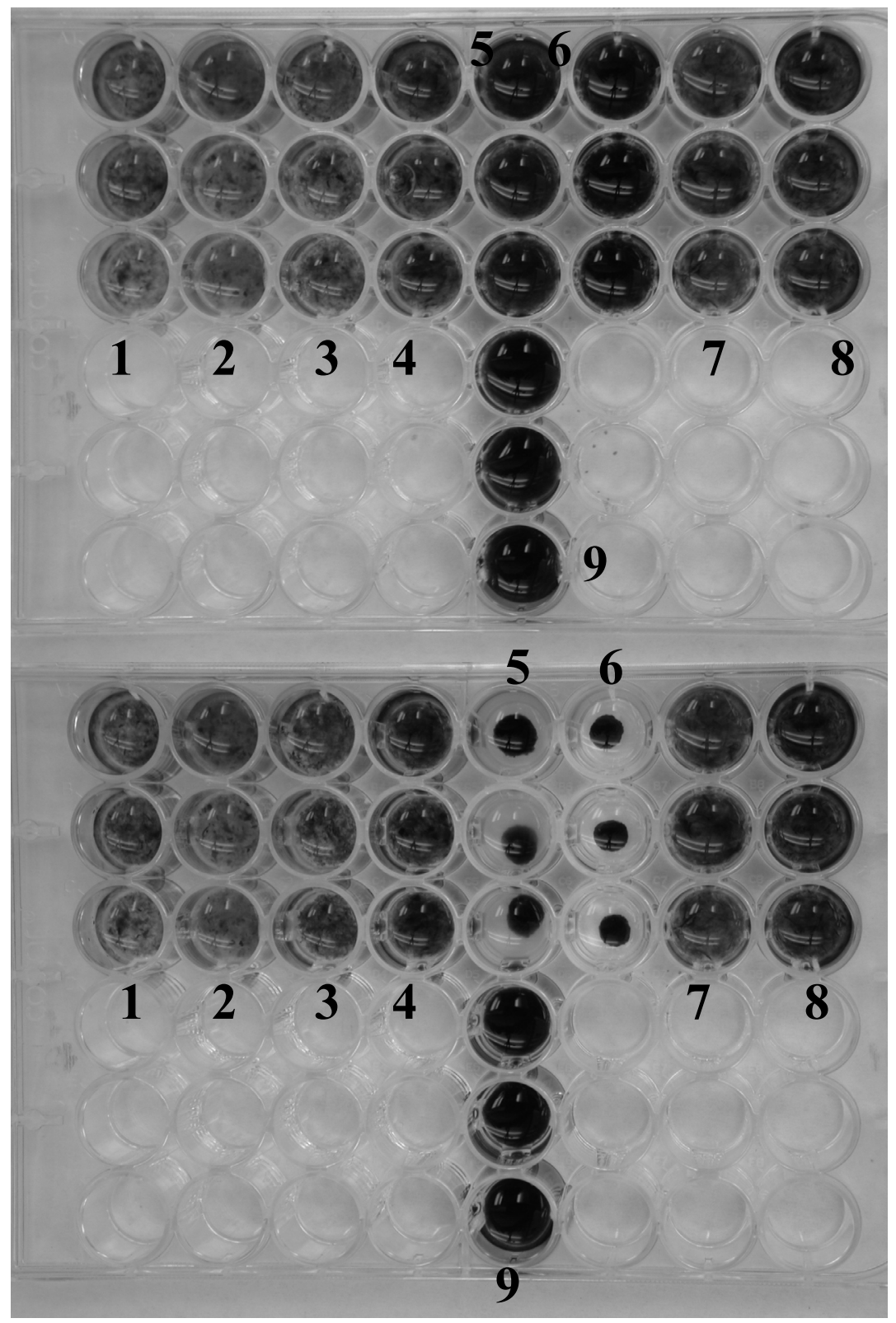

Figure 10. Clumping behavior in the dark. Filaments of nine strains $(1-9)$ were dispersed by homogenization. (A) $\mathrm{t}=0 ;(\mathrm{B}) \mathrm{t}=30 \mathrm{~min}$. Only two Oscillatoria strains ( 5 and 6) out of nine cyanobacterial isolates formed clumps. (1=Geitlerinema HS-217; 2= Leptolyngbya 102d-1; 3=Leptolyngbya 102e-1; 4=Geitlerinema $\mathrm{W}-1 ; 5=$ Oscillatoria 101-1; 6=Oscillatoria $100-1 ; 7=$ Geitlerinema $1991 ; 8=$ Geitlerinema $\mathrm{P} 2 \mathrm{~b} ; 9=$ Geitlerinema HS-223) 


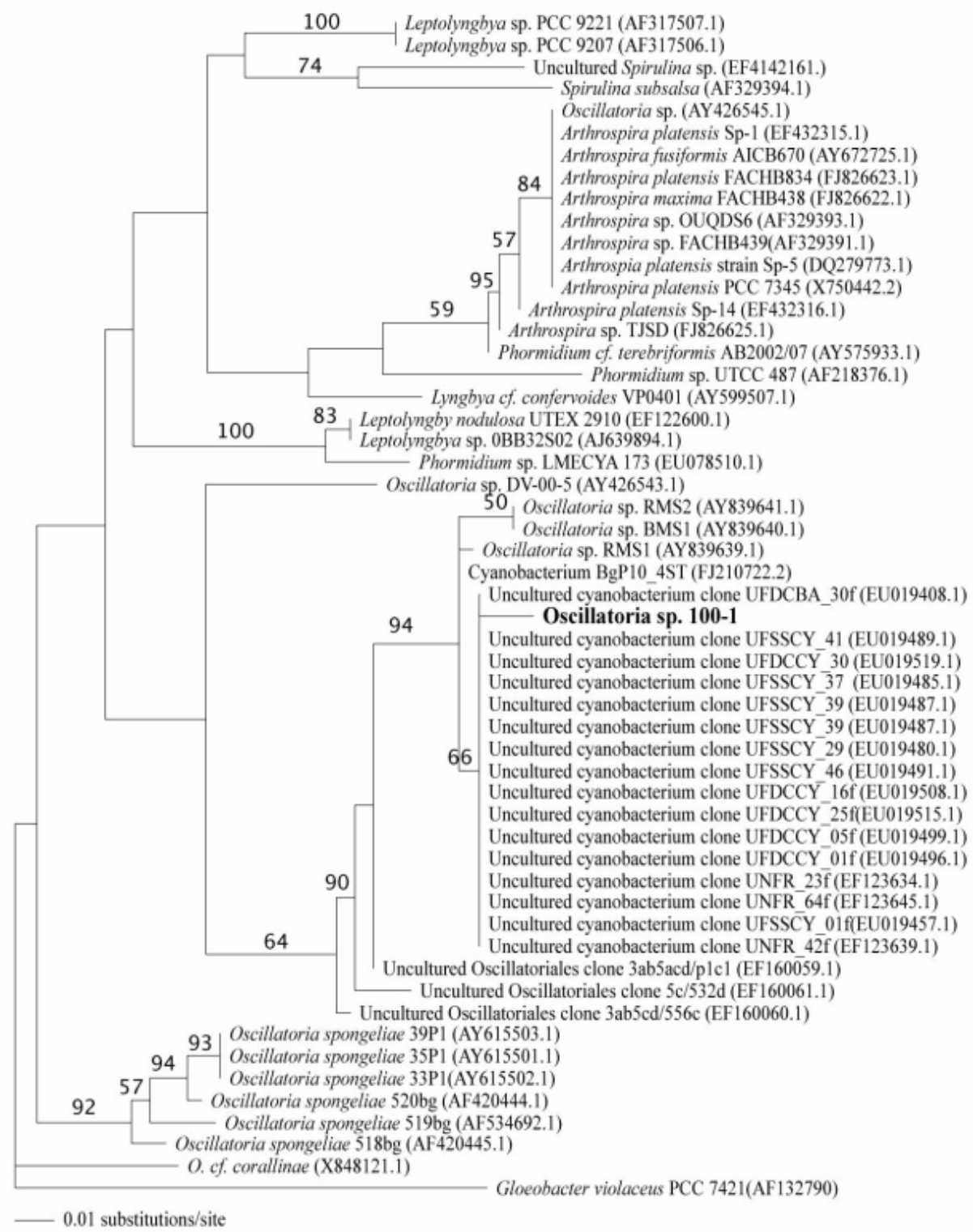

Figure 11. Phylogenetic tree derived from the 16S rRNA gene sequence of Oscillatoria strain 100-1 and its most closely related neighbors. The tree topology is based on maximum likelihood analysis. Scale bar corresponds to $1 \%$ estimated sequence divergence. 
CHAPTER III.

MICROCYSTIN PRODUCTION AND ECOLOGICAL PHYSIOLOGY OF THE

CARIBBEAN BLACK BAND DISEASE CYANOBACTERIUM OSCILLATORIA

SP.

\begin{abstract}
Black band disease (BBD) of corals is one of the major factors contributing to the recent decline of coral cover and diversity worldwide. This pathogenic microbial consortium is dominated by phycoerythrin-rich, gliding, filamentous non-heterocystous cyanobacteria. It is well known that cyanobacteria are capable of toxin production, which has been documented in a number of freshwater species. However, toxin production has not been investigated to the same extent in marine species. Recently, it was shown that BBD cyanobacteria are capable of toxin production. I proposed that the sulfide-rich, anaerobic condition within the BBD mat, together with toxin produced by cyanobacteria, are mechanisms contributing to the pathobiology of BBD. In this work, two strains of Oscillatoria, isolated from BBD, were tested for their ability to produce toxins. Extracts of these laboratory grown cyanobacteria were assessed for the presence of toxins by using ELISA and their identification was carried out using Ultra-Performance Liquid Chromatography-Tandem Quad Mass Spectrometry (UPLC-MS/MS). Results showed that both cyanobacterial strains produce microcystin-LR (MC-LR). Additionally MC-LR production was assessed by one Oscillatoria strain under different environmental conditions.
\end{abstract}




\section{Introduction}

Coral diseases are one of the major factors contributing to the recent decline of coral cover and diversity (Hughes et al., 2003; Pandolfi et al., 2003). It has been suggested that approximately 30 different diseases affect corals worldwide (Green and Bruckner, 2000; Sutherland et al., 2004) of which 18 have been characterized to date (Sutherland et al., 2004). Black band disease is one of the major diseases affecting corals world wide (Carlton and Richardson, 1995). The disease appears as a horizontally migrating dark-colored band that ranges in width from $1 \mathrm{~mm}$ to a few centimeters and migrates across the tissue of corals at a rate as fast as $1 \mathrm{~cm}$ per day killing healthy tissue and leaving behind dead skeletal surface (Antonius, 1981; Richardson, 1996; Richardson, 1998). It has been characterized as a microbial mat dominated by phycoerythrin-rich, gliding, filamentous non-heterocystous cyanobacteria (Antonius, 1973; Rützler et al., 1983; Taylor, 1983; Richardson et al., 1997; Richardson and Kuta, 2003). In addition to a spatially dominant cyanobacterial population this pathogenic microbial consortium (Richardson, 2004) contains sulfide-oxidizing bacteria of the genus Beggiatoa (Garrett and Ducklow, 1975; Ducklow and Mitchell, 1979), sulfate reducing bacteria (Cooney et al., 2002; Viehman et al., 2006 ), numerous heterotrophic bacteria (Cooney at al., 2002; Frias-Lopez et al., 2002; Frias-Lopez et al., 2004; Sekar et al., 2006), and marine fungi (Ramos-Flores, 1983).

The physiology of microbial mat and BBD microorganisms is complex and dynamic. Many mat cyanobacteria can switch between oxygenic and anoxygenic photosynthesis (Jörgensen et al., 1986) and between aerobic respiration and fermentation (Richardson and Castenholz, 1987). A study using oxygen and sulfide microelectrodes 
revealed that the surface of the BBD mat is oxygenated while the base of the mat is anoxic and sulfide rich, with the presence of a vertically migrating oxygen/sulfide interface depending upon light intensity (Carlton and Richardson, 1995). The sulfide-rich condition within the band was shown to be a mechanism of BBD pathobiology (Richardson et al., 1997). Some cyanobacteria produce low molecular weight toxins that can kill fish and other animals during blooms (Codd et al., 1997). Recently, the Richardson/Gantar laboratory showed that cyanobacteria within BBD produce cyanotoxin, which along with anoxia and the sulfide-rich interior of black band contributes to the overall pathobiology of BBD (Richardson et al., 2007, 2009; Gantar et al., 2009).

In the present study I investigated two recently isolated BBD cyanobacterial strains that belong to the genus Oscillatoria (strains 100-1 and 101-1). According to molecular studies of the microbial community of BBD, Oscillatoria has been identified as a consistent member in BBD samples from distant geographical regions (Frias-Lopez et al., 2003; Barneah et al. 2007; Myers et al. 2007).

\section{Materials and Methods}

\section{Experimental organisms}

My BBD samples were collected on reefs of St. Croix, US Virgin Islands, and of the Northern Florida Keys using sterile, needleless $10 \mathrm{ml}$ syringes while SCUBA diving. Sample sites, host species, date of sampling, and sample designations referred to in this study are presented in Table 1.

Cyanobacteria were isolated from BBD using the gliding method described by Castenholz (1988). The method involves point inoculation of ASNIII and/or BG11 
(Rippka et al., 1979) agar plates with a BBD cyanobacterial sample. After $24 \mathrm{~h}$ a dissecting microscope (Motic SMZ-140, Grasonville, MD, USA) was used to locate cyanobacterial filaments that had glided out from the initial point of inoculation.

Filaments were cut out of the agar using sterile watchmaker's forceps and transferred to tubes containing $10 \mathrm{ml}$ of liquid ASN III medium.

Laboratory cultures were maintained in ASNIII and marine BG11 liquid media at $27^{\circ} \mathrm{C}$ and $30 \mu \mathrm{Em}^{-2} \mathrm{~s}^{-1}$ under $24 \mathrm{~h}$ of constant cool-white light regime (Philips, F34T12/CW/RS/EW). Cultures were transferred every three weeks to fresh culture media.

\section{Taxonomic identification of cyanobacterial isolates}

Taxonomic identification of BBD cyanobacterial isolates was based on PCR amplification and sequencing of the $16 \mathrm{~S}$ rRNA gene. The cyanobacteria specific primers CYA359F and CYA781R(b) (Nübel et al., 2007) were used for PCR amplification. Methods used for isolation of total genomic DNA, 16S rRNA gene amplification, and sequencing are detailed elsewhere (Myers et al., 2007). Sequences obtained in this study were manually edited using FinchTV version 1.4.0 (Geospiza, Seattle, WA, USA) and assembled using ContigExpress (Invitrogen, Carlsbad, CA, USA). For the identification of their closest relatives sequences were analyzed using the BLAST search (http://www.ncbi.nlm.nih.gov/BLAST/) (Altschul et al., 1990).

\section{Quantification of toxin production}

Toxins produced by each of the two cyanobacterial isolates were assayed using cell extracts and Enzyme Linked Immunosorbent Assay (ELISA) (Carmichael and An, 1999). Microcystin-DM ELISA kits were purchased from Abraxis (Warminster, PA, 
USA). The ELISA kit is a congener independent assay for microcystins and nodularins (Fisher et al., 2001) and cannot distinguish between these two toxins or between microcystin variants. Toxin concentrations were calculated as micrograms of microcystin-LR (MC-LR) equivalent in $1 \mathrm{~g}$ of dry cyanobacterial biomass. Purified MCLR was used as a standard.

Sufficient biomass of the cyanobacterial test strains required for toxin analysis was obtained by growing cultures in 4 L flasks in ASNIII medium, with aeration with sterile air and continuous illumination with cool-white fluorescent light at $30 \mu \mathrm{E} \mathrm{m} \mathrm{m}^{-2}$. The cultures were grown for four weeks after which the biomass was harvested by centrifugation and freeze-dried. Cell extracts were prepared by extracting $100 \mathrm{mg}$ of dry biomass in $10 \mathrm{ml}$ of distilled water overnight at $4{ }^{\circ} \mathrm{C}$. After centrifugation, the supernatant was filtered through a membrane filter $(0.45 \mu \mathrm{m}$ pore size $)$ and used for ELISA.

Standards and samples were run in triplicates.

\section{Effect of environmental factors on toxin production}

The effect of different environmental factors relevant to coral reefs on toxin production was tested using Oscillatoria sp. strain 101-1. This particular strain was selected because it produced more toxin than the other strain tested (Table 2). To obtain sufficient biomass the culture was grown in triplicate in 4 L flasks of ASNIII medium (Rippka et al., 1979) with aeration under cool-white fluorescent light at $27^{\circ} \mathrm{C}$. The biomass was harvested after four weeks as described above, resuspended in $600 \mathrm{ml}$ of ASNIII medium, and homogenized using a hand-held homogenizer for $30 \mathrm{~s}$ to get a uniform suspension of filaments. Inocula $(50 \mathrm{ml})$ provided a starting biomass of approximately $0.5 \mathrm{mg} \mathrm{ml}^{-1}$ of dry weight. In order to determine the effect of different 
environmental factors on toxin production Oscillatoria strain 101-1 was grown at: (1) two different temperatures, $27^{\circ} \mathrm{C}$ (control) and $30^{\circ} \mathrm{C}$; (2) in the presence of glucose and fructose in the light; (3) in the presence of glucose and fructose in the dark; (4) in anaerobic conditions in dark in the presence of $\mathrm{Na}_{2} \mathrm{~S}$ with the addition of glucose and fructose; and (5) at three $\mathrm{pH}$ values $(\mathrm{pH} 5.5, \mathrm{pH} 7.0$ and $\mathrm{pH} 9.0)$. Solutions of glucose and fructose were filter sterilized and added to ASN III medium for a final concentration of $10 \mathrm{mM}$. Anaerobic conditions were obtained by flushing the initial culture with a stream of $100 \%$ reagent grade $\mathrm{N}_{2}$ gas for 30 min. Flasks were sealed and $\mathrm{Na}_{2} \mathrm{~S} \cdot 9 \mathrm{H}_{2} 0$ was injected through the septum for a final concentration of $0.5 \mathrm{mM}$. Cultures were maintained, if not stated otherwise, at $27^{\circ} \mathrm{C}$ and $30 \mu \mathrm{Em}^{-2} \mathrm{~s}^{-1}$ under $24 \mathrm{~h}$ of constant cool-white light and $\mathrm{pH}$ 8. Every second day the $\mathrm{pH}$ was checked and, if needed, adjusted using $10 \% \mathrm{HCl}$. For cultures grown at $30^{\circ} \mathrm{C}\left( \pm 0.3^{\circ} \mathrm{C}\right)$ flasks were partially submerged in a temperaturecontrolled aquarium. Temperature was monitored using a calibrated laboratory thermometer. A double layer of aluminum foil was used to wrap the cultures grown in the dark. All cultures were hand-shaken twice a day.

After one week the cultures were centrifuged, the biomass freeze-dried, and the dry weight recorded. The extracts for ELISA were prepared in the same way as described above. This experiment was repeated three times, in triplicate, and the data presented as the means of the three experiments.

\section{Toxin identification}

For toxin identification the biomass of cyanobacteria was obtained in the same way as described above. Cell extracts were prepared by extracting $5 \mathrm{~g}$ of dry biomass in $500 \mathrm{ml}$ of distilled water for $24 \mathrm{~h}\left(4^{\circ} \mathrm{C}\right)$. Extracts were then centrifuged and filtered 
through GF/F filters (Whatman, Maidstone, UK). Solid phase extraction was performed on a C-18 column (Alltech Associates Inc, Deerfield, Ill, USA), eluted with 70\% methanol. The elute was then evaporated to dryness.

Ultra Performance Liquid Chromatography $\left(\mathrm{UPLC}^{\circledR}\right)$ was performed with a Waters Acquity LC-MS/MS system (Waters Corporation, MA, USA). Using a previously described method (Oehrle et al., in press) the analysis provides for separation of the 10 cyanotoxins: anatoxin- $a$, cylindrospermopsin, nodularin, and seven MC congeners (RR, YR, LR, LA, LY, LW and LF). The MS/MS, equipped with a Tandom Quadrupole (TQ) detector (Waters), analyzes the various toxins via Multiple Reaction Monitoring( MRM), which monitors specific precursor and fragment ions (product ions) for each analyte. The mass spectrometer was operated in electrospray positive mode.

Analyte separation was achieved on an Acquity UPLC HSS T3 column (100 mm x $2.1 \mathrm{~mm}$, i.d., $1.8 \mu \mathrm{m}$ particle size, $130 \AA$ Å pore size, Waters Corporation) maintained at $35^{\circ} \mathrm{C}$. A 12 min binary gradient was used employing a $0.1 \%$ formic acid (aqueous) and $0.1 \%$ formic acid (acetonitrile) mobile phase at a flow rate of $0.45 \mathrm{ml} / \mathrm{min}$. The acidified acetonitrile was initially run at $2 \%$ for $0.80 \mathrm{~min}$ and then increased to $70 \%$ over 9 min, washed with $80 \%$ acetonitrile for $1 \mathrm{~min}$, and returned to $2 \%$ for $2 \mathrm{~min}$ prior to the next injection. Figure 1 shows the separation of a standard mix of all the compounds screened. The samples were prepared by taking approximately $0.02 \mathrm{~g}$ of material and dissolving it in $1 \mathrm{ml}$ of methanol. This solution was than diluted 1:1 with high purity water, filtered and analyzed by UPLC/MS/MS. 


\section{Statistical analysis}

Statistical analyses were performed using the software SPSS version 11.0. The significance between different treatments (growth and MC production in different environmental conditions) was tested by one way ANOVA and Bonferroni multiplecomparisons test.

\section{Results}

\section{Experimental organisms}

Cyanobacteria used in this study originated from samples of BBD collected at two different geographical regions in the wider Caribbean and from three different coral host species (Table 1). One of the Oscillatoria strains was the subject of previous research in related studies of BBD (see Table 1). The second Oscillatoria strain, 101-1, was newly isolated and identified based on morphological features, 16S rRNA gene sequencing, and a BLAST search within GenBank.

\section{Toxin production and identification}

The results obtained by ELISA showed that cell extracts of both strains had measurable levels of toxicity (Table 2). The toxin content per cyanobacterial biomass varied between 0.17 and $0.27 \mu \mathrm{g} \mathrm{MC} \mathrm{g}^{-1}$ and was found to be the highest for Oscillatoria strain 101-1.

Identification of MCs carried out by UPLC-MS/MS analysis showed that both cyanobacterial strains produced the MC-LR variant. A representative separation of a standard of all of the screened toxins is shown in Figure 1. In this figure, each individual trace was stacked to enable comparison of peaks. The separation and screening for all 10 toxins was accomplished in a single 12 minute run. A representative MC-LR peak 
separation, for Oscillatoria strain 101-1, is shown in Figure 2. The other cyanotoxins separated by the UPLC-MS/MS assay, specifically anatoxin- $a$, nodularin, cylindrospermopsin, and the MC congeners RR, LA, LY, LW and LF, were not detected.

\section{Growth and toxin production under different environmental conditions}

The effect of environmental factors on toxin production and growth was tested in Oscillatoria strain 101-1 (Figure 3). A significantly higher biomass yield was obtained in the presence of fructose and glucose under light conditions $(\mathrm{P}<0.02)$, while cultivation in darkness, in media supplemented with either glucose or fructose undere both aerobic and anaerobic conditions caused bleaching and lysis of the culture. Microcystin production was not significantly affected by the different environmental conditions, except for those in darkness, which showed a lower level of MC per unit biomass.

\section{Discussion}

Previous work showed that cyanobacteria from BBD belonging to the genera Leptolyngbya, Geitlerinema, and Spirulina, are capable of producing cyanotoxins (Richardson et al., 2007; Gantar et al., 2009), and Richardson et al. (2007) have detected cyanotoxins in BBD field samples. Richardson et al. (2009) have also shown that exposure of healthy coral fragments to purified MC-LR results in tissue lysis and death. Here I add to the previous work on cyanotoxin production in BBD cyanobacteria by further investigation of two isolates of the apparently ubiquitous BBD cyanobacterium Oscillatoria sp. I believe that these isolates deserve special attention because (i) the $16 \mathrm{~S}$ rRNA sequence corresponding to this Oscillatoria appears to be a consistent member of BBD consortia on reefs world-wide (Frias-Lopez et al., 2003; Barneah et al. 2007; Myers et al., 2007) and (ii) because I have shown that these isolates (Oscillatoria 100-1 and 
101-1) are capable of initiating an infection in coral fragments in controlled laboratory conditions (Chapter IV).

This study showed that the two strains of Oscillatoria produce MC-LR. These findings are in agreement with earlier work in which it was found, using HPLC/MS, that cultures of the BBD Geitlerinema 1991 strain and another strain, BBD Leptolyngbya, produced MC-LR (Richardson et al., 2007). In this study field samples of BBD collected from reefs of the Northern Florida Keys and Lee Stocking Island, Bahamas, were also assayed using HPLC/MS. Microcystins was present in 22 field samples from nine reefs in these two regions, with different variants detected - specifically, -LA, -LF, -LY, -LW, RR and -LR in the Bahamas samples and -LY in the Florida samples (Richardson et al., 2007). In the Bahamas samples, in addition to the three host coral species associated with the present study (Siderastrea siderea, Montastraea annularis and Diploria strigosa) BBD from Colphophyllia natans was assayed. In contrast to the present study, in which the two isolates from the Florida Keys were from BBD on the coral hosts Siderastrea siderea and Diploria strigosa, the previous study utilized BBD from a different host, Meandrina meandrites. Therefore the detection of more variants in the previous study could be influenced in part by different coral host species. It is known that individual strains of cyanobacteria can synthesize different variants of microcystin, and that the environment can determine which variants are expressed (see, for example, Lee et al., 2000). Therefore, even though to date only two variants have been detected (MCLR and MC-LY) in five laboratory cultures of BBD cyanobacteria (Geitlerinema, Leptolyngbya and Oscillatoria) there very well may be an environmental signal within 
the BBD microenvironment that induces BBD cyanobacteria to synthesize additional variants.

Microcystins are the most common type of toxin produced by cyanobacteria (Chorus and Bartram, 1999). Microcystins comprise a group of over 80 structural variants of cyclic heptapeptides (Dietrich and Hoeger, 2005). The most toxic and most studied microcystin variant is MC-LR. This is a known hepatotoxin that in vertebrates specifically affects liver cells. The most apparent effect in hepatocytes is morphological transformation of microtubules (Falconer and Yeung, 1992.), a process that is initiated through inhibition of the protein phosphatases PP1 and PP2A (Lankoff et al., 2003). Oxidative stress has also been shown to play role in MC induced cytotoxicity (Moreno et al., 2005). It has been observed that MC induces DNA oxidative damage (Žegura et al., 2003) and that sublethal doses of MC-LR can result in hepatocellular apoptosis (Guzman and Solter, 2002). A considerable amount of information is available on the effects of microcystin on human and vertebrate hepatocytes, however little is known about its effect on invertebrate organisms.

Recently, Richardson et al. (2009) demonstrated that when apparently healthy coral fragments were exposed to purified MC-LR there was a degradation of the structural integrity of the coral epidermis and gastrodermis together with extrusion of zooxanthellae from their normal location in the gastrodermis (Richardson et al., 2009). These effects were enhanced during co-exposure of coral fragments to both MC-LR and sulfide. These experiments confirmed earlier hypothesis that cyanotoxins produced by cyanobacteria within $\mathrm{BBD}$, along with the anoxic and sulfide-rich $\mathrm{BBD}$ microenvironment, contribute to BBD pathobiology (Richardson et al., 2009). 
Microcystin may play an additional role in BBD etiology. Purified MC-LR not only affects coral tissue, but the growth of heterotrophic bacteria isolated from BBD was relatively more stimulated by MC-LR than growth of bacteria that were isolated from the surface mucopolysacchride layer of healthy corals (Richardson et al., 2009). Thus microcystin may play a role in structuring the complex polymicrobial composition of BBD.

Cyanobacteria, together with the other members of the BBD microbial community, are subjected to widely varying environmental conditions within the BBD microbial mat (Carlton and Richardson 1995). Since it is known that cyanotoxin production can be affected by various environmental factors such as light (Wiedner et al., 2003), temperature (Van der Westhuizen and Eloff, 1985), and nutrients (Lee et al., 2000), I assessed the effect of some environmental conditions that can be associated with the BBD environment on toxin production. These experiments revealed that the growth of Oscillatoria strain 101-1 was significantly higher in light conditions when the medium was supplemented with glucose and fructose, which agrees with our previous findings for BBD strains belonging to the genera Leptolyngbya and Geitlerinema (Gantar et al., 2009). However, there was no growth in darkness, and bleaching and lysis of the culture was observed under these conditions. This is contrary to what was found for Geitlerinema and Leptolyngbya in a previous study (Gantar et al., 2009) in which these two strains showed the ability to grow both mixotrophycally and heterotrophically. Therefore, BBD Oscillatoria may not be able to take advantage of the organic carbon liberated during coral tissue lysis associated with BBD. 
Microcystin production by BBD Oscillatoria strain 101-1 was not significantly affected by any of the environmental conditions tested, except for dark aerobic and dark anaerobic conditions in which there was significantly lower level of the toxin. This is understandable since under these conditions lysis of biomass was observed. Higher temperature $\left(30^{\circ} \mathrm{C}\right)$ decreased (not significantly) $\mathrm{MC}$ production in relation to the $27^{\circ} \mathrm{C}$ control, which is in accordance with our earlier findings for Geitlerinema and Lepotolyngbya (Gantar et al., 2009) and other toxic cyanobacteria (Van der Westhuizen and Eloff, 1985).

In conclusion, the present study showed that two Oscillatoria strains tested are capable of producing MC-LR, the most toxic variant of microcystin. None of the strains produced any of the eight additional toxins assayed in previous studies using UPLCMS/MS (anatoxin- $a$, cylindrospermopsin, nodularin, MC-RR, -LA, -LY, -LW and -LF). These results are in agreement with earlier work in which HPLC/MS was used and where anatoxin- $a$ or saxitoxin were not detected in BBD field samples or BBD cyanobacterial cultures. However, in the same work multiple MC variants in BBD field samples and MC-LR in BBD cyanobacterial cultures were detected (Richardson et al., 2007). It appears that production of the very toxic MC-LR is a universal feature of cyanobacteria associated with BBD and an important part of BBD etiology. It is possible that additional microcystin variants are synthesized within the BBD mat environment. 


\section{REFERENCES}

Altschul, S. F., W. Gish, W. Miller, E. W. Meyers, and D. J. Lipman (1990) Basic local alignment search tool. J Mol Biol 215: 403-410.

Antonius, A. (1973) New observations on coral destruction in reefs. 10th Meeting Association of Island Marine Laboratories of the Caribbean 10: 3.

Antonius, A. (1981) The 'band' diseases in coral reefs. Proceedings of the Fourth International Coral Reef Symposium. 2: 7-14.

Barneah, O., E. Ben-Dov, E. Kramarsky-Winter, and A. Kushmaro (2007)

Characterization of black band disease in Red Sea stony corals. Environ Microbiol 9:

1995-2006.

Carlton, R. G., and L. L. Richardson (1995) Oxygen and sulfide dynamics in horizontally migrating cyanobacterial mat: black band disease of corals. FEMS Microbiol Ecol 18: $155-162$.

Carmichael, W. W., and J. An (1999) Using an enzyme immunosorbent assay (ELISA) and a protein phosphatase inhibition assay (PP1A) for the detection of microcystins and nodularins. Nat Toxins 7: 377-385.

Castenholz, R. W. 1988. Culturing methods for cyanobacteria. Methods Enzymol 167: 68-93.

Chorus, I., and J. Bartram (1999) Toxic Cyanobacteria in Water: A Guide to Their Public Health Consequences, Monitoring, and Management. London: E \& FN Spon.

Codd, G.A., C. J. Ward, and S. G. Bell (1997) Cyanobacterial toxins: occurrence, modes of action, health effects and exposure routes. In Applied Toxicology: Approaches Through Basic Science, Arch. Toxicol. Suppl. Seiler, J.P., and E., V. (eds). Berlin: Springer, pp. 399-410.

Cooney, R. P., O. Pantos, M. D. A. Le Tissier, M. R. Barer, A. G. O’Donnell, and J. C. Bythell (2002) Characterization of the bacterial consortium associated with black band disease in coral using molecular microbiological techniques. Environ Microbiol 4: 401413.

Dietrich D., and S. Hoeger (2005) Guidance values for microcystins in water and cyanobacterial supplement products (blue-green algal supplements): A reasonable or misguided approach? Toxicol Appl Pharmacol 203: 273-289.

Ducklow, H. W., and R. Mitchell (1979) Observations on naturally and artificially diseased tropical corals: a scanning electron microscopy study. Microb Ecol 5: 215-223. 
Falconer, I. R., and D. S. Yeung (1992) Cytoskeletal changes in hepatocytes induced by Microcystis toxins and their relation to hyperphosphorylation of cell proteins. Chem Biol Interact 81: 181-96.

Fisher, W. J., I. Garthwaite, C. O. Miles, K. M. Ross, J. B. Aggen, A. R. Chamberlin, N. A. Towers, and D. R. Dietrich (2001) Congener-independent immunoassay of microcystins and nodularins. Environ Sci Technol 35: 4849-4858.

Frias-Lopez, J., A. L. Zerkle, G. T. Bonheyo, and B. W. Fouke (2002) Partitioning of bacterial communities between seawater and healthy, black band diseased, and dead coral surfaces. Appl Environ Microbiol 68: 2214-2228.

Frias-Lopez, J., G. T. Bonheyo, Q. S. Jin, and B. W. Fouke (2003) Cyanobacteria associated with coral black band disease in Caribbean and Indo-Pacific Reefs. Appl Environ Microbiol 69: 2409-2413.

Frias-Lopez, J., J. S. Klaus, G. T. Bonheyo, and B. W. Fouke (2004) Bacterial community associated with black band disease in corals. Appl Environ Microbiol 70: $5955-5962$.

Gantar, M., R. Sekar, and L. L. Richardson (2009) Cyanotoxins from Black Band Disease of Corals and from Other Coral Reef Environments. Microb Ecol 58: 856-864.

Garrett, P., and H. Ducklow (1975) Coral diseases in Bermuda. Nature 253: 349-350.

Green, E.P., and A. W. Bruckner (2000) The significance of coral disease epizootiology for coral reef conservation. Biol Conserv 96: 347-361.

Guzman, R.E., and P. F. Solter (2002) Characterization of subletal MC-LR exposure in mice. Wet Pathol 39: 17-26.

Hughes, T. P., A. H. Baird, D. R. Bellwood, M. Card, S. R. Connolly, C. Folke, et al. (2003) Climate change, human impacts, and the resilience of coral reefs. Science 301: 929-933.

Jörgensen, B.B., Y. Cohen, and N. P. Revsbech (1986) Transition from anoxygenic to oxygenic photosynthesis in a Microcoleus chthonoplastes cyanobacterial mat. Appl Env Microbiol 51: 408-417.

Lankoff, A., A. Banasik, G. Obe, M. Deperas, K. Kuzminski, M. Tarczynska, T. Jurczak, and A. Wojcik (2003) Effect of microcystin-LR and cyanobacterial extract from Polish reservoir of drinking water on cell cycle progression, mitotic spindle, and apoptosis in CHO-K1 cells. Toxicology and Applied Pharmacology 189: 204-213. 
Lee, S. J., M. H. Jang, H. S. Kim, B. D. Yoon, and H. M. Oh (2000) Variation of microcystin content of Microcystis aeruginosa relative to medium N:P ration and growth stage. Appl Microbiol 89: 323-329.

Myers, J. L., R. Sekar, and L. L. Richardson (2007) Molecular detection of the cyanobacterial genera Geitlerinema and Leptolyngya in blacka band disease of corals. Appl Environ Microbiol 73: 5173-5182.

Nübel, U. F., F. Garcia-Pichel, and G. Muyzer (1997) PCR primers to amplify 16S rRNA genes from cyanobacteria. Appl Environ Microbiol 63: 3327-3332.

Oehrle, S.A., B. Southwell, and J. Westrick (in press) Detection of various freshwater cyanobacterial toxins using ultra-performance liquid chromatography tandem mass spectrometry. Toxicon.

Pandolfi, J. M., R. H. Bradbury, E. Sala, T. P. Hughes, K. A. Bjorndal, R. G. Cook, et al. (2003) Global trajectories of the long-term decline of coral reef ecosystems. Science 301: 955-958.

Ramos-Flores, T. (1983) Lower marine fungus associated with black line disease in star corals (Montastrea annularis). Biol Bull 165: 129-135.

Rasoulouniriana, D., N. Siboni, E. Ben-Dov, E. Kramarsky-Winter, Y. Loya, and A. Kushmaro (2009) Pseudoscillatoria coralii gen. nov., sp. nov., a cyanobacterium associated with coral black band disease (BBD). Dis Aquat Org 87: 91-96.

Richardson, L. L. (1996) Motility patterns of Phormidium corallyticum and Beggiatoa spp. associated with black band disease of corals. Microb Ecol 32: 323-335.

Richardson L. L., A. W. Miller, E. Broderick, L. Kaczmarsky, M. Gantar, D. Stanić, and R. Sekar (2009) Sulfide, microcystin, and the etiology of black band disease. Dis Aq Org 87: 79-90.

Richardson, L. L. (1998) Coral diseases: what is really known? Trends Ecol Evol 13: 438-443.

Richardson, L. L. (2004) Black band disease. In Coral health and disease, Rosenberg, E., and Loya, Y. (eds). Berlin: Springer-Veriag, pp. 325-349.

Richardson, L. L., and K. G. Kuta (2003) Ecological physiology of the black band disease cyanobacterium Phormidium corallyticum. FEMS Microbiol Ecol 43: 287-298.

Richardson, L. L., and R. W. Castenholz (1987) Enhanced survival of the cyanobacterium Oscillatoria terebriformis in darkness under anaerobic conditions. Appl Env Microbiol 53: 2151-2158. 
Richardson, L. L., K. G. Kuta, S. Schnell, and R. G. Carlton (1997) Ecology of the black band disease microbial consortium. Proceedings of the Eighth International Coral Reef Symposium 1: 597-600.

Richardson, L. L., R. Sekar, J. L. Myers, M. Gantar, J. D. Voss, L. Kaczmarsky, et al. (2007) The presence of the cyanobacterial toxin microcystin in black band disease of corals. FEMS Microbiol Lett 272: 182-187.

Rippka, R., J. Dervelles, J. B. Waterbury, M. Herdman, and R. Y. Stanier (1979) Generic assignments, strain histories and properties of pure cultures of cyanobacteria. $J$ Gen Microbiol 111: 1-61.

Rohrlack, T., and P. Hyenstrand (2007) Fate of intracellular microcystins in the cyanobacterium Microcystis aeruginosa (Chroococcales, Cyanophyceae). Phycologia 46: 277-283.

Rützler, K., D. L. Santavy, and A. Antonius (1983) The black band disease of Atlantic reef corals: III. Distribution, ecology and development. PSZNI Mat Ecol 4: 29-358.

Sekar, R., L. Kaczmarsky, and L. L. Richardson (2009) Effect of freezing on PCR amplification of the 16S rRNA gene from microbes associated with black band disease of corals. Appl Env Microbiol 75: 2581-2584.

Sekar, R., D. K. Mills, E. R. Remily, J. D. Voss, and L. L. Richardson (2006) Microbial communities in the surface mucopolysaccharide layer and the black band microbial mat of the black band-diseased Siderastrea siderea. Appl Environ Microbiol 72: 5963-5973.

Sussman, M., D. Bourne, and B. Willis. (2006) A single cyanobacterial ribotype is associated with both red and black bands on diseased corals from Palau. Dis Aquat Org 69: 111-118.

Sutherland, K.P., J. W. Porter, and C. Torres (2004) Disease and immunity in Caribbean and Indo-Pacific zooxanthellate corals. Mar Ecol Prog Ser 266: 273-302.

Taylor, D.L. (1983) The black band disease of Atlantic reef corals: II. Isolation, cultivation, and growth of Phormidium corallyticum. PSZNI Mar Ecol 4: 321-328.

Van der Westhuizen, A. K., and J. N. Eloff (1985) Effects of temperature and light on toxicity and growth of the blue-green alga Microcystis aeruginosa [UV-006]. Planta 163: $55-59$.

Viehman S., D. K. Mills, G. W. Meichel, and L. L. Richardson (2006) Culture and identification of Desulfovibrio spp. from black band disease of corals on reefs of Florida Keys and Dominica. Dis Aquat Organ 69: 119-127. 
Wiedner, C., P. M. Visser, J. Fastner, J. S. Metcalf, G. A. Codd, and L. R. Mur (2003) Effects of light on the microcystin content of Microcystis strain PCC 7806. Appl Environ Microbiol 69: 1475-1481.

Žegura, B., B. Sedmak, and M. Filipič (2003). Microcystin-LR induces oxidative DNA damage in human hepatoma cell line HepG2. Toxicon 41: 41-48. 
Table 1. BBD cyanobacterial isolates investigated in this study. Taxonomic identification was based on 16S rRNA gene sequencing.

\begin{tabular}{|l|l|l|l|}
\hline $\begin{array}{l}\text { Strain } \\
\text { designation }\end{array}$ & $\begin{array}{l}\text { Source (host coral, } \\
\text { reef, region and } \\
\text { sample date) }\end{array}$ & $\begin{array}{l}\text { GenBank accession no. } \\
\text { with reference }\end{array}$ & $\begin{array}{l}\text { Closest relative in } \\
\text { GenBank (GenBank accession } \\
\text { no) }\end{array}$ \\
\hline $100-1$ & $\begin{array}{l}\text { BBD on Siderastrea } \\
\text { siderea, } \\
\text { St. Croix, U.S. } \\
\text { Virgin Islands, } \\
\text { 6/2007 }\end{array}$ & $\begin{array}{l}\text { HM048872 } \\
\text { (This work) }\end{array}$ & $\begin{array}{l}\text { Oscillatoria } \text { sp. }^{1} \\
{\text { Pseudoscillatoria } \text { coralii }^{2}}^{2} \\
\text { BgP10_4S (FJ210722.2) }\end{array}$ \\
\hline $\begin{array}{l}\text { BBD on } \\
\text { Diploria strigosa, } \\
\text { St. Croix, U.S. } \\
\text { Virgin Islands, } \\
\text { 6/2007 }\end{array}$ & $\begin{array}{l}\text { EU743965.1 } \\
\text { (Myers and Richardson, } \\
\text { 2009) }\end{array}$ & $\begin{array}{l}\text { Oscillatoria } \text { sp. }^{1} \\
\text { Pseudoscillatoria coralii }^{2} \\
\text { BgP10_4S (FJ210722.2) }\end{array}$ \\
\hline
\end{tabular}

${ }^{1}$ Strains $100-1$ and $101-1$ were close matches (97-100\% sequence homology) to multiple black band disease cyanobacterial strains deposited as "uncultured cyanobacteria" in GenBank and identified as most closely related to Oscillatoria by phylogenetic analysis (Sekar et al., 2009). References to studies that detected this sequence include FriasLopez et al., 2003; Sussman et al., 2006; Barneah et al., 2007; Myers et al., 2007 and Sekar et al., 2008, 2009.

${ }^{2}$ This newly proposed cyanobacterial species was isolated from black band disease in the Red Sea (Rasoulouniriana et al., 2009). The 16S rRNA gene sequence is, by GenBank BLAST, 99\% similar to four strains deposited as "uncultured cyanobacteria" and shown to be most closely related to Oscillatoria by phylogenetic analysis (GenBank accession numbers referenced to Sekar et al. 2008, 2009) 
Table 2. Mean microcystin-LR equivalents produced in BBD cyanobacterial cultures based on cell extracts and ELISA. Experiments were run in triplicate and repeated three times.

\begin{tabular}{|c|c|c|}
\hline Isolate & $\begin{array}{c}\text { ELISA } \\
\left(\boldsymbol{\mu g} \text { MC-equivalent } \mathbf{~}^{-1}\right)\end{array}$ & References \\
\hline Oscillatoria $100-1$ & $0.17 \pm 0.009$ & This work \\
\hline Oscillatoria $101-1$ & $0.27 \pm 0.009$ & This work \\
\hline
\end{tabular}

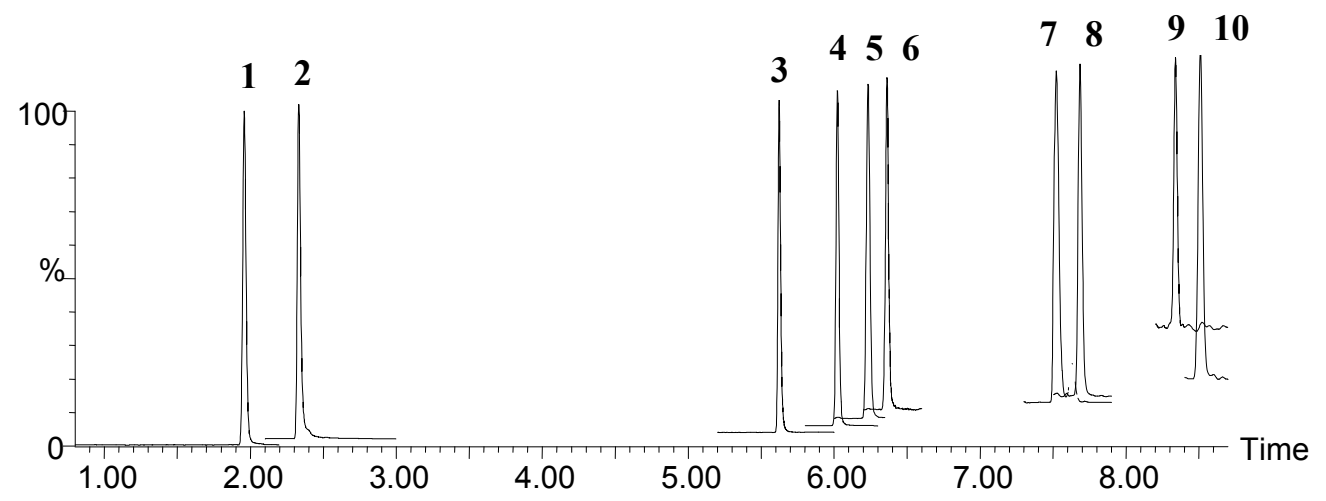

Figure 1. UPLC-MS/MS separation of a standard mix of cyanotoxins of interest. Peak identifications: (1) cylindrospermopsin, (2) anatoxin- $a$, (3) MC-RR, (4) nodularin, (5) MC-YR, (6) MC-LR, (7) MC-LA, (8) MC-LY, (9) MC-LW, and (10) MC-LF. 


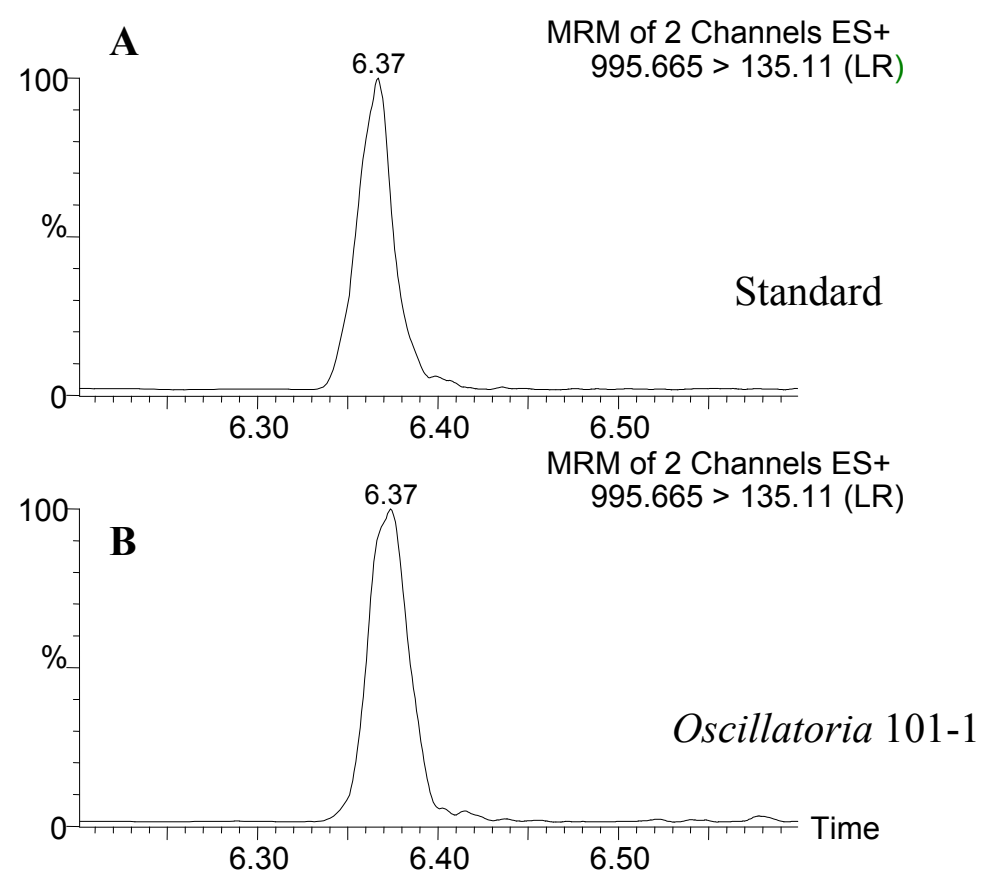

Figure 2. UPLC-MS/MS trace analysis of a cell extract of Oscillatoria strain 101-1 (B) showing a positive identification of MC-LR as compared to a standard (A) of purified MC-LR. 995>135 is the mass transition for MC-LR. 


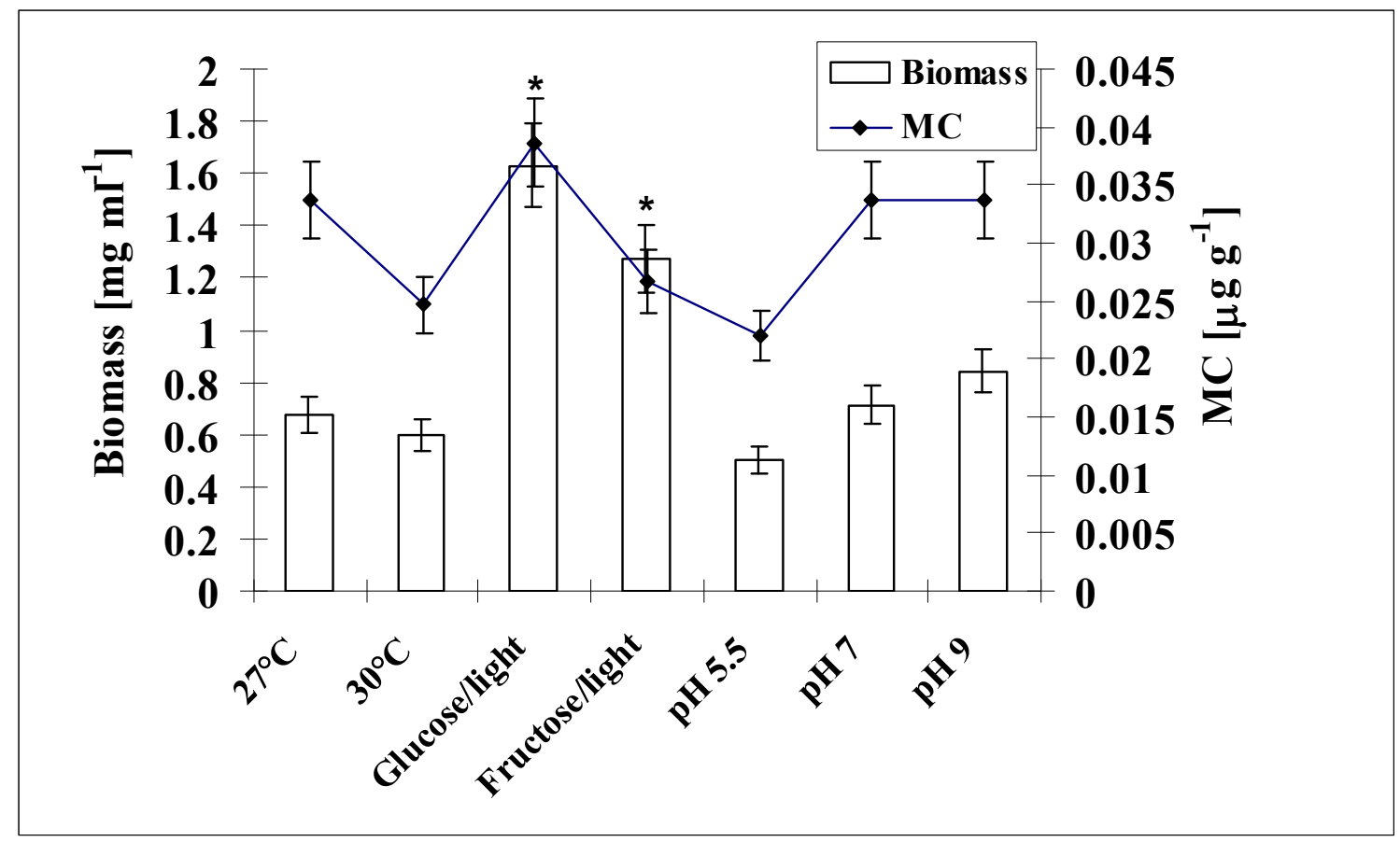

Figure 3. Effect of environmental factors on growth (bars) and production of MC-

equivalent (filled circles) by Oscillatoria strain 101-1. Statistical significance is indicated by * (biomass). Microcystin production was not significantly different for any culture condition. 


\title{
CHAPTER IV.
}

\section{IS OSCILLATORIA SP. THE PRIMARY PATHOGEN OF BLACK BAND DISEASE OF CORALS?}

\begin{abstract}
Black band disease (BBD) is one of the most important diseases contributing to coral decline worldwide. It is characterized as a dark colored band that migrates across a coral surface, killing healthy tissue and leaving behind dead coral skeleton. The mat is dominated by phycoerythrin-rich, gliding, filamentous non-heterocystous cyanobacteria. Although many members of this consortium have been identified, the primary pathogen is still unknown. Molecular methods have revealed that a $16 \mathrm{~S}$ rRNA sequence of one cyanobacterium, an Oscillatoria sp., is consistently found in BBD samples from various and distant geographical regions and different coral host species. This organism was not available in culture until now. Recently, two non-axenic strains of Oscillatoria sp. (strains 101-1 and 100-1) were isolated from two BBD infected coral host species, Diploria strigosa and Siderastrea siderea respectively. The aim of this study was to test the ability of these two strains to initiate BBD infection under controlled laboratory conditions. Results showed that when laboratory maintained apparently healthy coral fragments of Siderastrea siderea and Diploria strigosa were infected with Oscillatoria, both strains indeed caused infection, manifested by firm attachment of cyanobacterial filaments, formation of a lesion on the coral surface, and eventual lysis of coral tissue. An active sulfur cycle similar to that associated with naturally occurring BBD developed along with infection. Attempts to cause infection of corals using laboratory cultures of
\end{abstract}


other BBD cyanobacterial genera (Geitlerinema sp. and Leptolyngbya sp.) isolated from BBD were unsuccessful.

\section{Introduction}

During the last 30 years approximately $30 \%$ of corals worldwide have been lost as a result of coral reef degradation (Hughes et al., 2003; Harvell et al., 2007). This degradation includes effects of coral diseases, which are now recognized as a major cause for the decline of coral cover worldwide (Dustan, 1999; Porter et al., 2001). Of these, black band disease (BBD) is considered one of the most important coral diseases (Rosenberg and Loya, 2004) and affects at least 25 Caribbean and 45 Indo-Pacific coral species (Sutherland et al., 2004; Weil, 2004).

Black band disease is a horizontally migrating dark-colored band approximately 1 $\mathrm{mm}$ thick that ranges in width from $1 \mathrm{~mm}$ to a few centimeters. The band migrates across the surface of corals at a rate between $3 \mathrm{~mm}$ and $1 \mathrm{~cm} /$ day killing healthy tissue and leaving behind dead coral skeleton (Antonius, 1981; Richardson, 1996; Richardson, 1998). The rate of disease migration depends on different environmental factors that include elevated nutrients, temperature, and light intensity (Voss and Richardson, 2006; Boyett et al., 2007).

Black band disease consists of a pathogenic microbial consortium dominated by phycoerythrin-rich, gliding, filamentous non-heterocystous cyanobacteria (Rützler et al., 1983). The microbial consortium also contains sulfide-oxidizing bacteria (Garrett \& Ducklow, 1975; Ducklow \& Mitchell, 1979), sulfate reducing bacteria (Cooney et. al., 2002; Viehman et al., 2006), marine fungi (Ramos-Flores, 1983), and numerous heterotrophic bacteria (Cooney at al., 2002; Frias-Lopez et al., 2002; Frias-Lopez et al., 
2004; Sekar et al., 2006; Barneah et al., 2007). Although many members of the BBD mat have been identified using microscopic and molecular techniques, the identity of a primary pathogen is still unknown. To date suggested BBD primary pathogens have included cyanobacteria and several species of heterotrophic bacteria - however, Koch's Postulates have not been fulfilled for any of them.

Black band disease is dominated by cyanobacteria, which forms the physical matrix of the BBD mat. It was proposed (Rützler et al., 1983) that a BBD cyanobacterium Phormidium corallyticum (described based on morphology) was the primary pathogen, however no experimental evidence was provided and no cultures were obtained. Since that time molecular techniques have been used by several investigators to study cyanobacteria associated with BBD and it has been shown that more than one genus of BBD cyanobacteria is present. Denaturing gradient gel electrophoresis (DGGE) with universal bacterial 16S rRNA gene primers and amplified 16S rRNA gene restriction analysis of BBD clone libraries were used by Cooney at al. (2002) to characterize BBD samples from 11 coral colonies of the Caribbean species Diploria strigosa, Montastraea annularis, and Colpophyllia natans collected at St. Croix (US Virgin Islands) and Barbados. The results revealed a single cyanobacterial sequence common to all of the BBD samples, which was deposited as 'uncultured BBD Oscillatoria' (accession no. AF473936). The sequence was most similar (92\%) to Oscillatoria cf. coralline (accession no. X84812). Terminal restriction fragment length polymorphism (T-RFLP) and cloning and sequencing using cyanobacteria-specific primers were used by FriasLopez et al. (2003) to identify cyanobacteria present in 11 BBD samples from Curaçao (six colonies of Diploria strigosa, two colonies of Montastraea cavernosa, and one 
colony of Montastraea annularis) and New Britain, Papua New Guinea (two colonies of Porites lutea). One dominant cyanobacterial sequence was present in nine of the BBD samples from Curaçao. The 16S rRNA gene sequence for this cyanobacterium, which was designated CD1C11 (accession no. AY038527) was 98\% similar to that of the uncultured BBD Oscillatoria identified by Cooney at al. (2002). Sekar et al. (2006) also detected the presence of Oscillatoria in BBD. They analyzed the microbial community associated with BBD from two colonies of Siderastrea siderea in the Bahamas, using cloning and sequencing of the $16 \mathrm{~S}$ rRNA gene with universal bacterial primers. Sequencing results revealed the presence of three cyanobacterial sequences. Two of these sequences were $91 \%$ similar to that of Lyngbya hieronymusii var. hieronymusii (accession no. AB045906). The third cyanobacterial sequence was 93\% similar to that of the uncultured Oscillatoria (accession no. AF473936 deposited in the Cooney at al. (2002) study). Only one cyanobacterial ribotype associated with black and red bands on corals of Palau was reported by Sussman et al. (2006). This ribotype was $99 \%$ similar to that of the same Caribbean uncultured BBD Oscillatoria (accession no. AF473936). Myers et al. (2007) isolated cyanobacteria from 29 BBD samples collected from reefs located offshore of Key Largo (Florida), Lee Stocking Island (Bahamas), St. Croix (US Virgin Islands) and Negros Island, (Philippines) and confirmed the presence of the cyanobacterial isolates in the BBD community by using denaturing gradient gel electrophoresis (DGGE). Their DGGE results, obtained using cyanobacteria-specific 16S rRNA gene primers (GC-CYA359F and CYA781R(b)), revealed that the most common BBD cyanobacterial sequence, detected in 26 of the 29 BBD field samples, was again most closely related to that of the Oscillatoria sp. (accession no. AF473936). 
While molecular studies have revealed that Oscillatoria sp. is a consistent member of the BBD consortium, no studies have been carried out to examine its role in BBD because this organism was not available in culture until recently. Two strains of BBD Oscillatoria, designated 100-1 and 101-1 were isolated recently, and in the present study I assessed the ability of these two strains to initiate an infection on laboratory maintained coral fragments of the host corals Siderastrea siderea and Diploria strigosa.

\section{Materials and Methods}

\section{Experimental organisms}

Oscillatoria sp. strains 101-1 and 100-1 were isolated from BBD samples collected on a reef site in Frederiksted, St. Croix, U.S. Virgin Islands. Oscillatoria strain 101-1 was isolated from the coral Diploria strigosa and strain 100-1 was isolated from Siderastrea siderea. Samples were collected using sterile, needleless $10 \mathrm{ml}$ syringes while SCUBA diving. To isolate cyanobacteria from each sample the gliding method described by Castenholz (1988) was used, in which small pieces of BBD were point inoculated onto ASNIII and BG11 agar plates (Rippka et al., 1979). After 24 h, a dissecting microscope (Motic SMZ-140, Grasonville, MD, USA) was used to locate filaments that had glided out from the initial point of inoculation. Single cyanobacterial filaments were cut out of the agar surface using sterile watchmaker's forceps and transferred to tubes containing $10 \mathrm{ml}$ of liquid ASN III media. Laboratory (non-axenic) cultures were maintained on ASNIII and marine BG11 at $27^{\circ} \mathrm{C}$ and $30 \mu \mathrm{E} \mathrm{m}^{-2} \mathrm{~s}^{-1}$ under $24 \mathrm{~h}$ of constant cool-white light regime (Philips, F34T12/CW/RS/EW). 


\section{Infection of coral fragments with Oscillatoria spp.}

Oscillatoria sp. strains 101-1 and 100-1 were used to inoculate coral fragments of Siderastrea siderea and Diploria strigosa, obtained from FKNMS Key West Coral Nursery (Permit number FKNMS-2007-026). In addition to Oscillatoria two cyanobacterial strains (Geitlerinema sp. 1991 and Leptolyngbya sp. 102a-1), also isolated from BBD, were tested.

Coral fragments $(\mathrm{N}=30)$ approximately 4 to $5 \mathrm{~cm}$ in diameter were placed, after recovery from collection and acclimation, into $10 \mathrm{~L}$ aquaria. Five aquaria were used in each experimental setup, four for each cyanobacterial test strain plus one as a control. Each aquarium contained six coral fragments, three of Siderastrea siderea and three of Diploria strigosa. Fragments were maintained under a 12:12 h light:dark cool-white fluorescent light regime with an intensity of $33 \mu \mathrm{E} \mathrm{m}^{-2} \sec ^{-1}$ and temperature of $28^{\circ} \mathrm{C}$. Apparently healthy coral fragments $(\mathrm{N}=6)$ not exposed to cyanobacteria were used as controls.

To inoculate coral fragments, a clump of cyanobacterial filaments approximately $5 \mathrm{~mm}$ in diameter, from each laboratory culture, was gently placed on the surface of each coral fragment by sterile forceps. The sterile forceps were kept on the surface of the inoculated coral fragments, appressing the cyanobacteria inoculated to the surface for 24$48 \mathrm{~h}$. Each experiment was repeated three times.

\section{Scanning Electron Microscopy (SEM)}

Coral fragments were fixed in $2.5 \%$ glutaraldehyde and maintained at $4{ }^{\circ} \mathrm{C}$ until processing. After fixation fragments were dehydrated through a graded series of alcohol by placing them for 10 min in ethanol at concentrations of 20, 40, 60, 70, 90 (one wash 
each), and $100 \%$ (three washes). Fragments were then freeze fractured in liquid nitrogen and dried in a critical point dryer (Tousimis, Rockville, MD), after which they were affixed to an aluminum stub using carbon adhesive tape and were coated with palladium/gold using a sputter coater (SPI-Module, West Chester, PA). Fragments were viewed using a Joel JSM-5900 LV SEM at Florida International University.

\section{Results}

\section{Infection}

Both strains of Oscillatoria sp. (101-1 and 100-1) were capable of causing infection on both coral species (Figure 1 and Figure 2). Infection was manifested by firm attachment to the coral surface followed by formation of a lesion (cyanobacterial patch) which increased in size over the course of the experiment, eventually killing coral tissue. The initial cyanobacterial inoculum applied onto the surface of each coral fragment, increased in size during the course of experiment.

The two other cyanobacterial strains isolated from BBD (Geitlerinema sp. 1991 and Leptolyngbya sp. 102a-1) failed to cause infection (data not shown). For these experiments all inoculated cyanobacterial cultures failed to attach to the coral surface and apparently died (were not visible in the aquaria).

\section{Microscopy}

Light microscopy and SEM of the patches on the coral fragment surface revealed, in addition to Oscillatoria, the presence of other cyanobacteria (Figure 3). The most conspicuous were filaments identified morphologically as Spirulina and those of an unidentified cyanobacterium with filaments of $8 \mu \mathrm{m}$ in diameter. 
During the experiments an interesting phenomenon was observed. After infection the cyanobacterial lesions had a distinctive blackish/red appearance, a color which was very similar to what is normally observed for BBD infected corals in the field. However this appearance changed depending on the light/dark cycle. When inspected in the morning before the change to light, the surface of most of the lesions had a whitish appearance (Figure 4) which changed back to dark red/black after exposure to light for 1$2 \mathrm{~h}$. Examination of a sample of the whitish layer under the light microscope revealed the predominance of filaments resembling Beggiatoa (Figure 5). Energy dispersive X-ray microanalysis (EDS) of freeze-fractured filaments resembling Beggiatoa confirmed that granules within the cells contained sulfur (Figure 6).

\section{Discussion}

Almost 40 years after the first report was published on BBD (Antonius, 1973), two strains of a BBD cyanobacterium that are capable of initiating coral infection in controlled laboratory conditions were isolated and maintained in culture. The 16S rRNA gene sequences of the isolates are $99 \%$ homologous to that of the Oscillatoria sp. which is most commonly detected in BBD samples globally from distant geographical regions (Frias-Lopez et al., 2003; Sussman et al., 2006; Sekar et al., 2006; Myers et al., 2007; Rasoulouniriana et al., 2009). Experimental manipulation showed that the two strains of Oscillatoria sp. (101-1 and 100-1) were capable of initiating infections resembling that of in situ BBD, eventually leading to complete coral tissue lyses.

Infection by laboratory cultures of BBD Oscillatoria was not specific to the original coral host species. Specifically, Oscillatoria strain 101-1, which was isolated from the coral Diploria strigosa, was capable of infecting both Diploria strigosa and the 
coral species Siderastrea siderea from which Oscillatoria strain 100-1 originated. The same results were obtained using Oscillatoria strain 100-1.

In these experiments unialgal cultures of Oscillatoria were used for inoculation. Yet a relatively short period of time after initial infection (2-3 weeks), the lesions contained, in addition to Oscillatoria, other cyanobacterial species. One of the accompanying cyanobacteria, Spirulina, was easily recognizable. This cyanobacterium was described as a secondary colonizer of BBD in one of the earlier reports on BBD (Rützler et al., 1983). It can be hypothesized that the cyanobacteria other than Oscillatoria originated from the pool of microorganisms residing within the apparently healthy coral. These cyanobacteria were apparently present in the coral fragments before infection and can be considered to be part of the 'normal microflora' of the coral. For some reason they proliferate once Oscillatoria filaments start colonizing the coral surface. These findings are in agreement with the results of Klaus et al. (2007) who showed that BBD-associated cyanobacteria are commonly detected in healthy coral tissues.

Previous attempts to induce an infection on coral fragments with the BBD strain Geitlerinema sp. 1991 were not successful (L. Richardson, personal communication). In this study I confirmed that the same strain (Geitlerinema sp. 1991) and a second strain (BBD Leptolyngbya sp. 102a-1) were not able to initiate an infection.

Sato et al. (2009) showed that non-BBD cyanobacterial patches can precede the onset of BBD, in which case the cyanobacterial assemblage shifted from Blennothrix sp.affiliated to Oscillatoria sp. - affiliated sequnces. The Oscillatoria was similar to those reported by others worldwide (Cooney et al., 2002; Frias-Lopez et al., 2003; Sekar et al., 
2006; Myers and Richardson, 2009). However, to date there have been no reports of such cyanobacterial patches preceding Caribbean BBD.

The Oscillatoria strains investigated in this work apparently possess unique features that allow initiation and maintenance of a BBD infection. It appears that the BBD Oscillatoria has an exceptional ability to firmly adhere to the coral surface, including the coral surface mucopolysaccharide layer (SML), and to resist coral protective mechanisms such as dislodging particulate matter and pathogenic microorganisms (Brown and Bythell, 2005; Abey and Santavy, 2006). At this point it can only be hypothesized that, because of this feature, BBD Oscillatoria can settle on a coral and form a physical matrix that then provides a suitable biological environment for the growth and proliferation of other members of the complex BBD consortium.

In addition to Oscillatoria and the other cyanobacteria, another conspicuous BBD member, Beggiatoa sp., was observed within the laboratory induced infection. The identification of Beggiatoa within the lesion is based solely on morphology and detection of intracellular sulfur-containing granules using SEM coupled with EDS analysis. Because of the presence of sulfide-oxidizing bacteria there is an active sulfur cycle within the lesion. As sulfide oxidizers, Beggiatoa sp. typically occupy the micronenvironment of an oxygen/sulfide interface, shown to be present in BBD (Carlton and Richardson, 1995). Such interfaces migrate vertically dependent on light, and it is well known that populations of Beggiatoa will migrate along with the interface. In the case of the laboratory induced BBD lesions it was observed, over the course of the experiments, that during the dark cycle when the oxic/anoxic interface was close to the surface Beggiatoa spp. formed a white layer on the surface of the mat. Shortly after the light cycle began the 
white layer disappeared, indicating vertical migration of Beggiatoa spp. into the BBD mat, accompanied by the migration of BBD Oscillatoria spp. to the surface. Interestingly, while Beggiatoa has been observed macroscopically and microscopically in many BBD samples (Garrett \& Ducklow, 1975; Ducklow \& Mitchell, 1979; Richardson, 1996; Viehman and Richardson, 2002), Beggiatoa sequences have proven to be very difficult to detect using molecular studies. In all BBD molecular studies to date a Beggiatoa related sequence has been detected only once (Sekar et al., 2008). The current study showed that Beggiatoa most likely resides in small numbers within healthy corals and can join the BBD microbial community as an 'opportunistic pathogen' once the developing cyanobacterial mat provides favorable conditions for its growth.

The increased incidence of coral diseases worldwide has led to rapidly expanding research in this field (Sokolow, 2009). Potential pathogens are still unknown for most of the coral diseases. Of the seven most commonly found coral diseases for which potential pathogens have been identified, Koch's postulates have been fulfilled for only five (Harvell et al., 2007). In this work it was not possible to perform the first step of Koch's postulates since heterotrophic bacteria grow within the polysaccharide matrix of the cyanobacterial sheath. I was, however, able to infect apparently healthy coral and reisolate Oscillatoria from the infected coral. As pointed out by Sokolow (2009), multifactorial etiology such as that for BBD, renders Koch's postulates impossible to apply.

Modern medicine recognizes that some diseases require multiple factors to produce disease signs. Black band disease appears to be a disease that is not only multimicrobial but multifactorial as well (Sokolow, 2009). This fact makes it challenging 
to answer the question 'Is Oscillatoria sp. a primary pathogen of black band disease?' In conclusion, at this point it appears that Oscillatoria sp. is the BBD cyanobacterium capable of colonizing corals and of forming a lesion which is an initial step in the development and progression of BBD. 


\section{REFERENCES}

Aeby, G. S., and D. L. Santavy (2006) Factors affecting susceptibility of the coral Montastrea faveolata to black band disease. Mar Ecol Prog Ser 318: 103-110.

Antonius, A. (1973) New observations on coral destruction in reefs. 10th Meeting Association of Island Marine Laboratories of the Caribbean 10: 3.

Antonius, A. (1981) The 'band' diseases in coral reefs. Proceedings of the Fourth International Coral Reef Symposium 2: 7-14.

Barneah, O., E. Ben-Dov, E. Kramarsky-Winter, and A. Kushmaro (2007)

Characterization of black band disease in Red Sea stony corals. Environ Microbiol 9: 1995-2006.

Boyett, H.V., G. Bourne, and B. L. Willis (2007) Elevated temperature and light enhance progression and spread of black band disease on staghorn corals of the Great Barrier Reef. Mar Biol 151: 1711-1720.

Brown, B. E., and J. C. Bythell (2005) Perspectives on mucus secretion in reef corals. Mar Ecol Prog Ser 296: 291-309.

Carlton, R.G., and L. L. Richardson (1995) Oxygen and sulfide dynamics in horizontally migrating cyanobacterial mat: black band disease of corals. FEMS Microbiol Ecol 18: $155-162$.

Castenholz, R.W. (1988) Culturing methods for cyanobacteria. Methods Enzymol 167: 68-93.

Cooney, R.P., O. Pantos, M. D. A. Le Tissier, M. R. Barer, A. G. O’Donnell, and J. C. Bythell (2002) Characterization of the bacterial consortium associated with black band disease in coral using molecular microbiological techniques. Environ Microbiol 4: 401413.

Ducklow, H.W., and R. Mitchell (1979) Observations on naturally and artificially diseased tropical corals: a scanning electron microscopy study. Microb Ecol 5: 215-223.

Dustan, P. (1999) Coral reefs under stress:sources of mortality in the Florida Keys. Nat Res Forum 23: 147-155.

Frias-Lopez, J., A. L. Zerkle, G. T. Bonheyo, and B. W. Fouke (2002) Partitioning of bacterial communities between seawater and healthy, black band diseased, and dead coral surfaces. Appl Environ Microbiol 68: 2214-2228. 
Frias-Lopez, J., G. T. Bonheyo, Q. S. Jin, and B. W. Fouke (2003) Cyanobacteria associated with coral black band disease in Caribbean and Indo-Pacific Reefs. Appl Environ Microbiol 69: 2409-2413.

Frias-Lopez, J., J. S. Klaus, G. T. Bonheyo, and B. W. Fouke (2004) Bacterial community associated with black band disease in corals. Appl Environ Microbiol 70: 5955-5962.

Garrett, P., and H. Ducklow (1975) Coral diseases in Bermuda. Nature 253: 349-350.

Harvell, D., E. Jordan-Dahlgren, S. Merkel, L. Raymundo, G. Smith, E. Weil, and B. Willis (2007) Coral disease, environmental drivers, and the balance between coral and microbial associates. Oceanography 20: 172-195.

Hughes, T.P., A. H. Baird, D. R. Bellwood, M. Card, S. R. Connolly, C. Folke, R. Grosberg, O. Hoegh-Guldberg, J.B.C. Jackson, J. Kleypas, J. M. Lough, P. Marshall, M. Nyström, S. R. Palumbi, J. M. Pandolfi, B. Rosen, and J. Roughgarden (2003) Climate change, human impacts, and the resilience of coral reefs. Science 301: 929-933.

Klaus J. S., I. Janse, J. M. Heikoop, R. A. Sanford, and B. W. Fouke (2007) Coral microbial communities, zooxanthellae and mucus along gradients of seawater depth and coastal pollution. Environ Microbiol 9: 1291-1305.

Myers, J.L., R. Sekar, and L. L. Richardson (2007) Molecular detection of the cyanobacterial genera Geitlerinema and Leptolyngya in blacka band disease of corals. Appl Environ Microbiol 73: 5173-5182.

Myers, J.L., and L. L. Richardson (2009) Adaptation of cyanobacteria to the sulfide-rich microenvironment of black band disease of coral. FEMS Microbiol Ecol 67: 242-251.

Porter, J.W., P. Dustan, W. C Jaap, K. L. Patterson, V. Kosmynin, O. W. Meier, M. E. Patterson, and M. Parsons (2001) Patterns of spread of coral disease in the Florida Keys. Hydrobiologia 460: 1-24.

Ramos-Flores, T. (1983) Lower marine fungus associated with black line disease in star corals (Montastrea annularis). Biol Bull 165: 129-135.

Rasoulouniriana, D., Siboni, N., Ben-Dov, E., Kramarsky-Winter, E., Loya, Y., and Kushmaro, A. (2009) Pseudoscillatoria coralii gen. nov., sp. nov., a cyanobacterium associated with coral black band disease (BBD). Dis Aquat Organ 87: 91-96.

Richardson, L.L. (1996) Motility patterns of Phormidium corallyticum and Beggiatoa spp. associated with black band disease of corals. Microb Ecol 32: 323-335. 
Richardson, L.L. (1998) Coral diseases: what is really known? Trends Ecol Evol 13: 438443.

Rippka, R., J. Dervelles, J. B. Waterbury, M. Herdman, and R. Y. Stanier (1979) Generic assignments, strain histories and properties of pure cultures of cyanobacteria. $J$ Gen Microbiol 111: 1-61.

Rosenberg, E. and Y. Loya. (2004) Coral health and disease. Springer-Verlag, Berlin, Germany.

Rützler, K., D.L. Santavy, and A. Antonius (1983) The black band disease of Atlantic reef corals: III. Distribution, ecology and development. PSZNI Mat Ecol 4: 29-358.

Sato, Y., B. L. Willis, and D. G. Bourne (2009) Successional changes in bacterial communities during the development of black band disease on the reef coral, Montipora hispida. ISME, 1-12.

Sekar, R., D. K. Mills, E. R. Remily, J. D. Voss, and L. L. Richardson (2006) Microbial communities in the surface mucopolysaccharide layer and the black band microbial mat of the black band-diseased Siderastrea siderea. Appl Environ Microbiol 72: 5963-5973.

Sekar, R., L. T. Kaczmarsky, and L. L. Richardson (2008) Microbial community composition of black band disease on the coral host Siderastrea siderea from three regions of the wider Caribbean. Mar Ecol Prog Ser 362:85-98.

Sokolow, S. (2009) Effects of a changing climate on the dynamics of coral infectious disease: a review of the evidence. Dis Aquat Organ 87: 5-18.

Sussman, M., D. G. Bourne, and B. L. Willis (2006) A single cyanobacterial ribotyp is associated with both red and black bands on diseased corals from Palau. Dis Aquat Organ 69: 111-118.

Sutherland, K.P., J. W. Porter, and C. Torres (2004) Disease and immunity in Caribbean and Indo-Pacific zooxanthellate corals. Mar Ecol Prog Ser 266: 273-302.

Viehman, T. S., D. K. Mills, G. W. Meichel, and L. L. Richardson (2006) Culture and identification of Desulfovibrio spp. From black band disease of corals on reefs of Florida Keys and Dominica. Dis Aquat Organ 69: 119-127.

Viehman, T. S., and L. L. Richardson. 2002. Motility patterns of Beggiatoa and Phormidium corallyticum in black band disease. In M. K. Moosa, S. Soemodihardjo, A. Soegiarto, K. Romimohtarto, A. Nontji, Soekarno, and Suharsono (eds.), Proceedings of the Ninth International Coral Reef Symposium 2: 1251-1255. 
Voss, J.D., and L. L. Richardson (2006) Coral diseases near Lee Stocking Island, Bahamas: patterns and potential drivers. Dis Aquat Organ 69: 33-40.

Weil, E. 2004. Coral reef diseases in the wider Caribbean. In Coral Health and Disease, E. Rosenburg and Y. Loya (Eds). Springer-Verlag, Berlin, 35-67. 

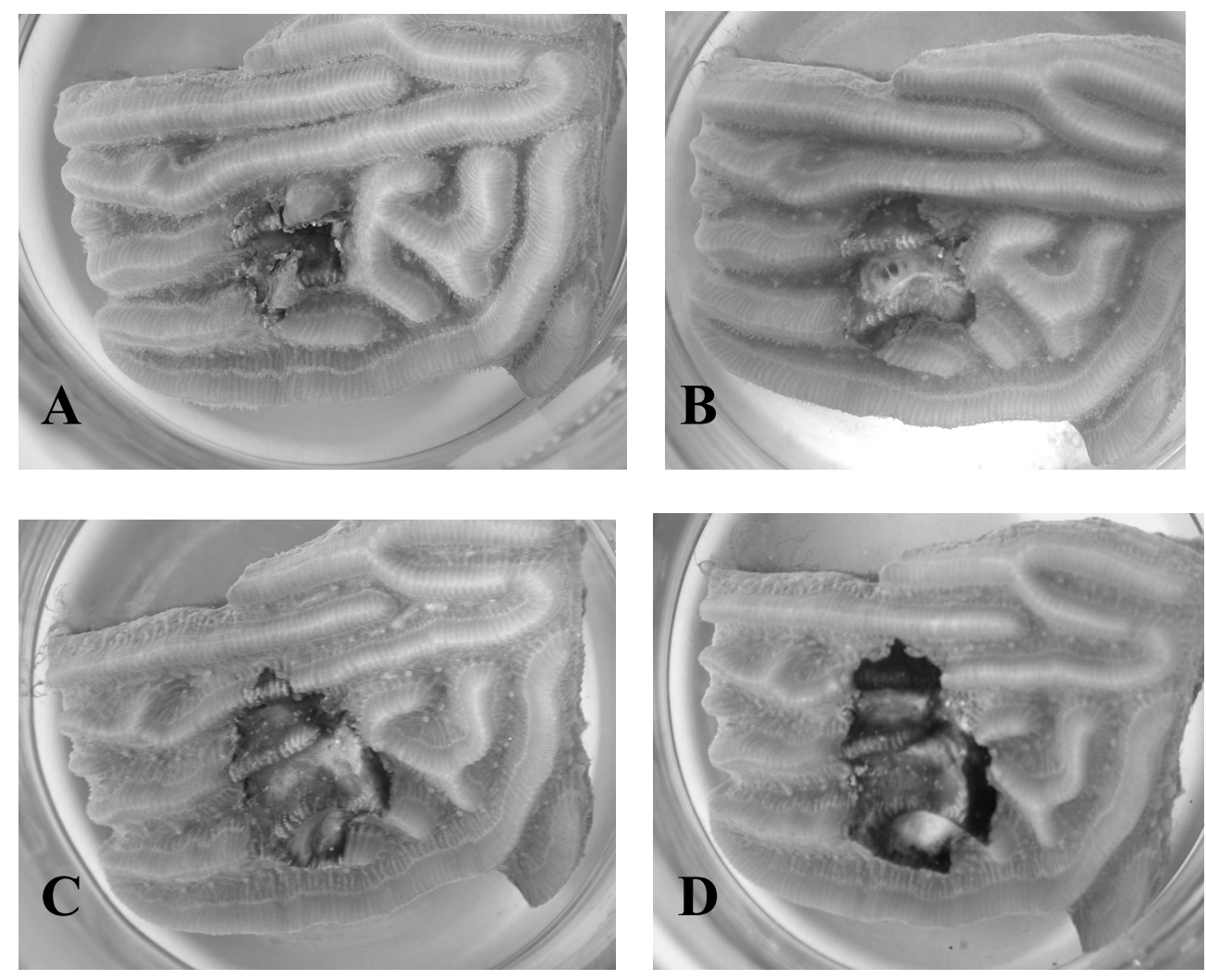

Figure 1. Oscillatoria strain 101-1 on a coral fragment of Diploria strigosa.

(A) $\mathrm{t}($ time $)=7 \mathrm{~d}$ (days). (B) $\mathrm{t}=14 \mathrm{~d}$. (C) $\mathrm{t}=21 \mathrm{~d}$. (D) $\mathrm{t}=28$. 

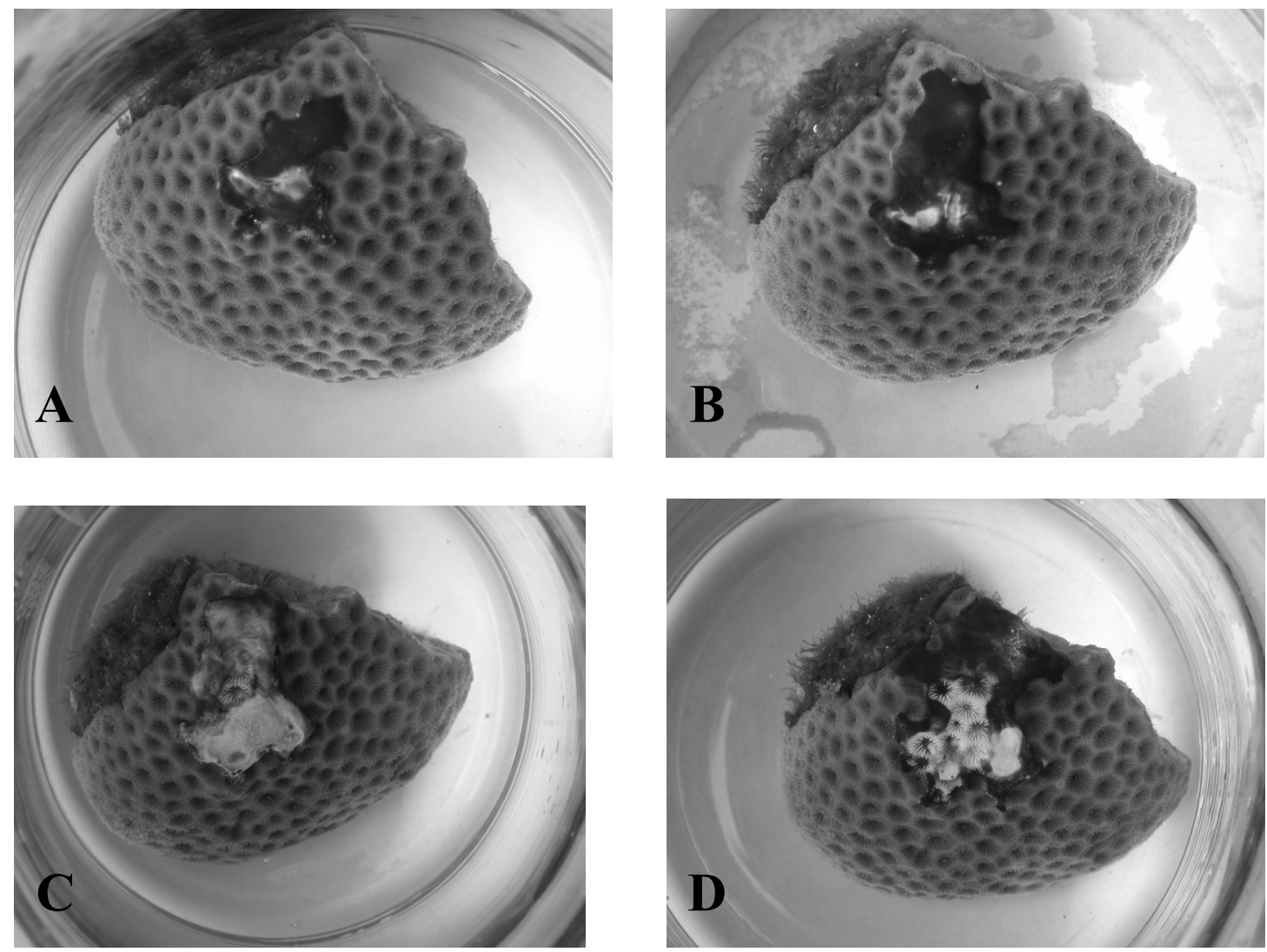

Figure 2. Oscillatoria strain 100-1 on a coral fragment of Siderastrea siderea. (A) t (time) $=7 \mathrm{~d}$ (days). (B) $\mathrm{t}=14 \mathrm{~d}$. (C) $\mathrm{t}=21 \mathrm{~d}$. (D) $\mathrm{t}=28 \mathrm{~d}$ ( Note the exposed coral skeleton in the middle). 

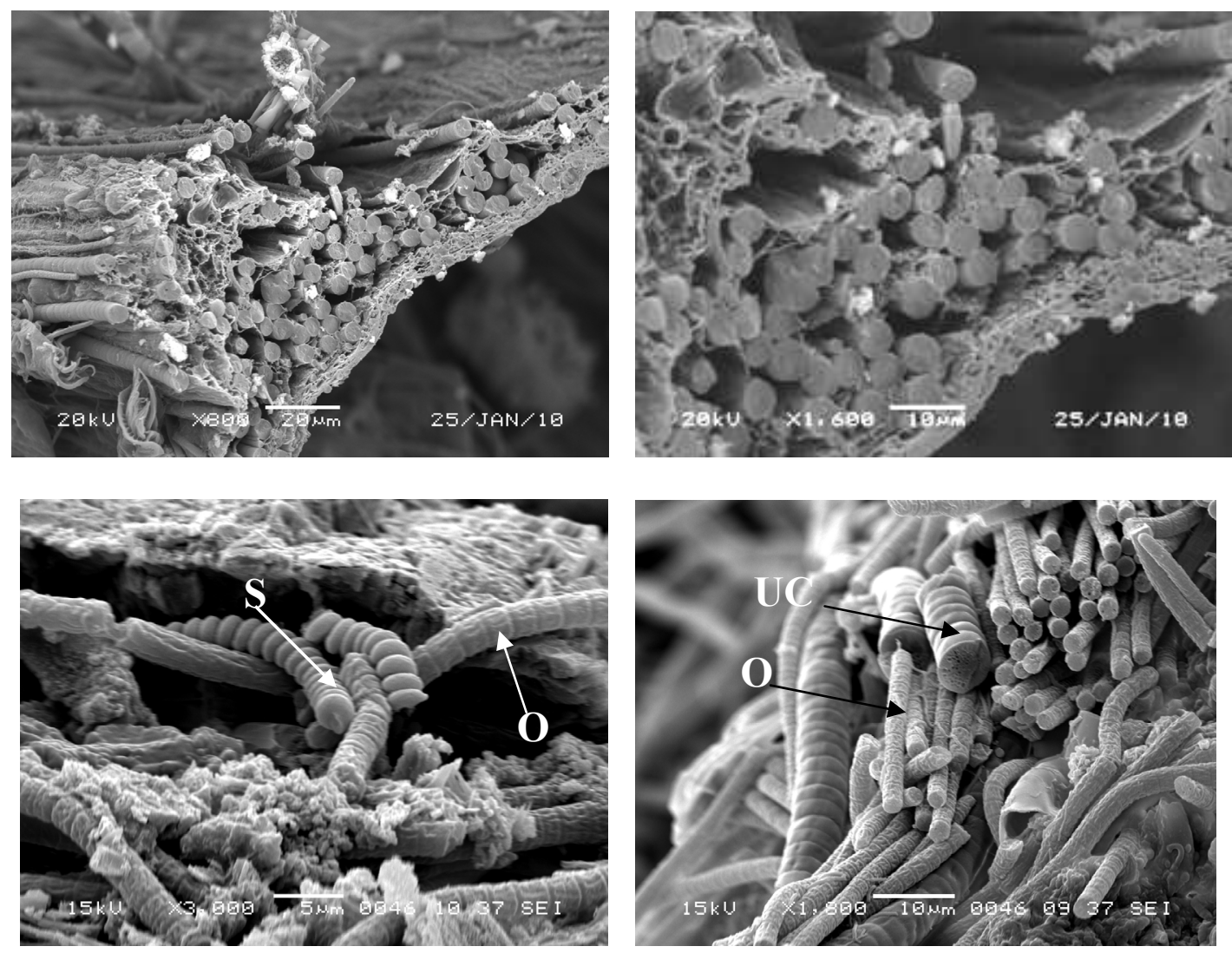

Figure 3. SEM of a freeze fractured fragment of Siderastrea siderea showing microbial growth three weeks after infection with Oscillatoria strain 100-1. (A) - a well defined layer consisting of filamentous organisms which run in the same direction; (B) - the base of the layer consists of mucilaginous fibers and smaller filaments; (C) - filaments of Spirulina and Oscillatoria (D) - filaments of large unidentified cyanobacteria can be seen among the filaments of Oscillatoria $(\mathrm{O}=$ Oscillatoria $; \mathrm{S}=$ Spirulina $; \mathrm{UC}=\mathrm{Unknown}$ cyanobacterium). 

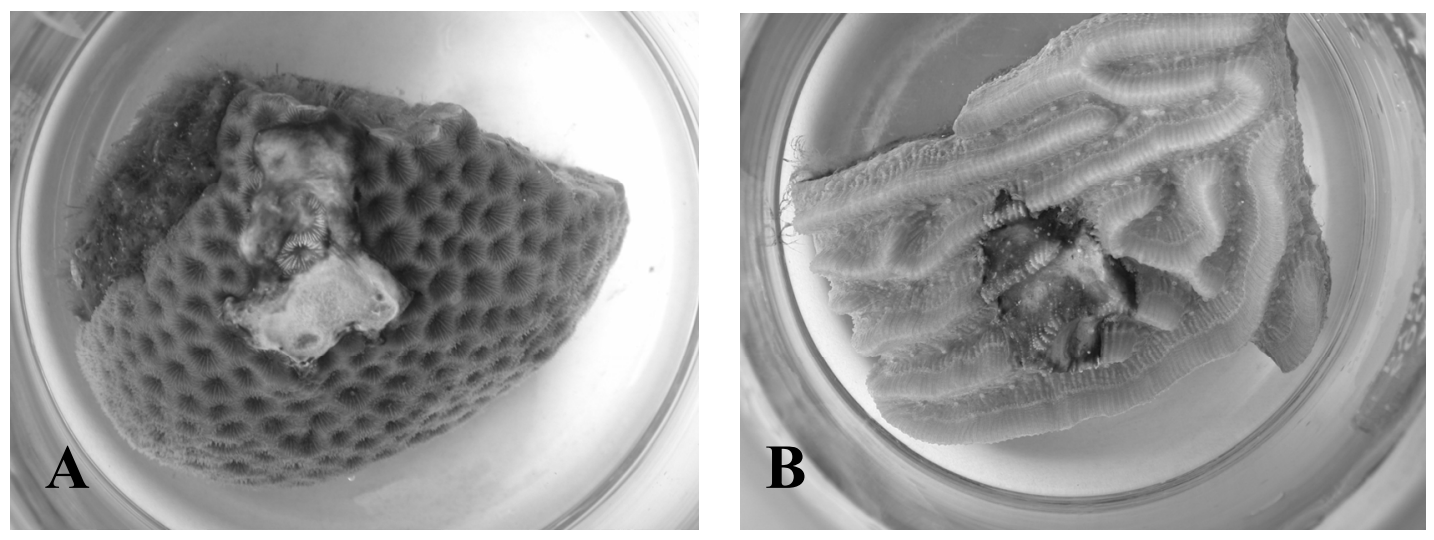

Figure 4. White appearance of the cyanobacterial patch seen during and after the dark cycle was presumably formed by species from the genus Baggiatoa. Coral fragment of (A) Siderastrea siderea infected with Oscillatoria strain 100-1 and (B) Diploria strigosa infected with Oscillatoria strain 101-1. 


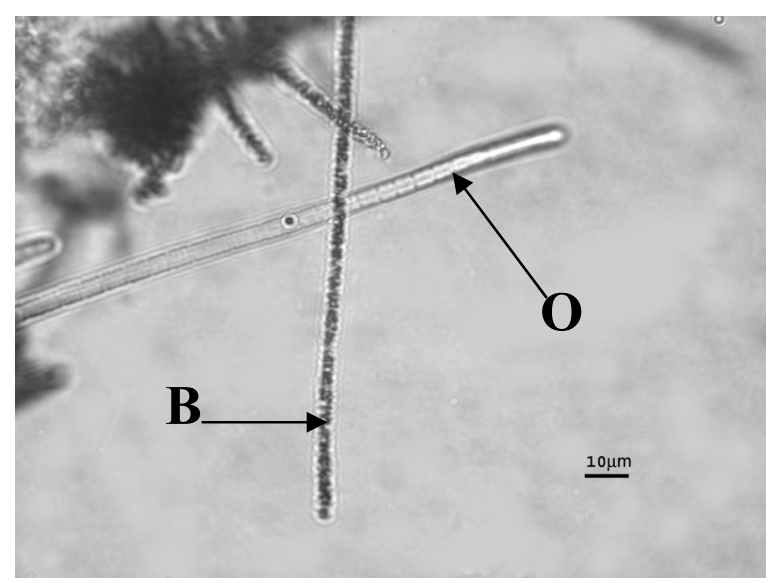

Figure 5. Photomicrograph of filaments of Beggiatoa sp. and Oscillatoria sp. in the patch formed after infection with Oscillatoria strain 100-1. The sample was taken at the beginning of the light cycle. Observe the numerous sulfur granules in Beggiatoa. $(\mathrm{O}=$ Oscillatoria $; \mathrm{B}=$ Beggiatoa $)$
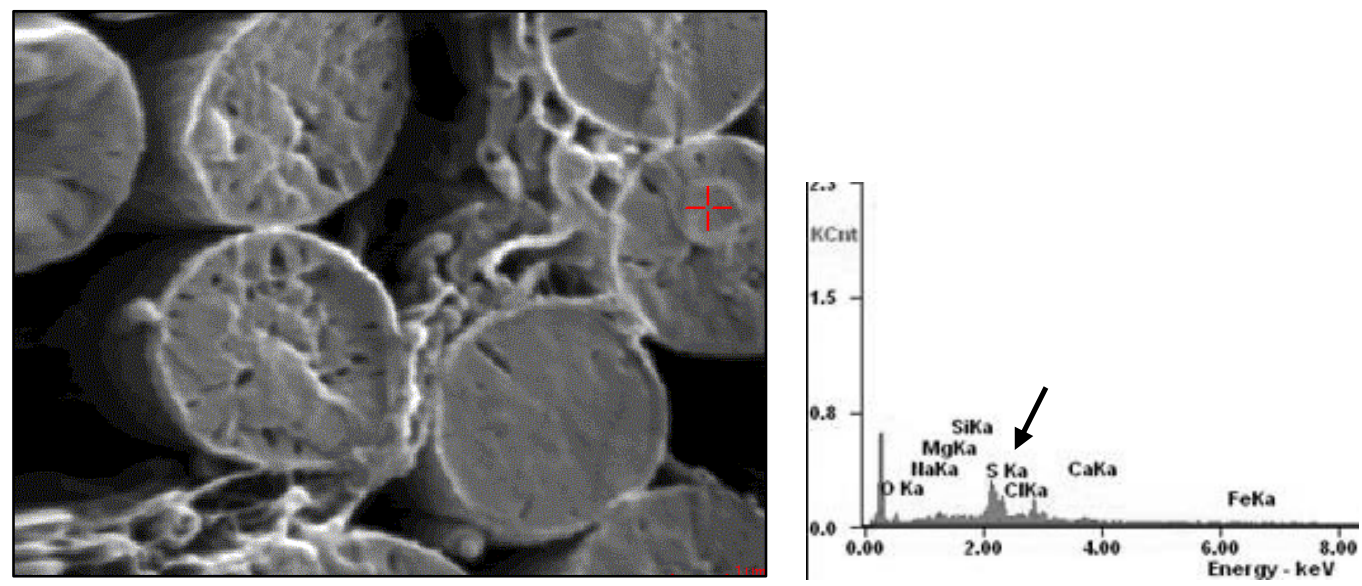

Figure 6. Back scatter image of filamentous microorganisms within cyanobacterial patch. (A) Energy dispersive X-ray analysis (EDS) was performed on the granular structure (indicated with + ) within the filament resembling Beggiatoa. (B) EDS spectrum showing the peak for sulfur (arrow). 


\section{CHAPTER V.}

\section{Conclusions}

The focus of this thesis was the characterization of two strains of cyanobacteria, Oscillatoria strains 101-1 and 100-1 that were isolated from BBD on two infected coral hosts, Diploria strigosa and Siderastrea siderea respectively. Sequences corresponding to this specific cyanobacterium have been reported as present in BBD samples from various and distant geographical regions that include the wider Caribbean, the IndoPacific, the Great Barrier Reef, the Red Sea, and the Philippines (Cooney et al., 2002; Frias-Lopez et al., 2003; Sekar et al., 2006; Myers et al., 2007; Sato et al; 2009), but the cyanobacterium was not available in culture until recently. Although many members of the pathogenic $\mathrm{BBD}$ microbial consortium have been identified, the primary pathogen is still unknown. In addition to characterizing BBD Oscillatoria sp. an aim of this study was to assess its role as a potential primary pathogen in BBD formation and progression.

As presented in chapter II, both strains were morphologically similar and were characterized as motile, unbranched, filamentous, non-heterocystous, and with one tapered and one rounded end cell for the filaments. Phycoerythrin was the dominant lightharvesting pigment. Trichomes were $3.5 \mu \mathrm{m}$ wide, with cells $3.5 \mu \mathrm{m}$ long. The TEM of a trichome cross-section revealed the presence of a radial thylakoid arrangement characteristic of members of the genus Phormidium. Trichomes were surrounded by a thick mucus layer which differed in appearance between the two strains. Optimal $\mathrm{pH}$ for growth was between 6 and 8 .

At lower $\mathrm{pH}$ the Oscillatoria cultures tended to form clumps, which may be significant in BBD etiology since the surface of the coral host (mucus) is acidic. The 
formation of clumps, which formed in both the light and dark, was unique for the Oscillatoria strains when compared to other cyanobacteria isolated from BBD. This phenomenon might be important in the initial phase of infection.

Chapter II included a phylogenetic analysis based on sequencing of the $16 \mathrm{~S}$ rRNA gene. However, because of the state of flux of cyanobacterial taxonomy, and as stated in chapter II, additional molecular analyses are needed to determine the final taxonomic placement of these isolates since the strains can be identified either as species of Oscillatoria or Phormidium according to Anagnostidis and Komarek (1988).

Chapter III addressed the pathogenicity of BBD, which is not yet well understood. It is known that multiple mechanisms are involved. Sulfide and anoxia are factors that have been demonstrated to contribute to pathogenicity and shown to cause coral tissue lysis (Richardson et al., 1997). Additionally, the cyanotoxin microcystin, detected in BBD samples and in cultures of BBD cyanobacteria, has been shown to cause coral tissue lysis and degradation (Richardson et al. 2007; Gantar et al. 2009). In chapter III the results of a study on cyanotoxin production are presented. Both Oscillatoria strains were capable of toxin production and both produced the variant microcystin-LR. Additionally, MC-LR production was assessed for Oscillatoria strain 101-1 under different environmental conditions. This strain was chosen because it produced higher amount of toxin in comparison to the strain 100-1. Results showed that microcystin production by strain 101-1 was not significantly affected by any of the environmental conditions tested, which is a different and potentially ecologically important, pattern when compared to other microcystin-producing BBD cyanobacteria. 
The toxin production and identification described in chapter III served as a background for the infection studies described in chapter IV. The aim of this work was to test the ability of the two Oscillatoria strains to initiate BBD infection under controlled laboratory conditions. Results revealed that both strains were capable of starting an infection resembling that of $\mathrm{BBD}$, which resulted in eventual complete coral tissue lysis. The Oscillatoria strains investigated appear to initiate and maintain a BBD infection by providing a physical matrix and suitable biological environment for growth and proliferation of other members of the polymicrobial BBD, including development of a sulfuretum (active sulfur cycle) that is found in naturally occurring BBD. Two other cyanobacterial strains isolated from BBD, Geitlerinema sp. 1991 and Leptolyngbya sp. 102a-1 were also tested for infectivity of corals. Both failed to cause infection. Results presented in Chapter IV therefore indicate that Oscillatoria may play an important role in the initiation and progression of BBD. 


\section{REFERENCES}

Anagnostidis, K., and J. Komarek (1988) Modern approach to the classification system of the cyanophytes. 3. Oscillatoriales. Arch Hydrobiol Algol Stud 50-53, 327-472.

Cooney, R.P., O. Pantos, M. D. A. Le Tissier, M. R. Barer, A. G. O’Donnell, and J. C. Bythell (2002) Characterization of the bacterial consortium associated with black band disease in coral using molecular microbiological techniques. In Environ Microbiol pp.401-413.

Frias-Lopez, J., G. T. Bonheyo, Q. S. Jin, and B. W. Fouke (2003) Cyanobacteria associated with coral black band disease in Caribbean and Indo-Pacific Reefs. Appl Environ Microbiol 69, 2409-2413.

Gantar, M., R. Sekar, and L. L. Richardson (2009) Cyanotoxins from Black Band Disease of Corals and from Other Coral Reef Environments. Microb Ecol 58, 856-864.

Myers, J.L., R. Sekar, and L. L. Richardson (2007) Molecular detection of the cyanobacterial genera Geitlerinema and Leptolyngya in blacka band disease of corals. Appl Environ Microbiol 73, 5173-5182.

Richardson, L.L., K.G. Kuta, S. Schnell, and R.G. Carlton (1997) Ecology of the black band disease microbial consortium. p 597-600 In H A Lessions and I G Macintyre (ed), Proceedings of the 8th International Coral Reef Symposium, Smithsonian Tropical Research Institute, Balboa, Panama.

Richardson, L.L., R. Sekar, J. L. Myers, M. Gantar, J. D. Voss, L. Kaczmarsky, E. R. Remily, G. L. Boyer, and P. V. Zimba (2007) The presence of the cyanobacterial toxin microcystin in black band disease of corals. FEMS Microbiol Lett 272, 182-187.

Sekar, R., D. K. Mills, E. R. Remily, J. D. Voss, and L. L. Richardson (2006) Microbial communities in the surface mucopolysaccharide layer and the black band microbial mat of the black band-diseased Siderastrea siderea. Appl Environ Microbiol 72, 5963-5973. 